Prepared in cooperation with the North Platte Natural Resources District

Quantifying Canal Leakage Rates Using a Mass-Balance Approach and Heat-Based Hydraulic Conductivity Estimates in Selected Irrigation Canals, Western Nebraska, 2007 through 2009

Scientific Investigations Report 2010-5226 


\section{Front cover:}

Background, Looking upstream from the Interstate Canal near Mintle, Nebraska streamflow-gaging station. Photograph by Michael Anderson, U.S. Geological Survey.

\section{Back cover:}

Top left, Acoustic Doppler current profiler measuring canal discharge, Interstate Canal, June, 2007.

Photograph by Michael Anderson, U.S. Geological Survey.

Top right, Stilling well installation, Interstate Canal, March, 2008. Photograph by Christopher Hobza, U.S.

Geological Survey.

Top right, Irrigation map of western Nebraska (Darton, 1903b, pl. 40). 


\section{Quantifying Canal Leakage Rates Using a Mass-Balance Approach and Heat- Based Hydraulic Conductivity Estimates in Selected Irrigation Canals, Western Nebraska, 2007 through 2009}

By Christopher M. Hobza and Michael J. Andersen

Prepared in cooperation with the North Platte Natural Resources District

Scientific Investigations Report 2010-5226 


\section{U.S. Department of the Interior \\ KEN SALAZAR, Secretary \\ U.S. Geological Survey \\ Marcia K. McNutt, Director}

U.S. Geological Survey, Reston, Virginia: 2010

This and other USGS information products are available at http://store.usgs.gov/
U.S. Geological Survey
Box 25286 , Denver Federal Center
Denver, CO 80225
To learn about the USGS and its information products visit http://www.usgs.gov/
1-888-ASK-USGS

Any use of trade, product, or firm names is for descriptive purposes only and does not imply endorsement by the U.S. Government.

Although this report is in the public domain, permission must be secured from the individual copyright owners to reproduce any copyrighted materials contained within this report.

Suggested citation:

Hobza, C.M., and Andersen, M.J., 2010, Quantifying canal leakage rates using a mass-balance approach and heatbased hydraulic conductivity estimates in selected irrigation canals, western Nebraska, 2007 through 2009: U.S. Geological Survey Scientific Investigations Report 2010-5226, 45 p. 


\section{Acknowledgments}

The authors thank managers Ron Cacek, North Platte Natural Resources District, Kevin Adams, Farmers Irrigation District, and Dennis Strauch, Pathfinder Irrigation District, for providing field support during data collection. The authors also thank Scott Schaneman and Thad Kuntz of the North Platte Natural Resources District for their help with installation and data collection. 
Blank Page 


\section{Contents}

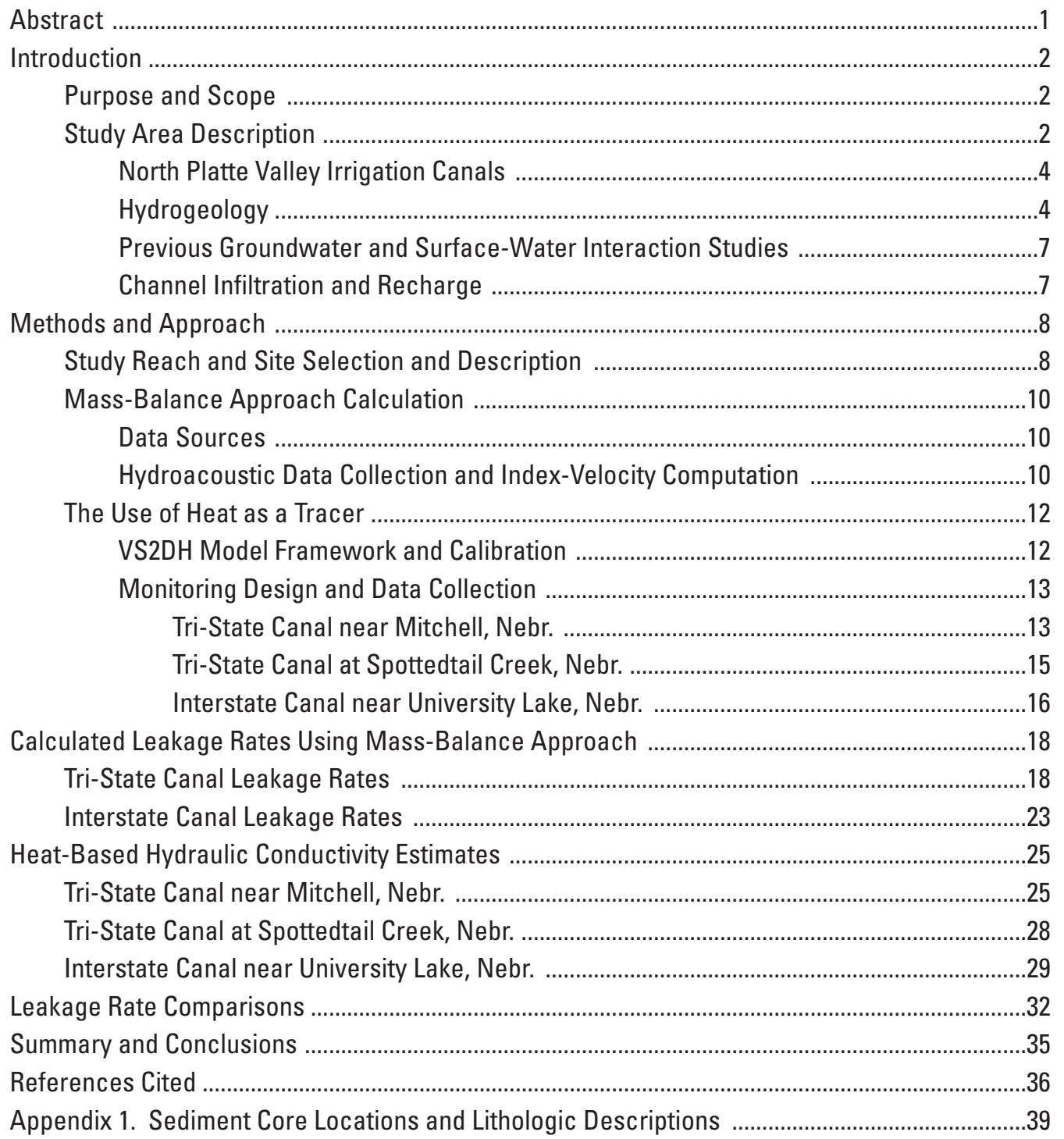

\section{Figures}

1. Location of study area within the North Platte Natural Resources District .....................3

2. Map showing selected study reaches and location of streamflow-gaging stations and temperature monitoring sites, Interstate and Tri-State Canals, western

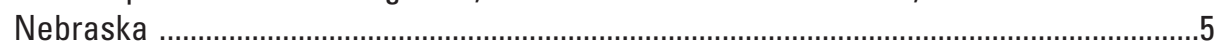

3. Generalized geologic sections $A-A^{\prime}$ and $B-B^{\prime}$ showing principal geologic units ..........6

4. Generalized one-dimensional VS2DH model of water and heat transport through canal-bed sediment

5. Example subsurface temperature data from paired deep and shallow thermocouples: pre-processed, unfiltered data display an artificial diurnal variation, and post-processed, filtered data have had artificial diurnal variation removed 
6. Generalized diagram (A) and map (B) of monitoring installation design used at site TCTEMP1, Tri-State Canal near Mitchell, Nebr.

7. Generalized diagram $(\mathrm{A})$ and $\operatorname{map}(\mathrm{B})$ of monitoring installation design used at site TCTEMP2, Tri-State Canal at Spottedtail Creek, Nebr.

8. Generalized diagram $(A)$ and map $(B)$ of monitoring installation design used at site ICTEMP, Interstate Canal near University Lake, Nebr.

9. Daily mean upstream discharge, downstream discharge, and bed leakage rate, Tri-State Canal, late June to September, 2007

10. Daily mean upstream discharge, downstream discharge, and bed leakage rate, Tri-State Canal, late June to early August, 2008

11. Daily mean upstream discharge, downstream discharge, and bed leakage rate, Tri-State Canal, early July to late August, 2009

12. Monthly mean streamflow of North Platte River at the Nebraska-Wyoming state line (streamflow-gaging station 06674500 ) and total monthly precipitation measured at Scottsbluff Airport, January 2007 through December 2009

13. Daily mean upstream discharge, downstream discharge, and bed leakage rate, Interstate Canal, May to mid-August, 2007

14. Daily mean upstream discharge, downstream discharge, and bed leakage rate, Interstate Canal, late April to early August, 2008

15. Daily mean upstream discharge, downstream discharge, and bed leakage rate, Interstate Canal, early July to late August, 2009

16. Thermograph of sediment beneath Tri-State Canal from vertical sensor array 4 during initiation of seasonal flow, June 2007

17. Groundwater level recorded near Tri-State Canal near Mitchell, Nebr., June 2007 ......26

18. Water temperature and stage in Tri-State Canal near Mitchell, Nebr., May through September, 2007

19. Measured and simulated thermographs for saturated sediment at (A) 0.15 meter and (B) 0.76 meter beneath Tri-State Canal near Mitchell, Nebr., 2007

20. Measured and simulated thermographs for saturated sediment at (A) 0.15 meter and (B) 0.76 meter beneath Tri-State Canal near Mitchell, Nebr., 2009

21. Measured and simulated thermographs for saturated sediment (including a hypothetical top layer of silt) at (A) 0.15 meter and (B) 0.76 meter beneath Tri-State Canal near Mitchell, Nebr., 2008

22. Water temperature and stage in Tri-State Canal at Spottedtail Creek, Nebr., May to October, 2009

23. Pressure head and temperature recorded 0.91 meter below Tri-State Canal at Spottedtail Creek, Nebr., May to October, 2009

24. Canal stage and hydraulic gradient measured beneath Tri-State Canal at Spottedtail Creek (A), discharge reported at Spottedtail Creek streamflow-gaging station, and precipitation recorded at Scottsbluff Airport (B), March to October 2009

25. Example measured and simulated thermographs for saturated sediment at (A) $0.15 \mathrm{~m}$ and (B) 0.76 meter beneath Tri-State Canal at Spottedtail Creek, Nebr., 2009

26. Groundwater level and temperature recorded at monitoring well 420233103441301, Interstate Canal near University Lake, Nebr., April to October, 2008

27. Canal water temperature and stage of Interstate Canal, April to mid-September, 2008

28. Measured thermographs of sediment beneath Interstate Canal near University Lake, Nebr., from selected depths in vertical sensor arrays, April to October, 2008 .....34 
29. Measured and simulated thermographs for saturated sediment at (A) 0.15 meter and (B) 0.76 meter beneath Interstate Canal near University Lake, Nebr., July 2008

\section{Tables}

1. Field names and locations of streamflow-gaging stations and temperature monitoring sites ......

2. Summary statistics for Acoustic Doppler Current Profiler (ADCP) measurements including percent difference between ADCP and computed discharge from Tri-State Canal and Interstate Canal streamflow-gaging stations, 2007-09 .

3. Summary of hydraulic and thermal properties used in final VS2DH models for each temperature monitoring site 


\section{Conversion Factors}

\section{SI to Inch/Pound}

\begin{tabular}{lcl}
\hline \multicolumn{1}{c}{ Multiply } & By & \multicolumn{1}{c}{ To obtain } \\
\hline centimeter $(\mathrm{cm})$ & Length & inch (in.) \\
meter $(\mathrm{m})$ & 0.3937 & foot $(\mathrm{ft})$ \\
kilometer $(\mathrm{km})$ & 3.281 & mile $(\mathrm{mi})$ \\
\hline & 0.6214 & \\
\hline hectare $(\mathrm{ha})$ & Area & acre \\
hectare $($ ha) & 2.471 & square mile $\left(\mathrm{mi}^{2}\right)$ \\
square kilometer $\left(\mathrm{km}^{2}\right)$ & 0.003861 & square mile $\left(\mathrm{mi}{ }^{2}\right)$ \\
square meter $\left(\mathrm{m}^{2}\right)$ & 0.3861 & square foot $\left(\mathrm{ft}{ }^{2}\right)$ \\
\hline & 10.76 & acre-foot $(\mathrm{acre}-\mathrm{ft})$ \\
\hline cubic meter $\left(\mathrm{m}^{3}\right)$ & Volume & acre-foot $(\mathrm{acre}-\mathrm{ft})$ \\
cubic hectometer $\left(\mathrm{hm}{ }^{3}\right)$ & 0.0008107 & \\
\hline & 810.7 & foot per second $(\mathrm{ft} / \mathrm{s})$ \\
\hline meter per second $(\mathrm{m} / \mathrm{s})$ & Flow rate & foot per day $(\mathrm{ft} / \mathrm{d})$ \\
meter per day $(\mathrm{m} / \mathrm{d})$ & 3.281 & cubic foot per second $\left(\mathrm{ft}{ }^{3} / \mathrm{s}\right)$ \\
cubic meter per second $\left(\mathrm{m}^{3} / \mathrm{s}\right)$ & 3.281 & inch per year $(\mathrm{in} / \mathrm{yr})$ \\
centimeters per year $(\mathrm{cm} / \mathrm{yr})$ & 35.31 & feet per foot $(\mathrm{ft} / \mathrm{ft})$ \\
\hline meters per meter $\left(\mathrm{m} / \mathrm{m}^{2}\right)$ & 0.3937 & \\
\hline
\end{tabular}

Temperature in degrees Celsius $\left({ }^{\circ} \mathrm{C}\right)$ may be converted to degrees Fahrenheit $\left({ }^{\circ} \mathrm{F}\right)$ as follows:

$$
{ }^{\circ} \mathrm{F}=\left(1.8 \mathrm{x}^{\circ} \mathrm{C}\right)+32
$$

Temperature in degrees Fahrenheit $\left({ }^{\circ} \mathrm{F}\right)$ may be converted to degrees Celsius $\left({ }^{\circ} \mathrm{C}\right)$ as follows:

$$
{ }^{\circ} \mathrm{C}=\left({ }^{\circ} \mathrm{F}-32\right) / 1.8
$$

Vertical coordinate information is referenced to the North American Vertical Datum of 1988 (NAVD 88).

Horizontal coordinate information is referenced to the North American Datum of 1983 (NAD 83). Altitude, as used in this report, refers to distance above the vertical datum.

Concentrations of chemical constituents in water are given either in milligrams per liter (mg/L) or micrograms per liter $(\mu \mathrm{g} / \mathrm{L})$. 


\title{
Quantifying Canal Leakage Rates Using a Mass-Balance Approach and Heat-Based Hydraulic Conductivity Estimates in Selected Irrigation Canals, Western Nebraska, 2007 through 2009
}

\author{
By Christopher M. Hobza and Michael J. Andersen
}

\begin{abstract}
The water supply in areas of the North Platte River Basin in the Nebraska Panhandle has been designated as fully appropriated or overappropriated by the Nebraska Department of Natural Resources (NDNR). Enacted legislation (Legislative Bill 962) requires the North Platte Natural Resources District (NPNRD) and the NDNR to develop an Integrated Management Plan (IMP) to balance groundwater and surface-water supply and demand in the NPNRD. A clear understanding of the groundwater and surface-water systems is critical for the development of a successful IMP. The primary source of groundwater recharge in parts of the NPNRD is from irrigation canal leakage. Because canal leakage constitutes a large part of the hydrologic budget, spatially distributing canal leakage to the groundwater system is important to any management strategy. Surface geophysical data collected along selected reaches of irrigation canals has allowed for the spatial distribution of leakage on a relative basis; however, the actual magnitude of leakage remains poorly defined. To address this need, the U.S. Geological Survey, in cooperation with the NPNRD, established streamflow-gaging stations at upstream and downstream ends from two selected canal reaches to allow a mass-balance approach to be used to calculate daily leakage rates. Water-level and sediment temperature data were collected and simulated at three temperature monitoring sites to allow the use of heat as a tracer to estimate the hydraulic conductivity of canal-bed sediment. Canal-leakage rates were estimated by applying Darcy's Law to modeled vertical hydraulic conductivity and either the estimated or measured hydraulic gradient. This approach will improve the understanding of the spatial and temporal variability of canal leakage in varying geologic settings identified in capacitively coupled resistivity surveys.

The high-leakage potential study reach of the Tri-State Canal had two streamflow-gaging stations and two temperature monitoring sites along its length. Calculated leakage rates from the mass-balance approach varied from year to year and were generally dependent on local climatic conditions, and
\end{abstract}

the timing and magnitude of the initial seasonal diversion into the Tri-State Canal. Leakage rates ranged from 0.98 meter per day $(\mathrm{m} / \mathrm{d})$ on June 22,2007 , to about to $0 \mathrm{~m} / \mathrm{d}$ during July 2009. Drier conditions generally resulted in higher leakage rates because of reduced flow from Spottedtail Creek, lower groundwater levels near Spottedtail Creek, and no unmeasured flow entering the reach. Of the three years studied (2007-09), 2007 was the driest, and therefore had the highest canal leakage rates.

The moderately low-leakage potential study reach of Interstate Canal had two streamflow-gaging stations and one temperature monitoring site along its length. Excluding the leakage calculations from early May 2007, leakage rates ranged from 0.08 to $0.7 \mathrm{~m} / \mathrm{d}$. Less variability in leakage from year to year indicates that climatic conditions may have less of an effect for Interstate Canal compared to Tri-State Canal. This may be because Interstate Canal was cut into the northern edge of the North Platte alluvial valley and consequently the canal bed is well above the local groundwater table resulting in a constant $(1$ meter per meter $[\mathrm{m} / \mathrm{m}])$ hydraulic gradient. Interstate Canal also does not receive any captured flow that can vary substantially year to year.

Two temperature monitoring sites were installed within the high-leakage potential reach of Tri-State Canal. Site TCTEMP1 was established in 2007 where the water table was well below the canal-bed surface. The vertical hydraulic conductivity of the poorly sorted sand and gravel beneath site TCTEMP1 was estimated using a calibrated one-dimensional VS2DH model. Using a trial-and-error approach, the best-fit vertical hydraulic conductivity for the site TCTEMP1 model domain was $1.1 \mathrm{~m} / \mathrm{d}$. Site TCTEMP2 was established at the mouth of Spottedtail Creek where a shallow water table may restrict canal leakage. The mean vertical hydraulic conductivity estimated from the best-fit VS2DH model was $1.5 \mathrm{~m} / \mathrm{d}$; however, measured hydraulic gradients ranged from -0.14 to $-0.07 \mathrm{~m} / \mathrm{m}$, resulting in canal leakage rates that ranged from 0.1 to $0.2 \mathrm{~m} / \mathrm{d}$. Because hydraulic gradient only was collected at one point, it was not possible to spatially extrapolate this estimate to other parts of the high-leakage potential reach. 
Site ICTEMP is a temperature monitoring site that was established in 2008 to estimate the hydraulic conductivity of near-surface sediments, and to understand canal leakage and recharge mechanisms in a fractured Brule setting. Based on the thicknesses and modeled vertical hydraulic conductivities, an average vertical hydraulic conductivity of $0.74 \mathrm{~m} / \mathrm{d}$ was computed. The vertical hydraulic conductivity of the least permeable layer had the greatest effect on the mean vertical hydraulic conductivity, and therefore, canal leakage. The hydraulic gradient is assumed to be $1 \mathrm{~m} / \mathrm{m}$ because the bed of the canal is well above the water table along the study reach; therefore, the canal-leakage rate at site ICTEMP is estimated to be $0.74 \mathrm{~m} / \mathrm{d}$.

\section{Introduction}

The water supply in areas of the North Platte River Basin in the Nebraska Panhandle has been designated as fully appropriated or overappropriated by the Nebraska Department of Natural Resources (NDNR). Enacted legislation (Legislative Bill 962) requires the North Platte Natural Resources District (NPNRD) and the NDNR to develop an Integrated Management Plan (IMP) to balance groundwater and surface-water supply and demand in the NPNRD (fig. 1) (Ostdiek, 2009). A clear understanding of the groundwater and surface-water systems is critical for the development of a successful IMP.

As part of the IMP, improved decision-making tools are needed to analyze the effects of different groundwater management strategies on base flow of the North Platte River. To fulfill that need, a groundwater model is being constructed (NPNRD groundwater model area, fig. 1) that will evaluate the effects of specific management options such as intentional groundwater recharge and changes in pumpage (S.M. Peterson, U.S. Geological Survey, oral commun., 2008). The primary source of groundwater recharge in parts of the NPNRD is from irrigation canal leakage (Verstraeten and others, 2001). Canals in the area leak approximately 40 to 50 percent of the diverted surface-water into underlying aquifers (Luckey and Cannia, 2006).

Because canal leakage constitutes a large part of the hydrologic budget, spatially distributing canal leakage to the groundwater system is important to the accuracy of any groundwater model. Surface geophysical data collected along selected reaches of irrigation canals has allowed for the spatial distribution of leakage on a relative basis (Ball and others, 2006; Burton and others, 2009); however, the actual magnitude of leakage remains poorly defined. Before the release of this report, the relative distribution of canal leakage was estimated on the basis of interpreted lithology from test holes and capacitively coupled resistivity (CCR) surveys (Ball and others, 2006; Burton and others, 2009). Large ranges in vertical hydraulic conductivity, often of several orders of magnitude, exist among the various sediment textures present locally (Domenico and Schwartz,
1998), which can affect the degree of leakage. Moreover, CCR surveys may not detect thin near-surface layers of fine sediment that can clog the bed (Sophocleous and others, 1995) and affect the rate of leakage. To address this need, the U.S. Geological Survey, in cooperation with the NPNRD, established streamflow-gaging stations at upstream and downstream ends from two selected canal reaches to allow a mass-balance approach to be used to calculate daily leakage rates. Waterlevel and sediment temperature data were collected and simulated at three temperature monitoring sites to estimate the hydraulic conductivity of canal-bed sediment. Canal-leakage rates were estimated by applying Darcy's Law based on modeled vertical hydraulic conductivity and either the estimated or measured hydraulic gradient. This approach will improve the understanding of the spatial and temporal variability of canal leakage in varying geologic settings identified in CCR surveys.

\section{Purpose and Scope}

This report presents canal-leakage rates for selected reaches of Tri-State and Interstate Canals in western Nebraska. Based on CCR profiles, Ball and others (2006) identified a reach where the Tri-State Canal cuts through a section of Quaternary alluvial sand and gravel as having a predominantly high-leakage potential reach. They interpreted a moderately low-leakage potential for a reach where Interstate Canal cuts through several outcrops of weathered and fractured Brule Formation of the White River Group of Tertiary age (referred to hereinafter as the Brule Formation). Differences in streamflow measured at upstream and downstream locations allow a mass-balance approach to quantify canal-leakage rates from 2007 through 2009. The report includes plots of average daily discharge and daily canal-leakage rates. At each study reach, continuous water temperature and waterlevel data were used as inputs to the groundwater-flow model VS2DH (Healy and Ronan, 1996) to estimate the mean vertical hydraulic conductivity of the canal-bed sediment. Example water temperature and water-level time-series plots are included in this report. Lithologic descriptions of sediment cores, including core depth, texture, and color also are presented.

\section{Study Area Description}

The methods and approaches described in this report have been applied to two selected reaches of two irrigation canals, but potentially may be applied to other reaches of irrigation canals within the study area. For this reason, the study area for this report is considered to be the entire NPNRD groundwater model area (fig. 1), which is located within the NPNRD and encompasses approximately 393,000 hectares (ha) along the North Platte River west of Bridgeport, Nebr., to the Nebraska-Wyoming border. The North Platte Valley west of Bridgeport is characterized by bottomland, terraces with 

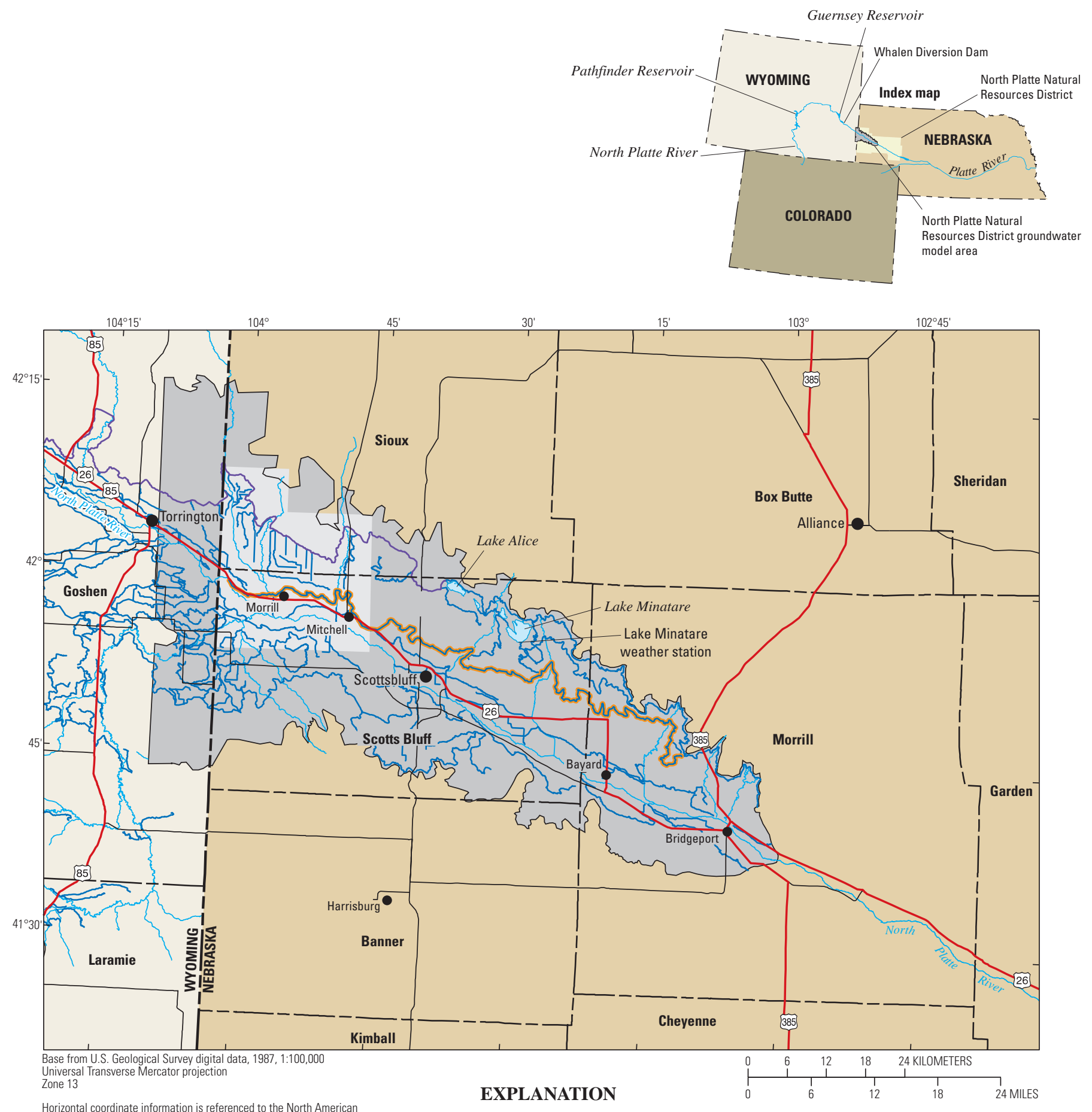

Horizontal coordinate information is referenced to the North American

EXPLANATION

Boundary of North Platte Natural Resources District groundwater model area (study area)

Dutch Flats area

Interstate Canal

\section{Tri-State Canal}

Canal

Figure 1. Location of study area within the North Platte Natural Resources District. 
upland areas, escarpments of tablelands north of the North Platte River, and footslopes south of the North Platte River (Verstraeten and others, 2001). The study area has a semi-arid climate with a large temperature range typical of mid-latitude continental locations. The mean annual precipitation at the Scottsbluff Airport was 41.5 centimeters (cm) for 1970-2000 (National Oceanic and Atmospheric Administration, 2007). The long-term estimated mean annual evaporative demand near Mitchell, Nebr., was 40.6 centimeters per year (cm/year) (Luckey and Cannia, 2006).

Based on 2005 information, land use in the study area is about 58 percent range and pasture land, 36 percent cropland (dryland and irrigated land), 3 percent wetland (open water and vegetated wetlands), 1.5 percent urban, 1.2 percent forest and woodlands, and 1 percent barren (Center for Advanced Land Management Information Technologies, 2007). The primary crops raised in the area are corn, beans, sugar beets, and alfalfa (Verstraeten and others, 2001). Crop water demands not satisfied by precipitation are supplemented either with surface water supplied by irrigation canals, or groundwater applied from center-pivot or gravity-irrigation systems (Verstraeten and others, 2001).

\section{North Platte Valley Irrigation Canals}

Shortly after the Federal Reclamation Act was signed in 1902 (Bureau of Reclamation, 2009b), the Bureau of Reclamation North Platte Project was created to irrigate 91,500 ha of the North Platte Valley in eastern Wyoming and western Nebraska. Since construction of Pathfinder Dam and Interstate Canal in 1905, Guernsey Reservoir and Whalen Diversion Dam (fig. 1) have been constructed along with 542 kilometers $(\mathrm{km})$ of canals. The North Platte Project provides irrigation water to hay and cropland (Bureau of Reclamation, 2009b) through Interstate and Tri-State Canals, which are the largest of 19 canals in the study area, and supply water to 47,400 and 20,300 ha, respectively (Ball and others, 2006).

Interstate Canal, operated by Pathfinder Irrigation District (Mitchell, Nebr.), diverts water from the Whalen Diversion Dam, $55 \mathrm{~km}$ west of the Nebraska-Wyoming state line. Pathfinder Irrigation District owns a water right for 44.5 cubic meters per second $\left(\mathrm{m}^{3} / \mathrm{s}\right)(1,572$ cubic feet per second $\left[\mathrm{ft}^{3} / \mathrm{s}\right]$ ) dated 1904, and also receives storage water from the Bureau of Reclamation North Platte Project (Nebraska Department of Natural Resources, 2009). Interstate Canal ends at the High Line Canal (not shown on map) and Lake Alice north of Scottsbluff, Nebr. Interstate Canal is located at the northern edge of the ancestral North Platte Valley and is bordered by rangeland and groundwater-irrigated cropland to the north. Interstate Canal is bordered to the south by groundwater- and surface-water-irrigated cropland. Interstate Canal cuts through multiple outcrops of the Brule Formation from the Nebraska-Wyoming state line east toward Scottsbluff (Ball and others, 2006) (fig. 1).
Tri-State Canal, operated by Farmers Irrigation District (Scottsbluff, Nebr.), diverts water from the North Platte River about $10 \mathrm{~km}$ northwest of Morrill, Nebr., and ends at North Port Irrigation District (Bridgeport, Nebr.) in the eastern part of the study area near Bayard, Nebr. Farmers Irrigation District owns water rights for $40.7 \mathrm{~m}^{3} / \mathrm{s}\left(1,438 \mathrm{ft}^{3} / \mathrm{s}\right)$ dated from 1887 and 1902. Farmers Irrigation District also has water rights to divert from several tributaries of the North Platte River and purchases surplus water from the North Platte Project (Nebraska Department of Natural Resources, 2009). Several streams flow into Tri-State Canal in the study area, including Sheep Creek, Akers Draw, Dry Spottedtail Creek, and Spottedtail Creek (fig. 2).

The irrigation season is divided into two diversion periods: the hay run and the primary irrigation season. When water supplies are available, diversions from the North Platte River to the Interstate and Tri-State Canals commonly begin in April for early irrigation of hay fields and meadows (referred to as the hay run). Drought conditions can delay diversions until mid- to late May or June. Diversions for the hay run typically are much less than those during the primary irrigation season, which occurs from June through September. Even when water-supply conditions prevent the early irrigation of hay fields and meadows, Interstate Canal still diverts water to fill downstream lakes during April of each year to satisfy interstate decree requirements. Diversions cease each year around September 30, which coincides with the end of the growing season for row crops. Thereafter, Tri-State Canal continues to receive water from Akers Draw, Spottedtail Creek, and Tub Springs Drain (fig. 2) during a period that is locally referred to as natural flow. The quantity and duration of captured streamflow during natural flow varies annually and depends on climatic conditions.

\section{Hydrogeology}

Previous investigations have described the geology and occurrence of groundwater within the study area (Darton, 1903a, 1903b; Wenzel and others, 1946; Babcock and Visher, 1951; Verstraeten and others, 1995; Verstraeten and others, 2001; Ball and others, 2006). Generalized geologic sections within the Dutch Flats area (fig. 1) from Verstraeten and others (2001) are presented in figure 3. A more thorough discussion of the groundwater and surface-water interaction of the Dutch Flats area is presented by Verstraeten and others (2001).

The shallowest groundwater system in the study area is the unconfined alluvial aquifer. The alluvial aquifer is composed of Quaternary sand and gravel that mantle the Brule Formation or Cretaceous sediment (not shown in crosssection). A subsurface ridge or "high" in the Brule Formation (referred to hereafter as Brule high) divides the alluvial aquifer into northern and southern parts between Interstate and TriState Canal (fig. 3). The Brule high separates the paleochannels of the ancestral North Platte Valley north of the bedrock high (the upland valley) from the present North Platte River 


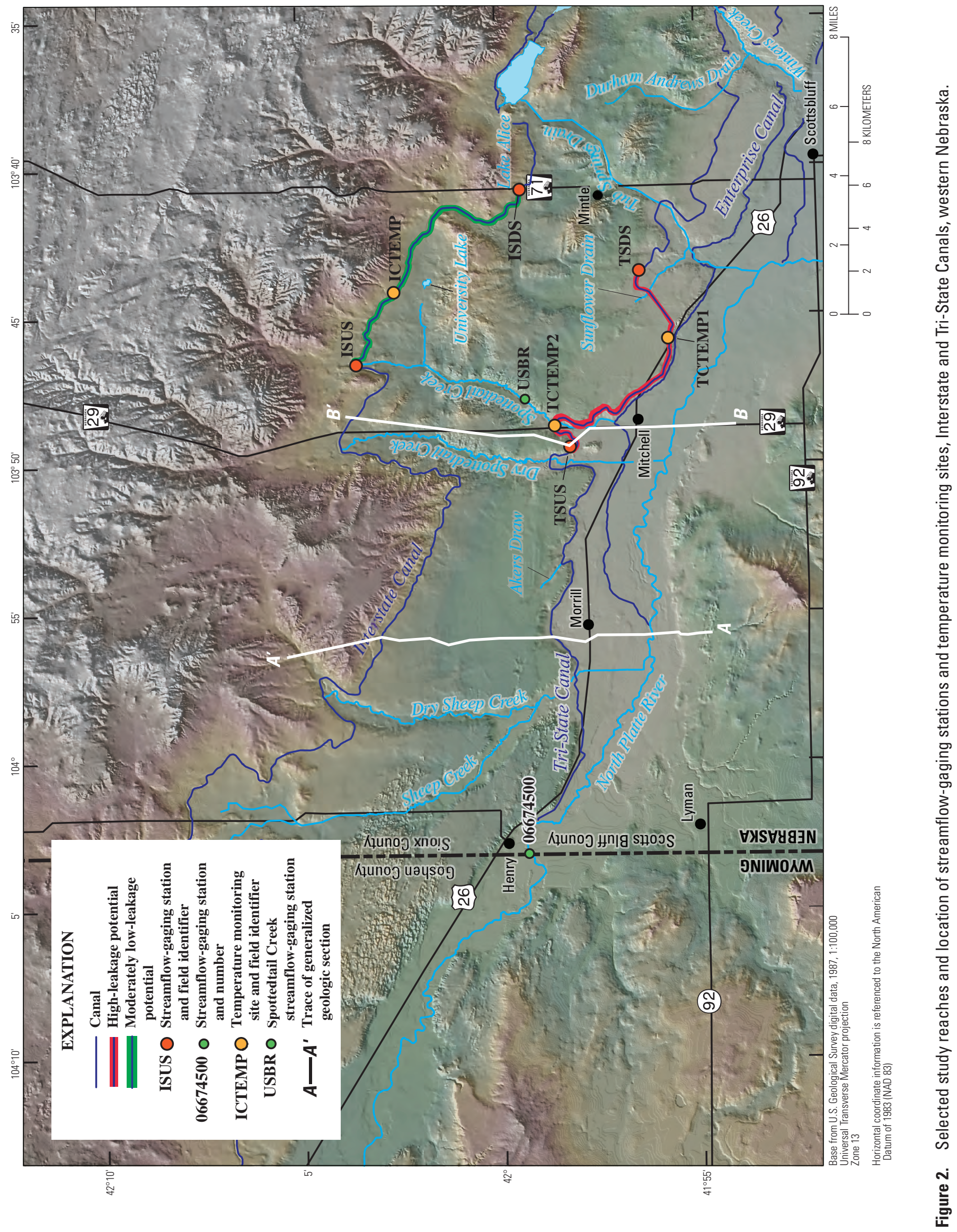




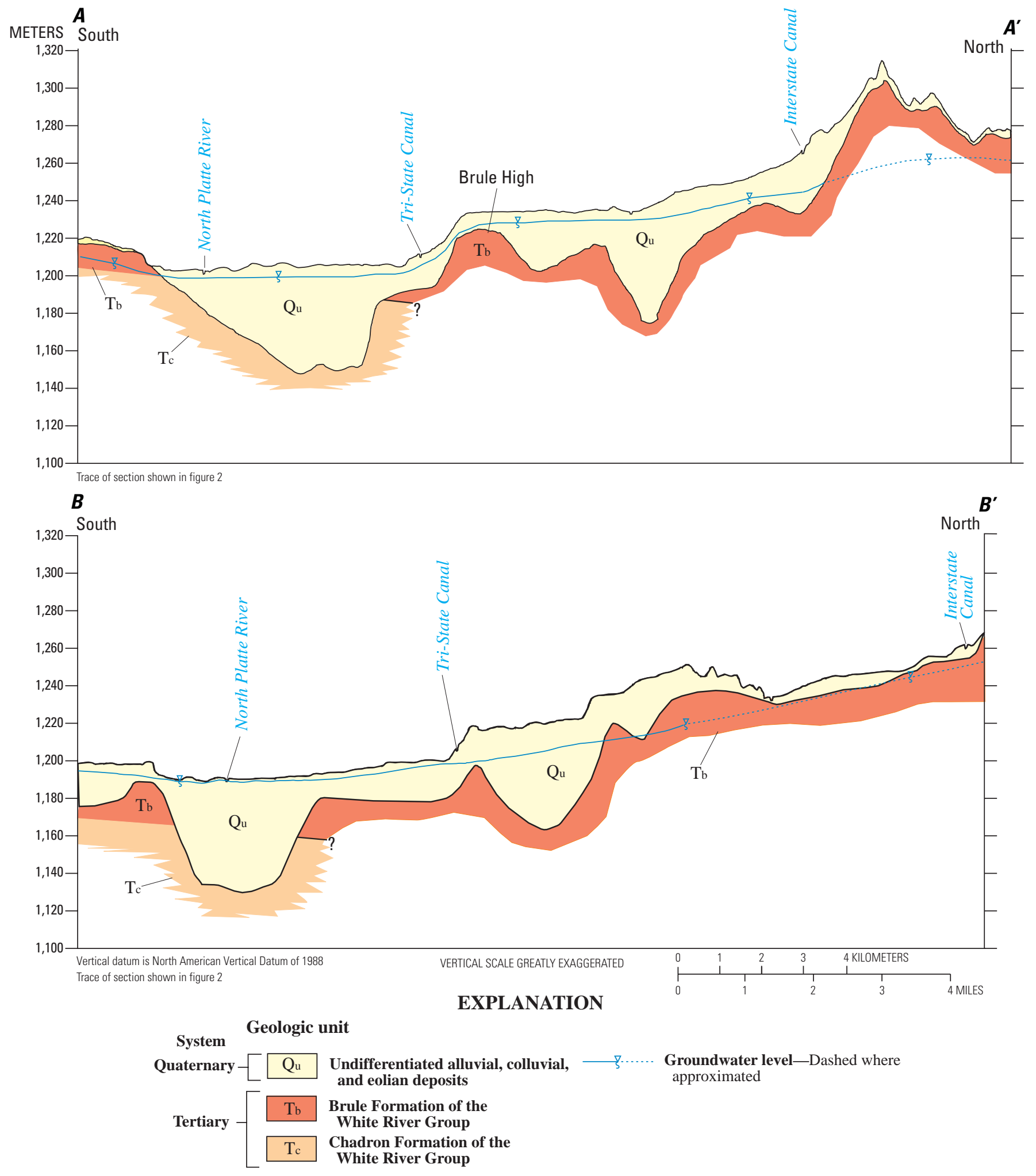

Figure 3. Generalized geologic sections $A-A^{\prime}$ and $B-B^{\prime}$ showing principal geologic units. (Modified from Verstraeten and others, 2001.) 
(the bottomland). Alluvial aquifer thickness is extremely variable with a maximum thickness of more than 80 meters (m) (Cooperative Hydrology Study, 2007). Depth to water in the northern alluvial aquifer ranges from 1.5 to $24 \mathrm{~m}$ and typically is less than $6 \mathrm{~m}$ below land surface in the southern alluvial aquifer (Ball and others, 2006).

The Brule Formation is used as a water source only when fractured or containing alluvial deposits (Luckey and Cannia, 2006). The unfractured horizontal hydraulic conductivity of this unit is low $\left(1 \times 10^{-7}\right.$ to $1 \times 10^{-6}$ meters/second $[\mathrm{m} / \mathrm{s}]$ ) (Barrash and Morin, 1987); however, where adequate water supplies exist the Brule Formation is considered part of the High Plains aquifer (not shown on map) (Gutentag and others, 1984). Sustainable yields to wells are dependent upon the number, size, and continuity of fractures, and the availability of recharge from a surface-water source or connection to alluvial aquifers (J.C. Cannia, U.S. Geological Survey, oral commun., 2007).

Fracturing of the Brule Formation is largely limited to the upper parts (Harvey and Sibray, 2001). Approximately $100 \mathrm{~km}$ south of the study area, near Sidney, Nebr. (not shown on map), Sibray and Zhang (1994) reported a horizontal conductivity of $8 \times 10^{-2} \mathrm{~m} / \mathrm{s}$ and a vertical hydraulic conductivity of $1 \times 10^{-5} \mathrm{~m} / \mathrm{s}$ for the upper Brule Formation based on analytical modeling of aquifer test data. Values reported for the lower Brule Formation were much less and ranged from $1 \times 10^{-6}$ to $1 \times 10^{-8} \mathrm{~m} / \mathrm{s}$.

Groundwater movement in the study area generally is toward the North Platte River or its tributaries (Verstraeten and others, 2001). A Brule high in the western part of the study area causes groundwater flow to deviate from the predominant north-south direction. In the part of the alluvial aquifer between the Brule high and the North Platte River, groundwater moves from areas recharged by groundwater from the northern alluvial aquifer toward the North Platte River (Ball and others, 2006).

\section{Previous Groundwater and Surface-Water Interaction Studies}

Understanding the interaction of groundwater and surface-water systems is essential to sound water-resource management and policy (Winters and others, 1998). Groundwater/surface-water interaction and the effects of canals on the local hydrology have been a focus of study in the North Platte Valley since Darton (1903b) described the geology and water resources of the area. The interaction of groundwater and surface water has been explored by examining recharge, modeling results (Luckey and Cannia, 2006), and chemical transport.

Recharge to the groundwater system in the study area from precipitation is much less than leakage from irrigation canals, laterals, and infiltration of applied irrigation water (Babcock and Visher, 1951; Harvey and Sibray, 2001; Verstraeten and others, 2001; Luckey and Cannia, 2006). Monitoring wells located near irrigation canals record groundwater-level rises shortly after surface water is diverted into irrigation canals, and typically record water-level declines after the diversions cease. During the irrigation season, leakage through canal beds affects the movement of groundwater by increasing the hydraulic head in the aquifer near the canals. As the groundwater hydraulic head near the canal increases, the overall hydraulic gradient of the groundwater flow system also increases. Subsequently, groundwater moves from recharge areas near the canals to discharge areas, which increases base flow of streams in the North Platte Valley. Wenzel and others (1946) reported that "prior to 1911 the aggregate discharge of all the tributaries to the North Platte River from the State line (Nebraska-Wyoming) to Bridgeport was less than 25,000 acre-feet a year; since 1927 it has in no year been less than 300,000 acre-feet."

Irrigation system losses from canal and lateral leakage have been estimated for many of the canals in western Nebraska by Bishop-Brogden Associates (2002). System losses for Pathfinder and Farmers Irrigation Districts were estimated at 51 and 41 percent, respectively, of their diversion before reaching cropland. Of these calculated system losses, it was estimated that 71 percent is leakage from canals, and 29 percent is leakage from laterals (Dennis Strauch, Pathfinder Irrigation District, oral commun., 2010).

The strong connection between groundwater and surface water in the study area also has been reflected in water-quality and chemistry data. Locally, irrigation canals have caused seasonal changes in groundwater quality. Nitrate concentrations of shallow groundwater typically decrease in the irrigation season as a result of leakage and subsequent mixing with and dilution of shallow groundwater (Verstraeten and others, 2002). These localized effects are greatest for areas of, or adjacent to, Interstate Canal near the northernmost part of the valley and diminish southward toward Tri-State Canal. Groundwater age dating has indicated that groundwater in the alluvium recharged less than 30 years ago and averaged 9 years ago in the Dutch Flats area of the North Platte Valley (Verstraeten and others, 2002).

\section{Channel Infiltration and Recharge}

Evaluating and quantifying recharge from irrigation canals and ephemeral stream channels has been the focus of many groundwater recharge and availability studies. The primary sources of groundwater recharge in many arid and semiarid regions in many cases are seepage from ephemeral streambeds (Stonestrom and others, 2007) and leakage from canals (Verstraeten and others, 2001). Although ephemeral streams and seasonal canals have considerably different flow characteristics, they share many of the same unsaturated-zone flow processes, such as hysteretic effects of wetting and drying of sediments. Stonestrom and others (2007) reported numerous case studies examining groundwater recharge from ephemeral streambeds in arid and semiarid areas in the southwestern United States. Groundwater recharge is focused along stream and canal reaches because large amounts of water are available 
for seepage and strong hydraulic gradients exist to drive seepage (Dages and others, 2008).

Quantifying the amount of recharge from surface-water sources is more difficult for ephemeral streams than for irrigation canals because geologic, hydrologic, and meteorological conditions often are highly variable, (Stephens and others, 1988), and therefore, manifest greater flow-rate variability in natural systems rather than managed conduits. The amount of recharge received by underlying aquifers from channel infiltration is affected by many factors, including bed sediment texture, depth to groundwater, channel geometry, available unsaturated-zone storage volume, flow duration and depth, volumetric soil-water content, and the presence of clogging layers (Robinson and Rohwer, 1957 1959; Stephens, 1996). Streamflow measurement can be difficult under these conditions because runoff events are often flashy and erosive, which creates operational problems for maintaining instrumentation (Stephens and others, 1988).

In order for leakage through an irrigation canal or recharge from an ephemeral stream to occur, water must infiltrate the bed sediment and reach the water table. Onedimensional, steady-state, vertical flow of water through unsaturated homogenous porous media can be described with a form of Darcy's Law (Hoffman and others, 2007):

$$
\mathbf{q}=K(\theta)\left(\frac{\partial \psi}{\partial z}+1\right)
$$

where,

$q$ is the flux [length units/time units],

$\theta$ is the volumetric soil-water content [volume units/ volume units],

$\mathrm{K}(\theta)$ is the hydraulic conductivity [length units/time units] as a function of the volumetric soil-water content,

$\psi$ is the pressure head of the water [length units], and

$z$ is the vertical dimension [length units].

Thus, determination of the rate of flow in the unsaturated zone requires knowledge of the hydraulic conductivity (which is dependent on the degree of saturation) and the pressurehead gradient (Hoffman and others, 2007).

Recharge characteristics were studied with several techniques at various spatial and temporal scales along Rillito Creek in Arizona (not shown on map) (Hoffman and others, 2007). A two-dimensional temperature and water-content array was used to examine the redistribution of water in the unsaturated zone. High infiltration rates were measured at the onset of infiltration because of high hydraulic conductivity in the underlying sandy sediment and low volumetric water content creating large capillary pressure-head gradients. Multidimensional flow was present with lateral velocities roughly equivalent to vertical velocities. Shortly after the onset of infiltration the near-surface sediment became saturated causing the strong capillary gradients to disappear. As capillary gradients disappeared, gravity became the dominant force in water movement, and flow primarily became vertical
(Hoffman and others, 2007). The investigators reported that when saturated conditions persist, Darcy's Law (Freeze and Cherry, 1979) can be used to calculate the flow rate, provided the hydraulic conductivity and hydraulic gradient are known. If a unit hydraulic gradient is assumed then the potential recharge rate becomes equivalent to the saturated hydraulic conductivity of the underlying sediment.

Other investigations have studied recharge patterns from a drainage ditch and examined its effect on local groundwater levels using several transects of piezometers and tensiometers (Dages and others, 2008). During the initiation of flow in the ditch, the rates of leakage were high and large horizontal and vertical moisture gradients were measured. Sediment beneath the ditch quickly reached saturation extending to the water table, which created a large groundwater mound that extended beyond the banks of the ditch. A nearly instantaneous response of the water table was recorded at some distance from the ditch because the downward and laterally flowing water resulted in a synchronous pressure wave. This pressure wave propagated normally from the ditch, causing nearly instantaneous groundwater-level rises.

\section{Methods and Approach}

This section of the report describes the methods and approaches used to quantify canal leakage rates from two selected study reaches using a mass-balance approach and heat-based hydraulic conductivity estimates. Included in this section is the rationale for reach and site selection as well as brief descriptions of each study reach. The mass-balance approach used for this report is described including the additional data sources needed and the methods of hydroacoustic data collection and discharge computation. A brief introduction to the technique of using heat as a tracer and the VS2DH model framework and calibration procedures also are provided. The instrumentation used for each temperature monitoring site is described, as well as the monitoring design and the data-collection procedures.

\section{Study Reach and Site Selection and Description}

Two study reaches were chosen to represent contrasting areas with high and moderately low-leakage potential. Each study reach was of sufficient length that the potential leakage loss was greater than the expected uncertainty of the leakage calculation, yet minimizing the amount of unmeasured return flows, diversions, or additional variables that would increase the extraneous uncertainty of the calculated leakage. Interpretations of previously collected CCR profiles (Ball and others, 2006; Burton and others, 2009) indicate a predominantly high-leakage potential for the reach where Tri-State Canal cuts through a section of alluvial sand and gravel, and a moderately low-leakage potential where Interstate Canal cuts through outcrops of fractured and weathered bedrock of 
the Brule Formation. Capacitively coupled resistivity profiles (Ball and others, 2006) indicated that within the moderately low-leakage potential reach thin sand and silt deposits cover the Brule Formation in some areas. Harvey and Sibray (2001) collected water-level and water-quality data to determine the effect of canal leakage on the local hydrology of the University Lake area (fig. 2). In their study area, the upper part of the Brule Formation is weathered with localized fracturing (S.S. Sibray, University of Nebraska, oral commun., 2010) and is the primary source of recharge in this area providing water to the alluvial aquifer and the upper parts of the Brule Formation (Verstraeten and others, 2001).

These selected reaches were bounded by streamflowgaging stations at upstream and downstream locations to allow a mass-balance approach to be used to calculate canal leakage rates. To accurately quantify canal leakage within the two selected study reaches, the determination of the exact streamflow-gaging station location required careful consideration of several variables. The selected reaches had to be of sufficient length that the leakage loss was greater than the dischargecomputation error of both streamgages; the total magnitude of unmeasured return flows, diversions, or other gains or losses had to be minimized; and the characteristics of the streamgaging cross-section had to be desirable, as defined by Rantz (1982). Within each study reach, at least one temperature monitoring site was selected for estimating the vertical hydraulic conductivity of various sediment textures. Within the highleakage potential reach, one site was established well above the water table, and one site was established where a shallow water table might restrict leakage by reducing the hydraulic gradient. Within the moderately low-leakage potential reach, one site was established to examine recharge mechanisms in a fractured Brule Formation setting. The surface area of each study reach was estimated by tracing the canal outlines from aerial photography and calculating the area in a geographic information system (GIS) at a scale of 1:1,500. Field identifiers and locations of the streamflow-gaging stations and temperature monitoring sites are listed in table 1.

The study reach of Tri-State Canal had two streamflowgaging stations and two temperature monitoring sites along its length. Streamflow-gaging stations TSUS (Tri-State Canal near Mitchell, Nebr., site 415812103493701) and TSDS (TriState Canal near Mintle, Nebr., site 415626103434001) were established in 2007 at upstream and downstream locations, respectively, along the study reach of Tri-State Canal (fig. 2). Based on GIS analysis of aerial photography, the study reach is $14.2 \mathrm{~km}$ long with an area of $32 \mathrm{ha}$. Within this reach, outflows include six minor laterals (turnouts) and one major lateral diversion; inflows include nine center-pivot return flows, two drainage ditch return flows, and flow received from Spottedtail Creek. Streamflow data for each streamflowgaging station are stored in the publicly accessible USGS National Water Information System (NWIS) database (http:// waterdata.usgs.gov/ne/nwis). Temperature monitoring sites were installed within this reach at site TCTEMP1 (Tri-State Canal near Mitchell, Nebr., site 415542103455301, fig. 2), established in 2007, and site TCTEMP2 (Tri-State Canal at Spottedtail Creek, Nebr., site 415834103483701, fig. 2), established in 2009. All continuous temperature and waterlevel data for the temperature monitoring sites are stored in the publicly accessible NWIS database.

The study reach of Interstate Canal had two streamflowgaging stations and one temperature monitoring site along its length. Streamflow-gaging stations ISUS (Interstate Canal near Rattlesnake Hill, Nebr., site 420327103464301) and ISDS (Interstate Canal near Mintle, Nebr., site 415922103404801) were established in 2007 at upstream and downstream locations, respectively (fig. 2). Based on GIS analysis of aerial photography the study reach is $14.5 \mathrm{~km}$ long with an area of 28 ha. Within this reach outflows include 17 turnouts and two major lateral diversions; inflows include one drainage culvert. Site ICTEMP (Interstate Canal near University Lake, Nebr.,

Table 1. Field names and locations of streamflow-gaging stations and temperature monitoring sites.

[Datum used NAD83, North American Datum of 1983; temperature refers to temperature monitoring site; streamgage refers to streamflow-gaging station; all sites are in Nebraska]

\begin{tabular}{|c|c|c|c|c|c|}
\hline Site name & Site number & Field identifier & Site location & Site type & $\begin{array}{c}\text { Year } \\
\text { established }\end{array}$ \\
\hline \multicolumn{6}{|c|}{ Tri-State Canal } \\
\hline Tri-State Canal near Mitchell & 415812103493701 & TSUS & $41^{\circ} 58^{\prime} 12^{\prime \prime} \mathrm{N}, 103^{\circ} 49^{\prime} 37^{\prime \prime} \mathrm{W}$ & streamgage & 2007 \\
\hline Tri-State Canal near Mintle & 415626103434001 & TSDS & $41^{\circ} 56^{\prime} 26^{\prime \prime} \mathrm{N}, 103^{\circ} 43^{\prime} 40^{\prime \prime} \mathrm{W}$ & streamgage & 2007 \\
\hline Tri-State Canal near Mitchell & 415542103455301 & TCTEMP1 & $41^{\circ} 55^{\prime} 42^{\prime \prime} \mathrm{N}, 103^{\circ} 45^{\prime} 53^{\prime \prime} \mathrm{W}$ & temperature & 2007 \\
\hline Tri-State Canal at Spottedtail Creek & 415834103483701 & TCTEMP2 & $41^{\circ} 58^{\prime} 34^{\prime \prime} \mathrm{N}, 103^{\circ} 48^{\prime} 37^{\prime \prime} \mathrm{W}$ & temperature & 2009 \\
\hline \multicolumn{6}{|c|}{ Interstate Canal } \\
\hline Interstate Canal near Rattlesnake Hill & 420327103464301 & ISUS & $42^{\circ} 3^{\prime} 27^{\prime \prime} \mathrm{N}, 103^{\circ} 46^{\prime} 43^{\prime \prime} \mathrm{W}$ & streamgage & 2007 \\
\hline Interstate Canal near Mintle & 415922103404801 & ISDS & $41^{\circ} 59^{\prime} 22^{\prime \prime} \mathrm{N}, 103^{\circ} 40^{\prime} 48^{\prime \prime} \mathrm{W}$ & streamgage & 2007 \\
\hline Interstate Canal near University Lake & 420233103441301 & ICTEMP & $42^{\circ} 2^{\prime} 33^{\prime \prime} \mathrm{N}, 103^{\circ} 44^{\prime} 13^{\prime \prime} \mathrm{W}$ & temperature & 2008 \\
\hline
\end{tabular}


site 420233103441301 , fig. 2) is a temperature monitoring site that was established in 2008. All streamflow, continuous temperature, and water-level data for the streamflow-gaging stations and temperature monitoring sites are stored in the publicly accessible NWIS database.

\section{Mass-Balance Approach Calculation}

Flow loss attributed to canal leakage was calculated using a mass-balance approach. In addition to the computed daily mean discharge from streamflow-gaging stations, other data were incorporated to compute canal leakage, including daily pan-evaporation rates from the Lake Minatare weather station (fig. 1; Bureau of Reclamation station WMNE, 2009), outflow diversions from the study reach as reported by Pathfinder and Farmers Irrigation Districts (Dennis Strauch, Pathfinder Irrigation District; Kevin Adams, Farmers Irrigation District; unpub. data, 2010), and daily discharge reported for the Spottedtail Creek streamflow-gaging station (fig. 2; Bureau of Reclamation station WSNE, 2009). Equations (2) and (3) quantify how daily mean leakage rates were calculated for each canal reach.

$$
\begin{aligned}
{\left[\left(Q_{U}-D-E_{p}+W\right)-Q_{D}\right] / A=\underset{\text { daily mean leakage rate for }}{\text { Tri-State Canal, in } \mathrm{m} / \mathrm{d}} } &
\end{aligned}
$$

$$
\begin{aligned}
{\left[\left(Q_{U}-D-E_{p}\right)-Q_{D}\right] / A=} & \text { daily mean leakage rate from } \\
& \text { Interstate Canal, in } \mathrm{m} / \mathrm{d}
\end{aligned}
$$

where,

$Q_{U}$ is the upstream daily mean discharge, in cubic meters per second,

$D$ is the sum of reported outflow diversions from the study reach, in cubic meters per second,

$E_{p}$ is the daily pan evaporation, in meters/day

$W$ is the reported daily mean discharge from Spottedtail Creek, in cubic meters per second,

$Q_{D}$ is the downstream daily mean discharge, in cubic meters per second,

$A$ is the estimated area (of the bed) of the study reach, in square meters, and irrigation drainage return flows are neglected.

\section{Data Sources}

Total daily evaporation was estimated using the reported pan evaporation rate from station WMNE multiplied by the estimated canal area for each reach and converted to daily average water loss in cubic meters per second. The Spottedtail Creek streamflow-gaging station is located $1.5 \mathrm{~km}$ upstream from Tri-State Canal. There may be differences between discharge reported at the streamflow-gaging station and the actual discharge from Spottedtail Creek into the canal. This could introduce some error into leakage estimates, especially in wet-weather conditions where intervening surface runoff and increased groundwater discharge would increase the discharge downstream from the streamflow-gaging station. Flow received from drainage returns was assumed to be minimal and to occur during short periods of wet-weather conditions, and, therefore, was not considered in the leakage calculation.

The reach area used in the leakage calculations was the planimetric (map view) area rather than the wetted perimeter of each canal. The calculated map view area was more appropriate because most of the study reach of each canal was constructed well above the water table, and in some cases the canal banks were constructed above the original land surface; therefore, leakage from irrigation canals results in predominantly vertical water flow.

Precipitation was recorded every 15-minutes at the upstream streamflow-gaging station within each study reach only when streamflow-gaging stations ISUS and TSUS were active. Precipitation would have been such a small component that it was not used in the mass-balance calculation. Recorded precipitation was used to assess local climatic conditions and the possibility when unmeasured flow from drainage returns or other unmeasured inputs could increase errors in leakage calculations. Measured precipitation also was examined to provide additional climatic context when using the recorded precipitation reported at the Scottsbluff Airport by the National Oceanic Atmospheric Administration National Climatic Data Center (http://gis.ncdc.noaa.gov/website/ ims-cdo/sod/viewer.htm, accessed March 1, 2010).

\section{Hydroacoustic Data Collection and Index- Velocity Computation}

The methods of collecting and computing discharge have improved significantly since the U.S. Geological Survey began collecting streamflow data in 1889. Recent developments in the area of streamflow-monitoring technology have enhanced the quality of the data collected and the confidence in streamflow computation. Using sound waves, hydroacoustic instruments are capable of measuring the magnitude and direction of water velocity across an entire stream profile or part of the water column. These instruments emit an acoustic pulse at a known frequency. As the pulse travels horizontally and vertically through the water column a part of the emitted energy is reflected off particles (scatter) in the water and back to the instrument. Using the Doppler-shift principle, water speed and direction of flow are calculated by assessing the change in frequency of the returning pulse (Morlock and others, 2002).

For this study, acoustic Doppler velocity meters (ADVMs) were secured within the surface-water column to measure water velocity and level (stage). Data collected from ADVMs were used in conjunction with independent acoustic Doppler current profiler discharge measurements to compute discharge. The ADVMs were oriented to emit a 2-beam horizontal signal to define water velocity and direction, and a single vertical beam to determine stage. 
The ADVM-measured water velocity was sampled in 10 cells, which are user-specified increments of the stream cross-section.

Sontek 1500 kHz Argonaut SL (YSI Sontek, San Diego, Calif.) ADVMs were deployed at upstream and downstream ends of each study reach. The Sontek Argonaut has a reported velocity measuring accuracy of $0.001 \mathrm{~m} / \mathrm{s}$. The ADVMs were secured to the end of a steel I-beam angled down the bank into the water column and oriented such that the vertical beam was perpendicular to the water surface. With this deployment configuration the ADVMs were not able to collect stage and velocity data at low-flow stages. ADVMs needed at least $0.15 \mathrm{~m}$ of water above the vertical beam to accurately measure stage.

Discharge is computed from cross-sectional area and velocity (Rantz, 1982). To compute discharge using an ADVM, the stage-dependant cross-sectional area must be established. Before each irrigation season a stage-area relation was defined by using a conventional leveling survey to measure distance and elevation across the channel at each ADVM deployment location. Level surveys were done annually to assess potential changes in the channel geometry that may have occurred during the previous irrigation season, because routine channel maintenance may affect the stage-area relation. The level survey data was processed with a USGS program, AreaComp (Rehmel, 2002), to determine the stage to cross-sectional area relation. Staff gages were installed at each streamflow-gaging station to allow verification of the ADVM recorded stage readings.

The ADVMs were programmed to measure and record stage and velocity at 15-minute intervals. Velocity data were averaged over a 3-minute interval before recording. Horizontal water velocity typically was sampled in ten $0.91-\mathrm{m}$ cells across the channel. After canal diversions began, a beam check was run to verify that no obstructions were in the cross-section that could bias the velocity data. All data collected were logged on the internal memory of the ADVM and an external data collection platform (DCP). Logged DCP data were transmitted hourly through the Geostationary Operational Environmental Satellites (GOES). The uploaded data were then stored in publicly accessible NWIS-Web (http://waterdata.usgs.gov/nwis).
Acoustic Doppler current profilers (ADCPs) were used independently to measure the discharge of each canal. Individual ADCP measurements were collected for a range of stages (Morlock and others, 2002). The ADCP used was a Teledyne RD Instruments (Poway, Calif.) $1200 \mathrm{kHz}$ Rio Grande, with reported accuracy of 0.25 percent of the measured velocity. The ADCP was mounted to a measuring catamaran tethered to a pulley system spanning the canal at each streamflow-gaging station. Summary statistics for ADCP measurements collected at each streamflow-gaging station, including percent difference between measured and computed discharge, are summarized in table 2.

To collect a complete velocity profile, the instrument was moved across the channel, perpendicular to the principal direction of flow. The water velocity was sampled in cells that were integrated to determine the total discharge for a single measurement (velocity times area, summed for all cells). The reported total discharge for an independent ADCP measurement was the mean discharge calculated from at least four velocity profiles or transects. If any of the transects were not within 5 percent of the computed mean, then four more transects were collected before the mean discharge was calculated and reported. For a more thorough discussion of using ADCP procedures for measuring discharge including field data collection and processing, refer to Mueller and Wagner (2009).

Computing discharge from recorded ADVM velocity and stage measurements and independent ADCP measurements requires the application of the index-velocity method. This index-velocity method of calculating stream discharge relies on the assumed relation between the current velocity of some specific increment of the stream cross-section and the total stream discharge. To compute discharge the indexed velocity is multiplied by the stage-dependant cross-sectional area to determine the total discharge. The accuracy of each indexvelocity rating depends on multiple factors including: stability of the channel geometry at the site, the accuracy of the crosssectional area measurement, accuracy of stage and velocity measurements, and accuracy of the independent discharge measurements (Morlock and others, 2002). The development of the index-velocity ratings and the discharge computation was completed in accordance with the methods and guidelines

Table 2. Summary statistics for Acoustic Doppler Current Profiler (ADCP) measurements including percent difference between ADCP and computed discharge from Tri-State Canal and Interstate Canal streamflow-gaging stations, 2007-09.

[ADCP, Acoustic Dopper Current Profiler; discharge is given in cubic meters per second; ABS, absolute value]

\begin{tabular}{|c|c|c|c|c|c|c|c|}
\hline \multirow{2}{*}{ Field identifier } & \multirow{2}{*}{$\begin{array}{l}\text { Number of ADCP } \\
\text { measurements }\end{array}$} & \multicolumn{3}{|c|}{ Discharge, measured by ADCP } & \multicolumn{3}{|c|}{$\begin{array}{l}\text { ABS percent difference between the measured } \\
\text { ADCP and computed discharge }\end{array}$} \\
\hline & & Maximum & Minimum & Median & Maximum & Minimum & Median \\
\hline TSUS & 15 & 35.6 & 13.4 & 23.8 & 3.96 & 0.21 & 1.62 \\
\hline TSDS & 15 & 34.8 & 13.4 & 29.2 & 4.14 & .34 & 1.63 \\
\hline ISUS & 26 & 24.3 & 9.20 & 17.2 & 4.57 & .13 & 1.93 \\
\hline ISDS & 21 & 20.4 & 11.4 & 15.6 & 5.55 & .02 & 1.79 \\
\hline
\end{tabular}


reported in Mueller and Wagner (2009) and Morlock and others (2002).

\section{The Use of Heat as a Tracer}

The effectiveness of using heat as a tracer in groundwater and surface-water interaction studies has been well established. Heat tracer techniques have been applied successfully to determine streambed hydraulic conductivity (Essaid and others, 2007; Eddy-Miller and others, 2009; Zamora, 2008), assess diurnal and annual variability in groundwater/surfacewater exchanges (Cox and others, 2007; Ronan and others, 1998), and determining groundwater recharge from ephemeral streams (Constantz and others, 2002). The practicality of using heat as a tracer has improved substantially in recent years because of improvements in data-collection equipment and computational capabilities (Stonestrom and Constantz, 2003). For more detail on the use of this technique in studies of groundwater and surface-water interaction and groundwater transport refer to Stonestrom and Constantz (2003), Andersen (2006), Blasch and others (2007), Constantz and others (2002), and Constantz (2008).

\section{VS2DH Model Framework and Calibration}

Numerical modeling of continuous sediment temperature data allows canal leakage to be quantified. The groundwater flow and transport model VS2DH (Healy and Ronan, 1996) was used to simulate flow and estimate the vertical hydraulic conductivity of the canal-bed sediment at the temperature monitoring sites. VS2DH is a finite-difference model that uses a modified version of the advection-dispersion equation expressed in terms of water temperature (Healy and Ronan, 1996). Flow through the unsaturated zone is solved using a modified version of the Richards equation (Chow and others, 1988) that assumes hydraulic conductivity is a temperaturedependent variable because of viscosity effects. VS2DH required continuous records of the water temperature, canal stage, groundwater level, and sediment temperature at multiple depths beneath the canal bed (Stonestrom and Constantz, 2003). A one-dimensional grid was created, with the top of the grid representing canal-bed water interface with changing temperature and stage. Model parameters, such as hydraulic conductivity, were adjusted, such that, the timing and amplitude of the diurnal temperature peaks of the simulated temperatures matched measured temperatures. Estimated canal leakage was the calculated flux determined from the best-fit model.

Creating a useful VS2DH model involves specifying a model domain and boundary conditions that adequately represent the physical system at each temperature monitoring site. The physical characteristics of the model were based on a number of data sources collected at each site, including continuous sediment cores, CCR profiles, continuous water temperature, and water-level data. One-dimensional VS2DH models were constructed for each temperature monitoring site based on flow through canal-bed sediment that was assumed to be primarily vertical. With this configuration, non-vertical (referred to hereinafter as multidimensional) flow of water was ignored, and only the vertical hydraulic conductivity of the shallow bed sediment was estimated. The top boundary of the model was at the canal-bed water interface and was assigned specific-head and specific-temperature boundary conditions based on measured canal stages and canal water temperatures. The bottom boundary was assigned specific-head and specifictemperature conditions on the basis of recorded groundwater levels and temperatures. The sides of the model domain were specified as no flow boundaries. Model domains thus were to represent the subsurface from the canal-bed surface to the groundwater table before the irrigation season. The thickness of model domains were based on elevation data collected at each site with a real time kinematic global positioning system (RTK GPS) with a vertical precision of plus or minus ( \pm ) 5 $\mathrm{cm}$. A generalized one-dimensional VS2DH model is shown in figure 4.

Model domains for each VS2DH model were subdivided into a series of rows each assigned a sediment texture on the basis of described lithology of continuous sediment cores collected at each temperature monitoring site. Lithologic descriptions of collected sediment cores are included in appendix 1 of this report. Estimates of thermal and hydraulic properties, such as thermal conductivity of saturated sediment, porosity, and heat capacity of water, were based on published values from Niswonger and Prudic (2003) and Healy and Ronan (1996). Thermal properties were held constant for all the sediment textures used in each simulation and are summarized in table 3 .

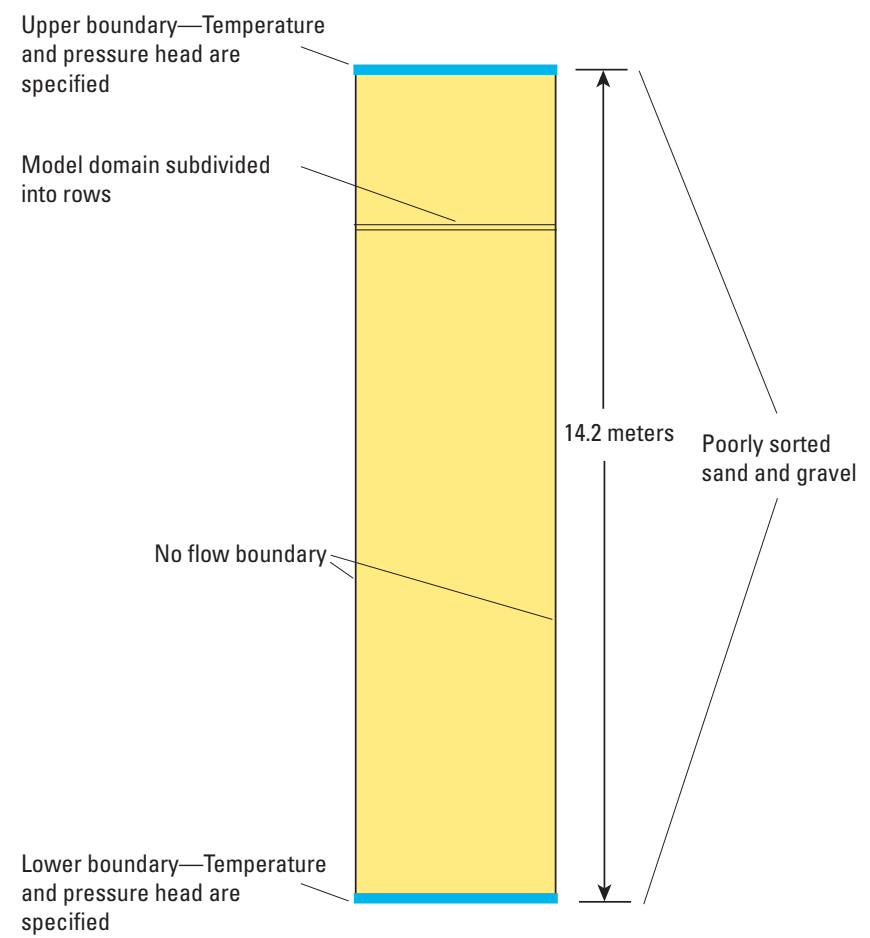

Figure 4. Generalized one-dimensional VS2DH model of water and heat transport through canal-bed sediment. 
Table 3. Summary of hydraulic and thermal properties used in final VS2DH models for each temperature monitoring site.

$\left[\mathrm{cm}^{3}\right.$, cubic centimeters; $\mathrm{W} / \mathrm{m}{ }^{\circ} \mathrm{C}$, watts per meter degrees Celsius; $\mathrm{J} / \mathrm{m}^{3}{ }^{\circ} \mathrm{C}$, Joules per cubic meter degrees Celsius; $\mathrm{m} / \mathrm{d}$, meters per day]

\begin{tabular}{|c|c|c|c|c|}
\hline Sediment texture & $\begin{array}{l}\text { Porosity } \\
\left(\mathrm{cm}^{3} / \mathrm{cm}^{3}\right)\end{array}$ & $\begin{array}{l}\text { Thermal conductivity of } \\
\text { saturated sediment }{ }^{2} \\
\left(\mathrm{~W} / \mathrm{m}^{\circ} \mathrm{C}\right)\end{array}$ & $\begin{array}{c}\text { Heat capacity of } \\
\text { water }{ }^{3} \text { at } 20^{\circ} \mathrm{C} \\
\left(\mathrm{J} / \mathrm{m}^{3}{ }^{\circ} \mathrm{C}\right)\end{array}$ & $\begin{array}{c}\text { Modeled vertical } \\
\text { hydraulic conductivity } \\
(\mathrm{m} / \mathrm{d})\end{array}$ \\
\hline \multicolumn{5}{|c|}{ TCTEMP1 } \\
\hline Poorly sorted sand and gravel & 0.375 & $2.1 \times 10^{6}$ & $4.2 \times 10^{6}$ & 1.1 \\
\hline Silt loam & .43 & $2.1 \times 10^{6}$ & $4.2 \times 10^{6}$ & .17 \\
\hline \multicolumn{5}{|c|}{ TCTEMP2 } \\
\hline Medium sand & .375 & $2.1 \times 10^{6}$ & $4.2 \times 10^{6}$ & 17 \\
\hline Fine sand & .375 & $2.1 \times 10^{6}$ & $4.2 \times 10^{6}$ & 1.1 \\
\hline \multicolumn{5}{|c|}{ ICTEMP } \\
\hline Medium sand & .375 & $2.1 \times 10^{6}$ & $4.2 \times 10^{6}$ & 17 \\
\hline Fine sand & .375 & $2.1 \times 10^{6}$ & $4.2 \times 10^{6}$ & 2.1 \\
\hline Silt and weathered Brule & .43 & $2.1 \times 10^{6}$ & $4.2 \times 10^{6}$ & .69 \\
\hline
\end{tabular}

${ }^{1}$ From Lapalla and others, 1987.

${ }^{2}$ From Healy and Ronan, 1996.

${ }^{3}$ From Niswonger and Prudic, 2003.

Porosity values were estimated based on published values documented by Lapalla and others (1987) and are summarized in table 3.

All irrigation seasons were divided into 15- or 30-minute intervals called recharge periods, each having unique upper and lower boundary conditions based on measured water-level and water temperature data. Start date for model simulation periods for each temperature monitoring site was indicated for each irrigation season by a recorded rise in groundwater levels. This rise was interpreted to signal that shallow sediment was saturated and flow predominantly was vertical. Model estimates of the vertical hydraulic conductivity of the canal-bed sediment involved a trial-and-error approach to obtain the best fit between the simulated and measured sediment temperature profiles. After each model simulation, the simulated temperatures from user-specified observation points were plotted and visually compared to the measured data from each corresponding depth. The vertical hydraulic conductivity of the modeled sediment textures was adjusted between simulations (trials) until the timing and amplitude of the diurnal temperature peaks agreed between the simulated and measured temperatures. The estimated average vertical hydraulic conductivity of each canal-bed sediment texture is reported from the best-fit model for each temperature monitoring site (table 3 ).

\section{Monitoring Design and Data Collection}

\section{Tri-State Canal near Mitchell, Nebr.}

Using CCR profiles and continuous sediment cores, Ball and others (2006) reported that underlying Tri-State Canal near temperature monitoring site TCTEMP1 is approximately
$15 \mathrm{~m}$ of unsaturated poorly sorted sand and gravel. Vertical sensor arrays were installed at various locations across the canal bed to examine potential differences in measured temperatures with different sensor deployment designs.

Sediment temperature gradients were determined by measuring temperature at multiple depths beneath the canal in separate vertical sensor arrays. Sediment temperature data were collected with a subset of type-E thermocouples in four vertical sensor arrays. All thermocouple junctions were soldered together and covered with heat shrink tubing to insulate the junction from the environment. A direct-push Geoprobe ${ }^{\circledR}$ (Salina, Kans.) coring rig collected a sediment core at the location of each vertical sensor array. Vertical sensor arrays 1 and 2 were installed inside two open $6.1-\mathrm{m}$ long, 2.5-cm diameter polyvinyl chloride (PVC) pipes, and arrays 3 and 4 were installed inside of two 3.05-m open holes in direct contact with the sediment. Vertical sensor arrays 1 and 2 collected sediment temperature data at $0.15,0.38,0.76$, 1.52 , and $3.05 \mathrm{~m}$ below the canal-bed surface, and vertical sensor arrays 3 and 4 collected sediment temperature data at $0.15,0.23,0.38,0.76$, and $1.52 \mathrm{~m}$ below the canal-bed surface. All sensor arrays were backfilled with native material after installation. Thermocouples were connected to two Campbell Scientific ${ }^{\circledR}$ (Logan, Utah) CR10X data loggers housed inside a steel enclosure at the top of the canal bank. The data loggers were placed inside a styrofoam cooler and wrapped in bubble wrap to reduce the effects of temperature gradients that could develop on the wiring panel of the data logger.

Although Type-E thermocouples have 1.0 degrees Celsius $\left({ }^{\circ} \mathrm{C}\right.$ ) accuracy for a 0 to $900{ }^{\circ} \mathrm{C}$ temperature range (Omega Engineering, 2008), diurnal temperature noise as large as $2{ }^{\circ} \mathrm{C}$ was present in measured data in all thermocouples. This noise is the result of temperature gradients that develop along the 
thermocouple wire and on the wiring panel of the data logger. To reduce diurnal noise, a reference thermistor replaced one of the thermocouples on the wiring panel on each data logger, so that the thermocouples referenced this thermistor rather than a thermistor remote from the wiring panel. Data from the deepest subsurface thermocouples indicated that this modification decreased the diurnal temperature noise to $0.3^{\circ} \mathrm{C}$. To remove any artificial diurnal temperature variations, all thermocouple data were post-processed using a technique described by Mihevc and others (2002) and Hobza (2008). This technique assumes that temperature changes in sediment near the deepest thermocouple are the result of seasonal warming and cooling. Any diurnal temperature variations in the measured data for the deepest thermocouple are considered to be artificial, and are the result of temperature gradients that have developed on the wiring panel of the data logger. To correct for the artificial diurnal variation, daily temperature data recorded by the deepest thermocouple at 4:00 a.m. were fit with a series of polynomial functions. Data measured at 4:00 a.m. were chosen because this is when temperature gradients on the data logger wiring panel are assumed to be the smallest. The difference between the measured data from the deep thermocouple and the fitted data was calculated for each time step. This difference was subtracted from all other thermocouple data from the same vertical array to produce data sets with minimal noise. An example of pre-processed, unfiltered and post-processed, filtered temperature data is shown in figure 5.

To collect data sets free of artificial diurnal noise, and assess the effectiveness of the thermocouple data post-processing, additional sediment temperature data were collected with HOBO® Tidbit temperature loggers for the 2008 and 2009 irrigation seasons. The HOBO® Tidbit temperature logger (Onset Computer Corp., Pocasset, Mass.) is a self-logging thermistor accurate to $\pm 0.2^{\circ} \mathrm{C}$ within a -5 to $37^{\circ} \mathrm{C}$ temperature range (Onset Computer Corp., http://www.onsetcomp.com/ products/data-loggers/tbi32-0537). Self-logging thermistors measure an electrical resistance which is dependent on the temperature of the surrounding environment and do not require an external reference temperature (Stonestrom and Blasch, 2003). HOBO® temperature loggers were deployed inside of a stainless-steel sand point and were suspended at depths corresponding to the some of the depths of the subsurface data collected by the thermocouples in all four vertical sensor arrays.

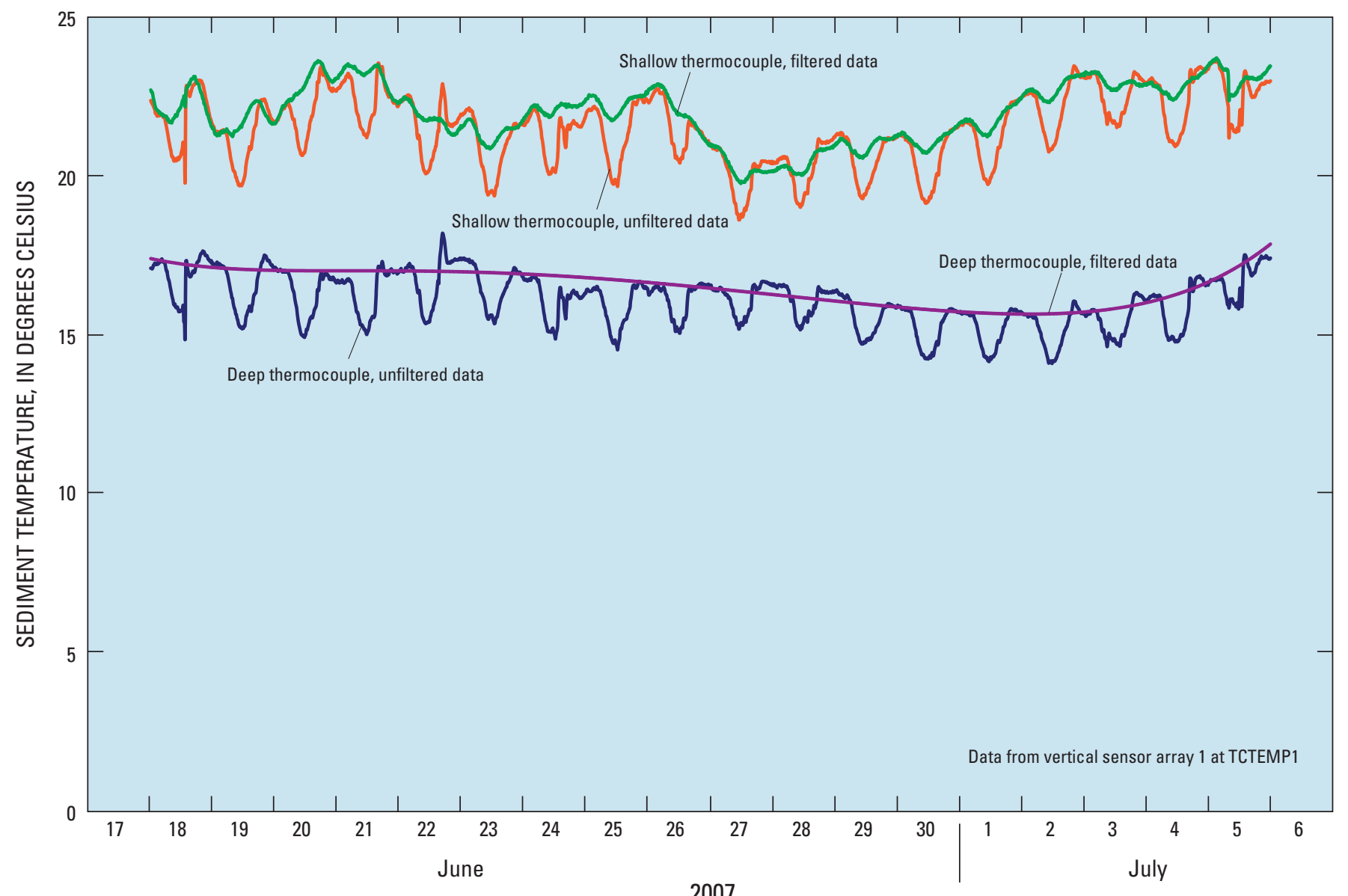

Figure 5. Example subsurface temperature data from paired deep and shallow thermocouples: pre-processed, unfiltered data display an artificial diurnal variation, and post-processed, filtered data have had artificial diurnal variation removed. 
In addition to sediment temperature data, canal water temperature data were measured during each irrigation season. A HOBO ${ }^{\circledR}$ Tidbit temperature logger was deployed inside of a section of pipe anchored to the bed of the canal. Following its disturbance July 7, 2008, the HOBO temperature logger ceased operation for the remainder of the 2008 irrigation season.

Canal-stage data were collected using an In-situ LevelTROLL $^{\circledR} 500$ (In-Situ Inc., Fort. Collins, Colo.) vented-cable transducer located inside a stilling well. The transducer was placed $0.76 \mathrm{~m}$ above the elevation of the canal bed. A monitoring well was installed near the temperature monitoring site and instrumented with a second In-situ Level-TROLL ${ }^{\circledR} 500$ to continuously record groundwater levels. In-situ Level-Troll 500 pressure transducers are accurate to $0.02 \mathrm{~m}$ (In-situ Inc., http:// www.in-situ.com/products/Water-Level/Level-TROLL-Family/ Level-TROLL-500-Instrument/overview). Manual water-level measurements were collected to verify the accuracy of the groundwater-level record. All continuous data collected at this site were recorded at 15-minute intervals throughout the duration of the study. A generalized diagram and map of the installation design for site TCTEMP1 is shown in figure 6.

The VS2DH model domain extended from the elevation of the top of the canal bed to the water table elevation immediately before canal diversion for the hay run and primary irrigation seasons. The model domain varied slightly depending on the elevation of the water table before diversion into Tri-State Canal. The entire model domain was subdivided into 500 rows and was assigned a single lithologic unit composed of poorly sorted sand and gravel based on data from continuous sediment cores (appendix 1), CCR data, and a test-hole log recorded during monitoring-well installation. The irrigation season was subdivided into 15-minute periods called recharge periods that had unique upper and lower boundary conditions. Canal-stage and water temperature data were inputs for the upper boundary condition of each model simulation. Differences between the elevation of the canal bed and the elevation of the stage transducer were added to the stage record to determine the pressure head at the canal-bed surface. Continuous groundwater-level and groundwater-temperature data were inputs for the lower boundary condition of each model simulation. The difference between the pre-diversion groundwater-level elevation and recorded groundwater elevation was the pressure head exerted at the lower model boundary for each recharge period.

\section{Tri-State Canal at Spottedtail Creek, Nebr.}

Site TCTEMP2 was located immediately downstream from the confluence of Tri-State Canal with Spottedtail Creek where discharge received from Spottedtail Creek submerges the canal bed, and it potentially creates a groundwater mound beneath the canal. Within this reach the higher water table would decrease the hydraulic gradient and potentially reduce canal leakage. This condition is believed to be spatially anomalous as most of the reach is dry during the non-irrigation season. The headwaters of Spottedtail Creek are south of Interstate Canal, approximately $8 \mathrm{~km}$ upstream from Tri-State Canal. The Bureau of Reclamation operates a streamflowgaging station about $1.5 \mathrm{~km}$ above site TCTEMP2. Leakage from Interstate Canal increases local groundwater levels and contributes to the base flow of Spottedtail Creek (Harvey and Sibray, 2001). Historical discharge data indicate that Spottedtail Creek is an intermittent stream at the streamflowgaging station; however, discharge was continuous for the site TCTEMP2 period of record.

Site TCTEMP2 was designed to measure the shallow groundwater level beneath Tri-State Canal in order to compute the hydraulic gradient. Canal-stage data were collected using an In-situ Level-TROLL ${ }^{\circledR} 100$ nonvented transducer deployed inside of a 0.2-m long section of PVC pipe attached to the sounding weight. Pressure-head data were collected with an In-situ Level-TROLL ${ }^{\circledR} 100$ nonvented transducer deployed in a stainless-steel sand point $0.91-\mathrm{m}$ below the canal bed. The cap of the sand point was sealed water tight, and the sandpoint screen was covered with pipe wrap except for the bottom $0.15 \mathrm{~m}$, which was open to the canal-bed sediment. The distance between the transducers was $0.91 \mathrm{~m}$ and was assumed to remain fixed. Data collected from both nonvented transducers were corrected for changes in barometric pressure as monitored using an In-situ Baro-TROLL pressure sensor. The calculated accuracy of both nonvented transducers after barometric pressure correction is $\pm 0.03 \mathrm{~m}$ (In-situ Inc., http://www. in-situ.com/products/Water-Level/BaroTROLL-Instruments/ Rugged-BaroTROLL-Instrument/overview). Sediment temperature data were collected with $\mathrm{HOBO}^{\circledR}$ TidbitV2 temperature loggers $\left( \pm 0.2^{\circ} \mathrm{C}\right.$ in a 0 to $50{ }^{\circ} \mathrm{C}$ range; Onset Computer Corp., http://www.onsetcomp.com/products/data-loggers/utbi001) deployed inside of a stainless-steel sand point at depths of $0.15,0.23,0.38$, and $0.76 \mathrm{~m}$ below the canal-bed surface. Water temperature was collected with a $\mathrm{HOBO}{ }^{\circledR}$ TidbitV2 temperature logger attached to the top of a sounding weight placed on the bed of the canal to ensure the temperature logger remained in the water column. Continuous sediment cores were collected by manually driving a Geoprobe ${ }^{\circledR}$ core barrel into the saturated sediment to a depth of $0.91 \mathrm{~m}$ beneath the canal-bed surface. A generalized diagram and map of the installation design used at site TCTEMP2 is shown in figure 7.

A one-dimensional VS2DH model was created using the continuous sediment core (appendix 1), and the waterlevel and water temperature data collected from May through September 2009. The model domain was subdivided into 200 rows and extended from the top of the canal bed to the level of the lower transducer. Stage and canal water temperature data were inputs for defining the upper boundary condition of each model simulation. Continuous pressure-head and groundwater-temperature data were inputs for defining the lower boundary condition of each model simulation. Because the model boundary was set at the location of the lower transducer, the recorded groundwater level was equal to the pressure head exerted at the lower model boundary for each recharge period. 


\section{$\boldsymbol{A}$}

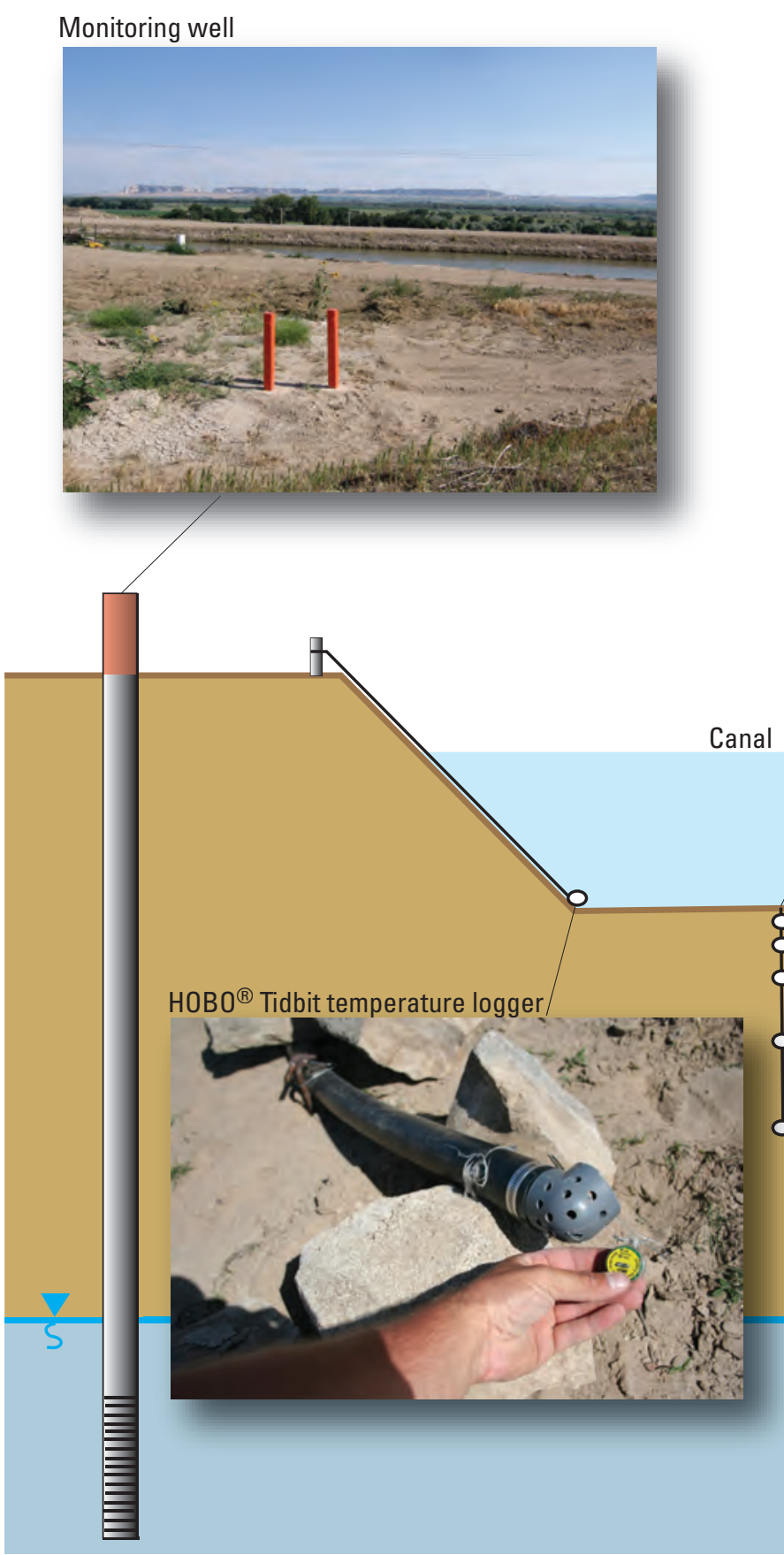

\section{Stilling well}
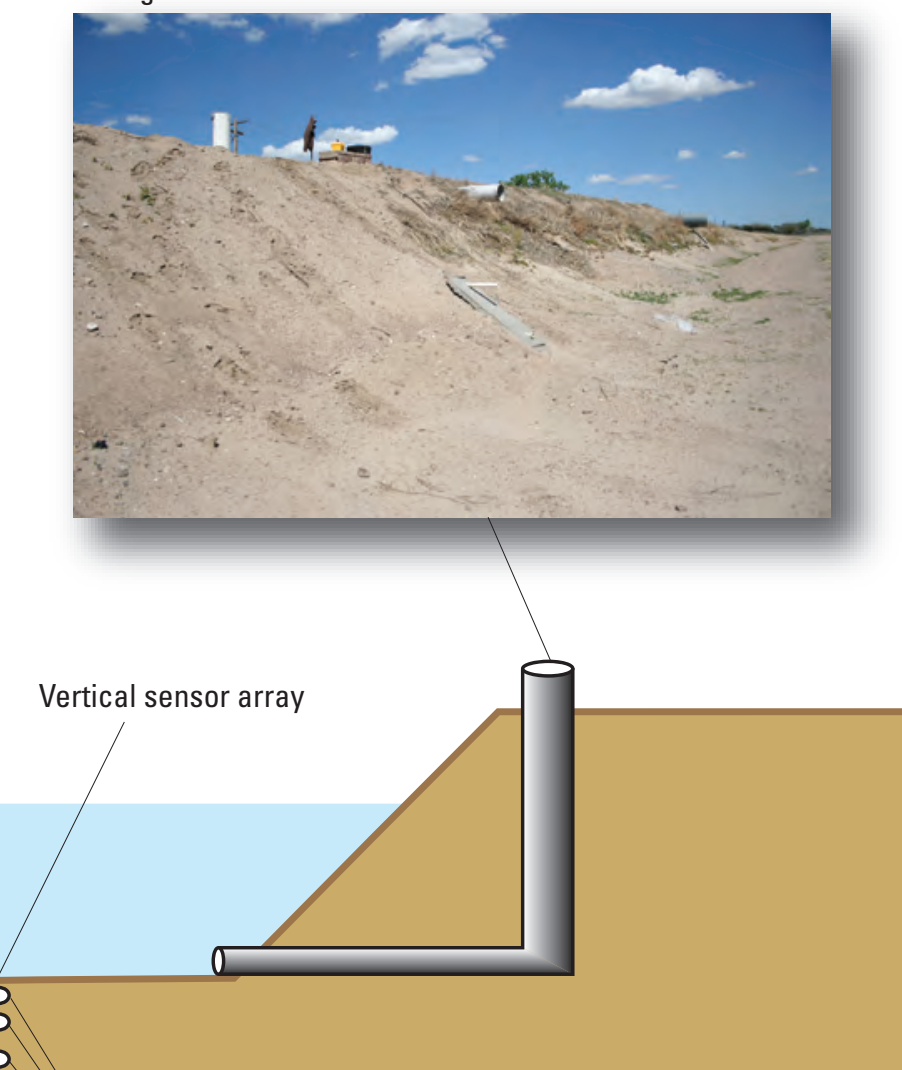

Vertical sensor array
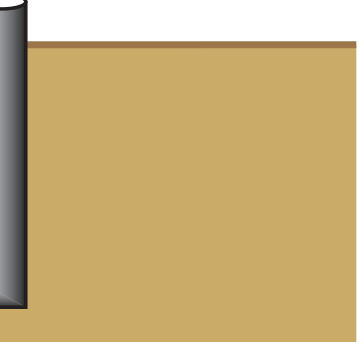

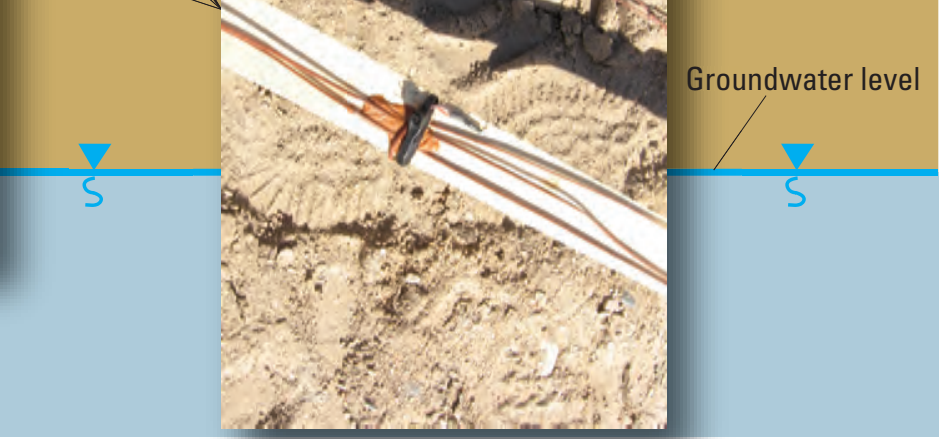

Not to scale

Figure 6. Generalized diagram (A) and map (B) of monitoring installation design used at site TCTEMP1, Tri-State Canal near Mitchell, Nebr.

\section{Interstate Canal near University Lake, Nebr.}

Sediment temperature data were collected with a series of type-T thermocouples (Omega Engineering, 2010) in two vertical sensor arrays beneath the canal bed (VA1 and VA2), and two vertical sensor arrays immediately south of Interstate
Canal (VA3 and VA4) (fig. 8). The placement of the thermocouple sensor arrays was chosen to examine vertical and lateral leakage of canal water. Type-T thermocouples have a reported precision of $\pm 0.5^{\circ} \mathrm{C}$ for a range of temperatures from 0 to $900^{\circ} \mathrm{C}$ (Omega Engineering, 2010). At sensor array VA1, thermocouples collected data $0.15,0.23,0.38,1.52$, and 


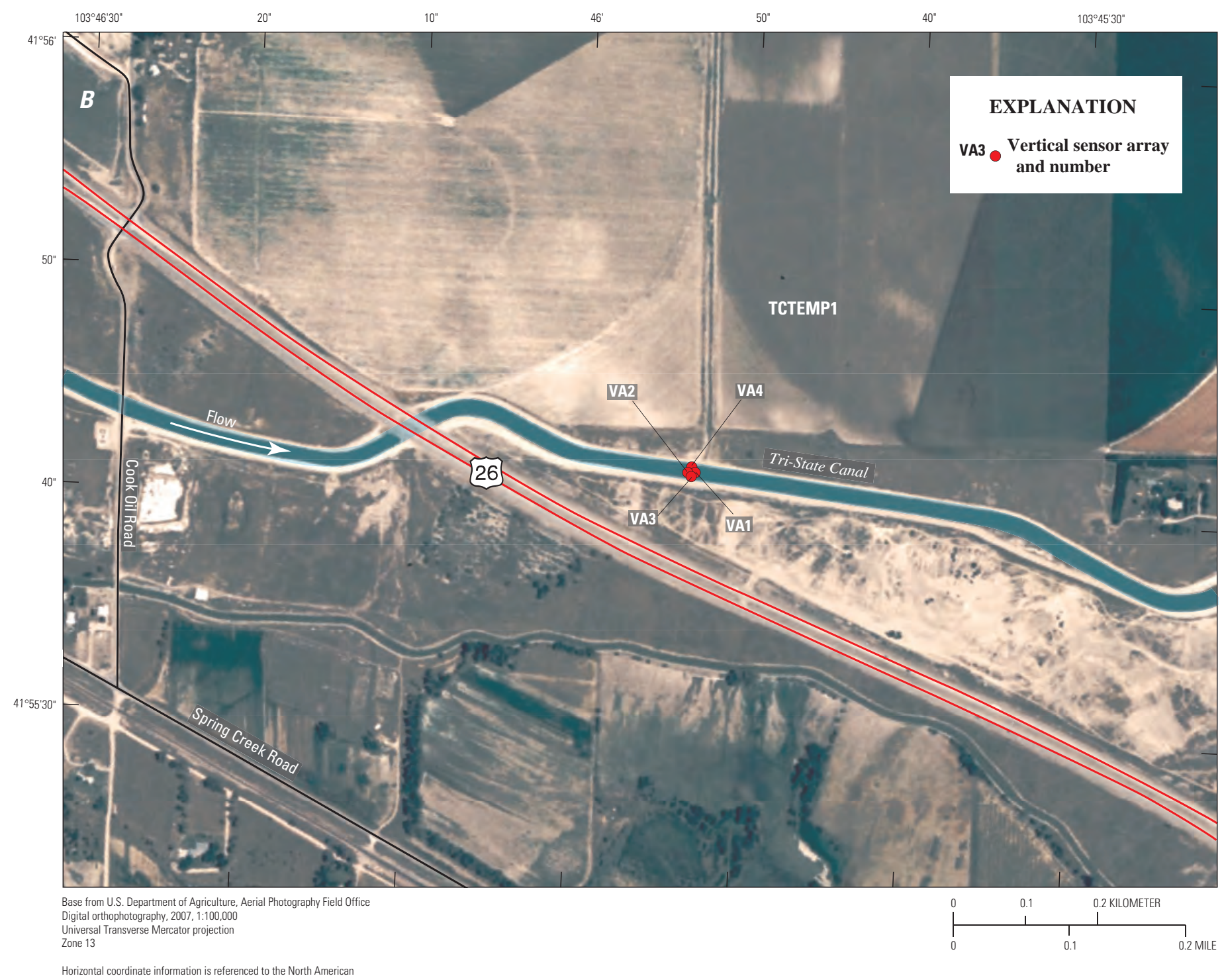

Horizontal coordinate information is referenced to the North American Datum of 1983 (NAD 83)

Figure 6.-Continued.

$4.5 \mathrm{~m}$ below the canal-bed surface. At sensor array VA2, thermocouples collected sediment temperature data at $0.15,0.23$, $0.38,0.61$, and $5.49 \mathrm{~m}$ below the canal-bed surface. South of the canal, thermocouples at sensor array VA3 collected sediment temperature data at 7.01, 7.47, 7.92, 8.38, 8.83, and $9.14 \mathrm{~m}$ below land surface. At sensor array VA4, sediment temperature data were collected at 7.92, 8.53, 8.83, and $9.14 \mathrm{~m}$ below land surface south of the canal.

Boreholes at vertical sensor arrays were backfilled with native material after installation. Sensor arrays were connected to two Campbell Scientific CR10X data loggers housed inside a steel enclosure at the top of the canal bank. Reference 
thermistors were wired to the panels of the data loggers, as for site TCTEMP1. Diurnal temperature noise as large as $0.5^{\circ} \mathrm{C}$ was present in measured data from all thermocouples. These data were adjusted as previously described in Tri-State Canal near Mitchell, Nebr., section of this report. Additional sediment temperature data were collected with HOBO temperature loggers deployed inside of a stainless-steel sand point. These temperature loggers collected sediment temperature at 0.15 , $0.23,0.38$, and $0.76 \mathrm{~m}$ below the canal-bed surface.

Canal water temperature also was monitored continuously. A $\mathrm{HOBO}{ }^{\circledR}$ Tidbit temperature logger was deployed inside of a section of pipe anchored to the bed of the canal. Canal stage data were collected using an In-situ LevelTROLL $® 500$ vented-cable transducer placed inside of a stilling well. A monitoring well was installed near the temperature monitoring location and instrumented with an In-situ LevelTROLL ${ }^{\circledR} 500$ vented-cable transducer to continuously record groundwater levels. Water level also was measured manually to verify the groundwater-level record. Continuous data were recorded at 15-minute intervals throughout the study. A generalized diagram and map of the installation design used at site ICTEMP is shown in figure 8.

A one-dimensional VS2DH model was constructed based on the lithology of the collected sediment cores at site ICTEMP (appendix 1). The model domain was subdivided into 500 rows and comprised three layers corresponding to different sediment types: $0.3 \mathrm{~m}$ of medium sand, overlying $1.0 \mathrm{~m}$ of fine sand, overlying $14.2 \mathrm{~m}$ of silt and weathered Brule Formation (appendix 1). The model domain extended from the top of the canal bed to the water table elevation measured immediately before the start of the 2008 diversions into the canal. The entire irrigation season was divided into 15-minute recharge periods. Inputs defining the upper boundary condition of each simulation were canal stage and canal water temperature data. Inputs defining the bottom boundary condition of each simulation were continuous records of groundwater level and groundwater temperature. The difference in elevation between the pre-diversion groundwater-level elevation and recorded groundwater elevation is the pressure head exerted at the lower boundary for each recharge period.

\section{Calculated Leakage Rates Using Mass- Balance Approach}

\section{Tri-State Canal Leakage Rates}

Daily mean computed discharge from rated ADVM for the TSUS and TSDS streamflow-gaging stations is shown in figures 9 through 11 for a selected period each year. The minimum computed discharge from Tri-State Canal was $13.2 \mathrm{~m}^{3} / \mathrm{s}\left(465 \mathrm{ft}^{3} / \mathrm{s}\right)$, reported at the TSDS streamflow-gaging station on May 16, 2008 (not shown), and the maximum reported discharge was $36.5 \mathrm{~m}^{3} / \mathrm{s}\left(1,290 \mathrm{ft}^{3} / \mathrm{s}\right)$ reported at the
A

Water level

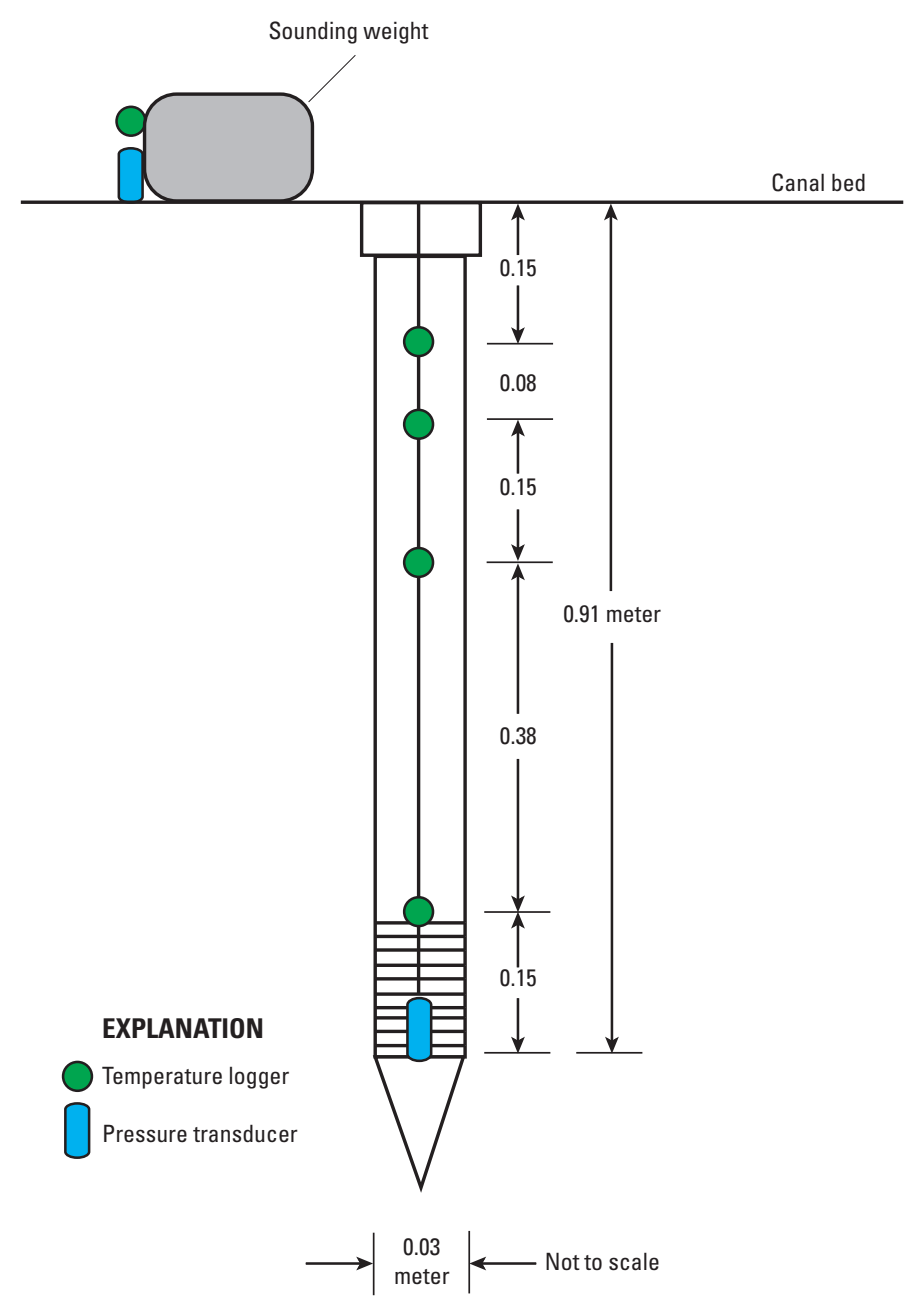

Figure 7. Generalized diagram (A) and map (B) of monitoring installation design used at site TCTEMP2, Tri-State Canal at Spottedtail Creek, Nebr.

TSUS streamflow-gaging station on July 9, 2007. In general, higher flows were reported during the 2007 irrigation season in response to drier conditions and greater demands for irrigation water. Reported daily mean diversions to laterals within the study reach ranged from 0 to $0.19 \mathrm{~m}^{3} / \mathrm{s}\left(0\right.$ to $\left.6.8 \mathrm{ft}^{3} / \mathrm{s}\right)$ and typically were greatest from late July into early August when water demands were greatest. Evaporative water loss was less than 1 percent of the computed daily leakage, but was still included in the calculation.

Daily mean leakage rates are plotted in figures 9 through 11 for the 2007 to 2009 irrigation seasons. Canal-leakage rates were not reported for periods of record not bracketed by discharge measurements. During such periods, the larger uncertainty in the computed daily mean discharge at each streamflow-gaging station potentially could mask canal leakage. 


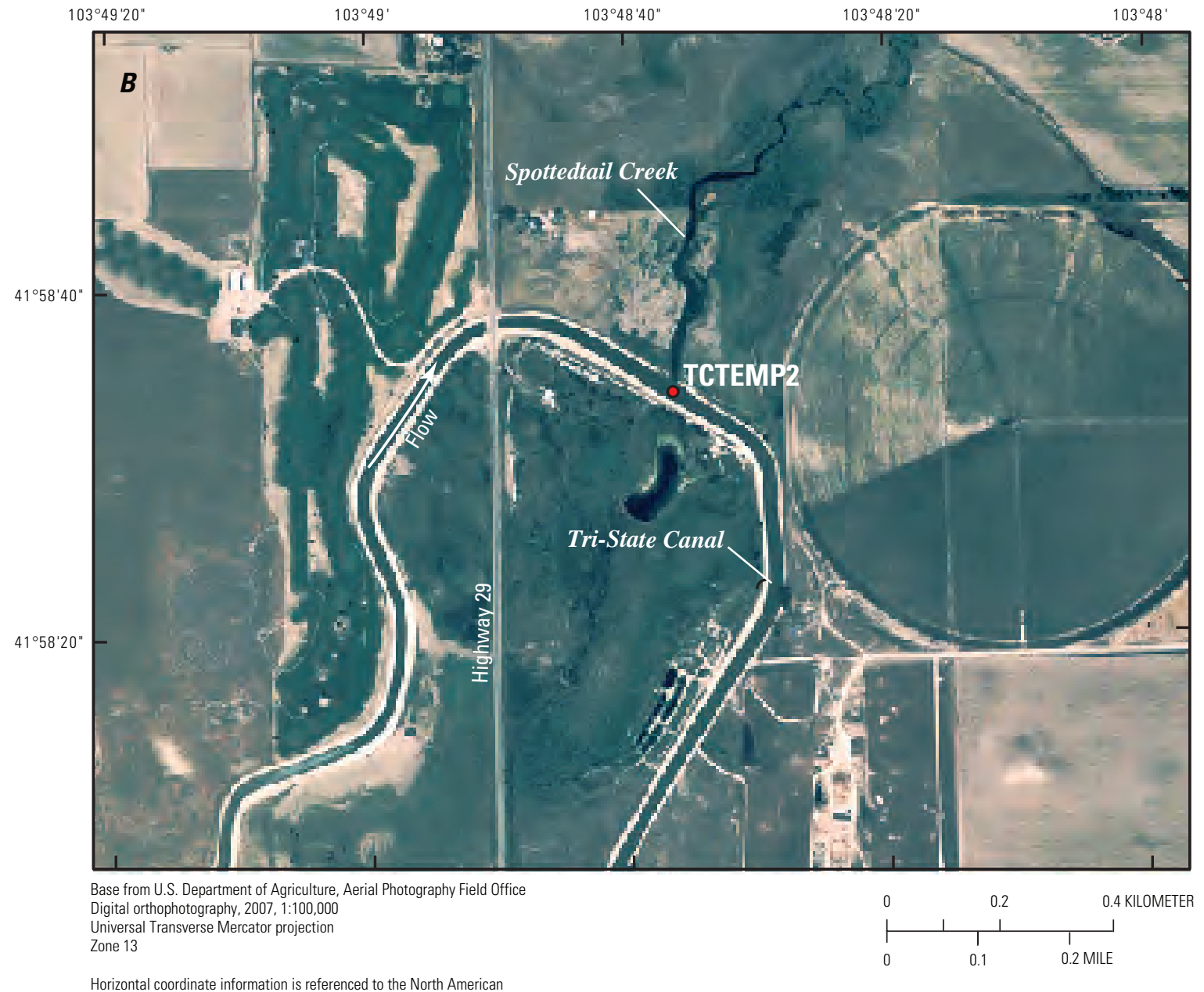

Horizontal coordinate information is referenced to the North American Datum of 1983 (NAD 83)

Figure 7.-Continued.

Leakage, thus, was calculated only for the period between the first and last ADCP discharge measurement each year.

Computed leakage rates (hereinafter referred to as leakage rates), given in units of meters per day, are defined as discharge loss per unit of bed area. Leakage rates varied from year to year and usually were dependent on local climatic conditions, and the timing and magnitude of the initial seasonal diversion into Tri-State Canal. Leakage rates ranged from $0.98 \mathrm{~m} / \mathrm{d}$ on June 22, 2007, to about 0 m/d during July 2009 . Generally speaking, drier local conditions resulted in higher leakage rates. Of the three years studied (2007-09), 2007 was the driest. Only $23.8 \mathrm{~cm}$ of precipitation was recorded the entire year at the Scottsbluff Airport (fig. 12) (National Oceanic and Atmospheric Administration, 2010). Of the total annual precipitation, $9.8 \mathrm{~cm}$ was recorded during the irrigation season from May through September 2007. Climatic conditions also are reflected in the pre-diversion season (October to April) discharge of the North Platte River (fig. 12). The discharge of the North Platte River during these months mainly is base flow from groundwater discharge. During the diversion season, reservoir releases to satisfy surface-water irrigation demands increase the river's discharge, masking base flow. North Platte River discharge for April and May 2007 (0.36 and $0.077 \mathrm{~m}^{3} / \mathrm{s}$, respectively) were the lowest monthly mean discharges recorded during the study period.

Water-supply conditions were so severe in 2007 that no hay run took place, and diversions into Tri-State Canal were delayed until late June. Hay runs occurred in 2008 and 2009; however, they were not included in mass-balance computation of leakage rates because the stage was too low for ADVMs to 


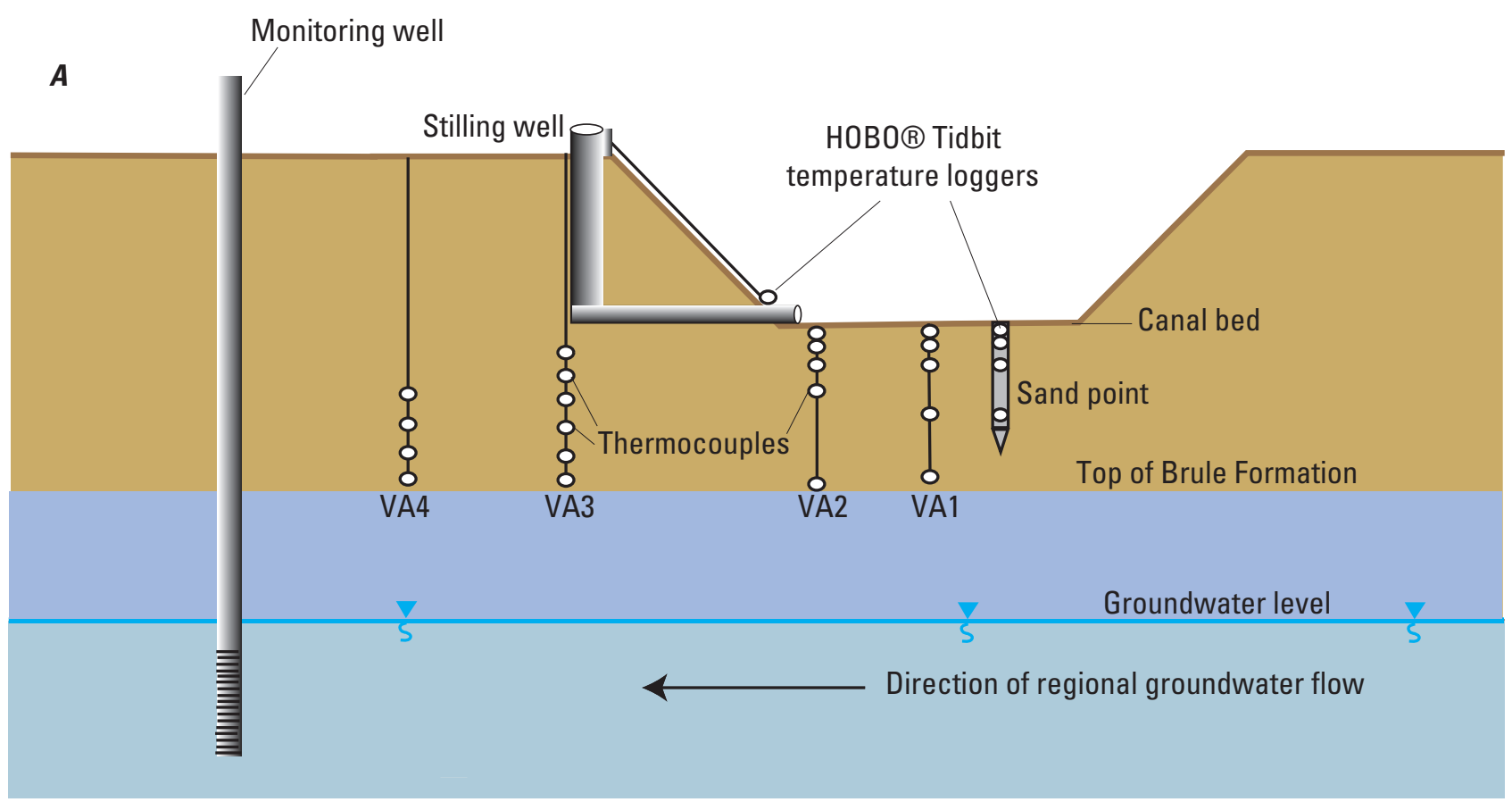

Not to scale

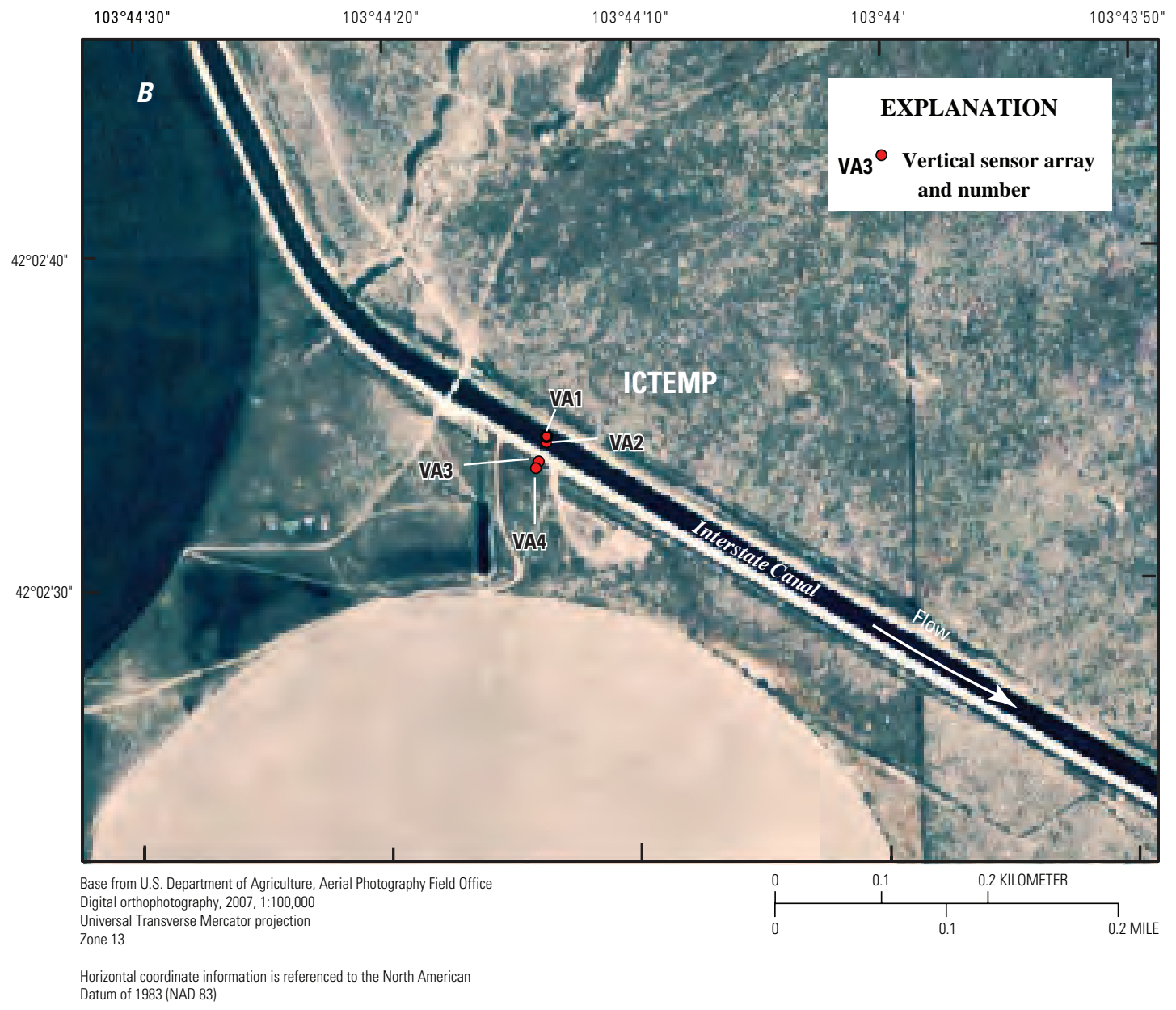

Figure 8. Generalized diagram (A) and map (B) of monitoring installation design used at site ICTEMP, Interstate Canal near University Lake, Nebr. 


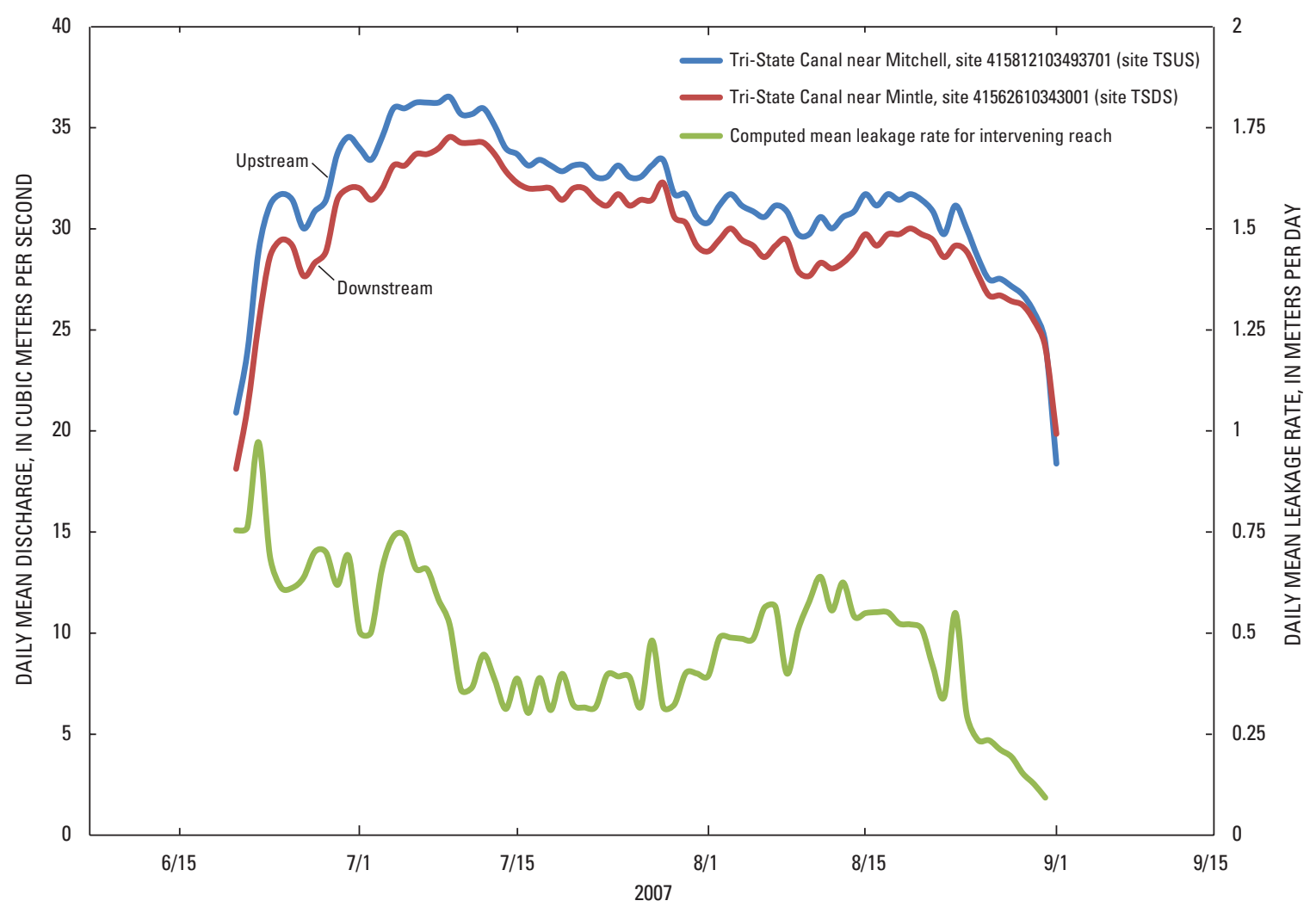

Figure 9. Daily mean upstream discharge, downstream discharge, and bed leakage rate, Tri-State Canal, late June to September, 2007.

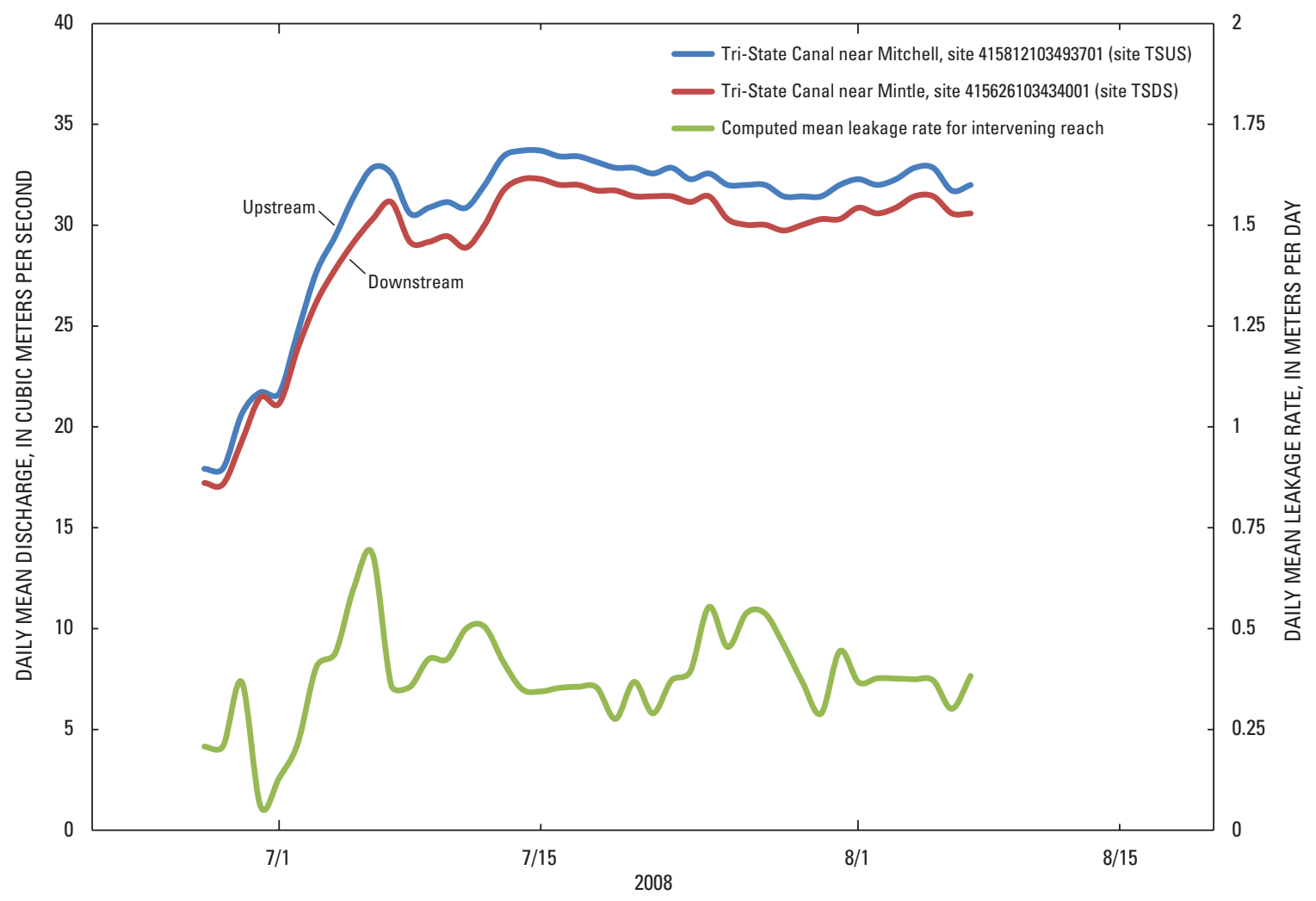

Figure 10. Daily mean upstream discharge, downstream discharge, and bed leakage rate, Tri-State Canal, late June to early August, 2008. 


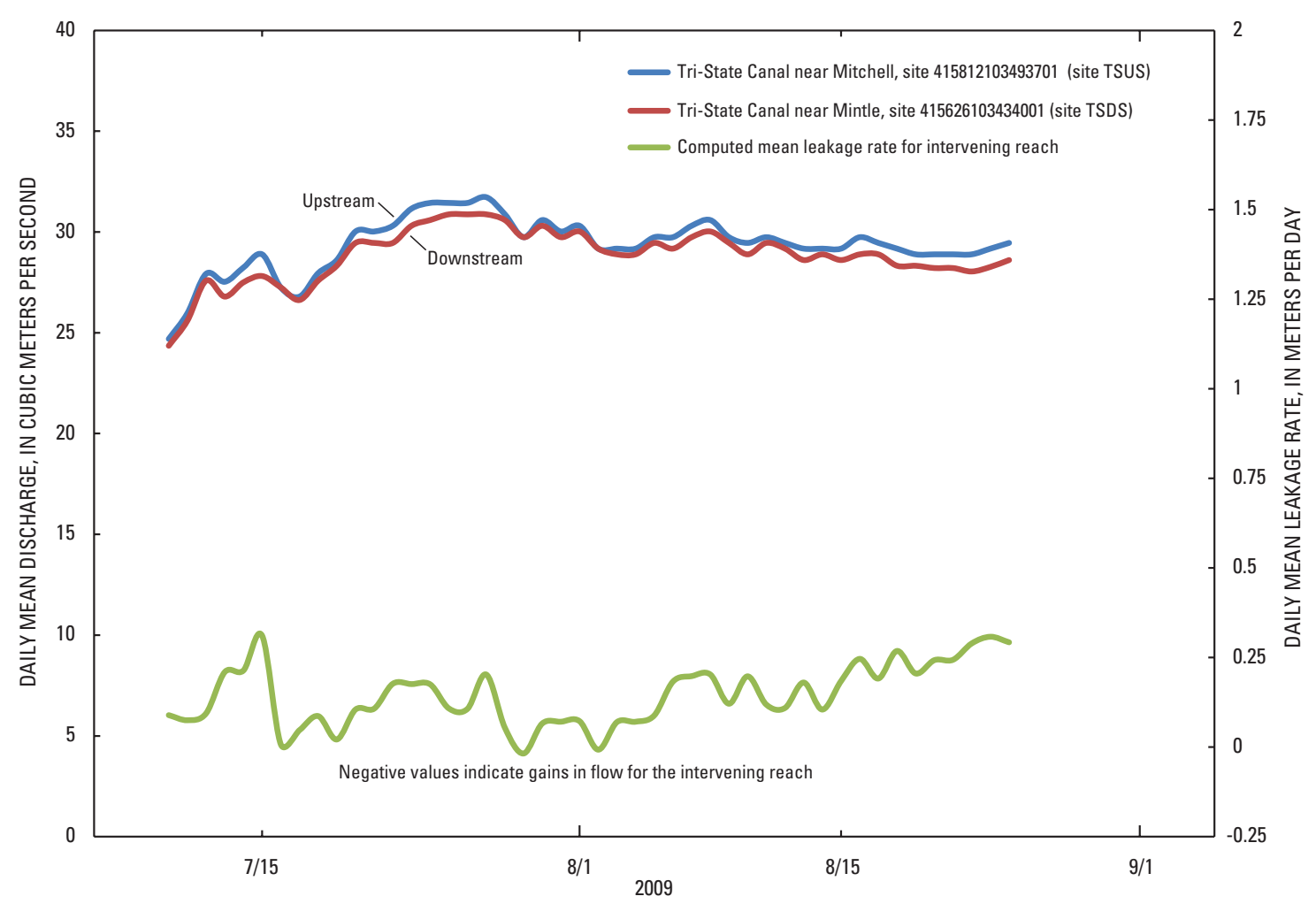

Figure 11. Daily mean upstream discharge, downstream discharge, and bed leakage rate, Tri-State Canal, early July to late August, 2009.

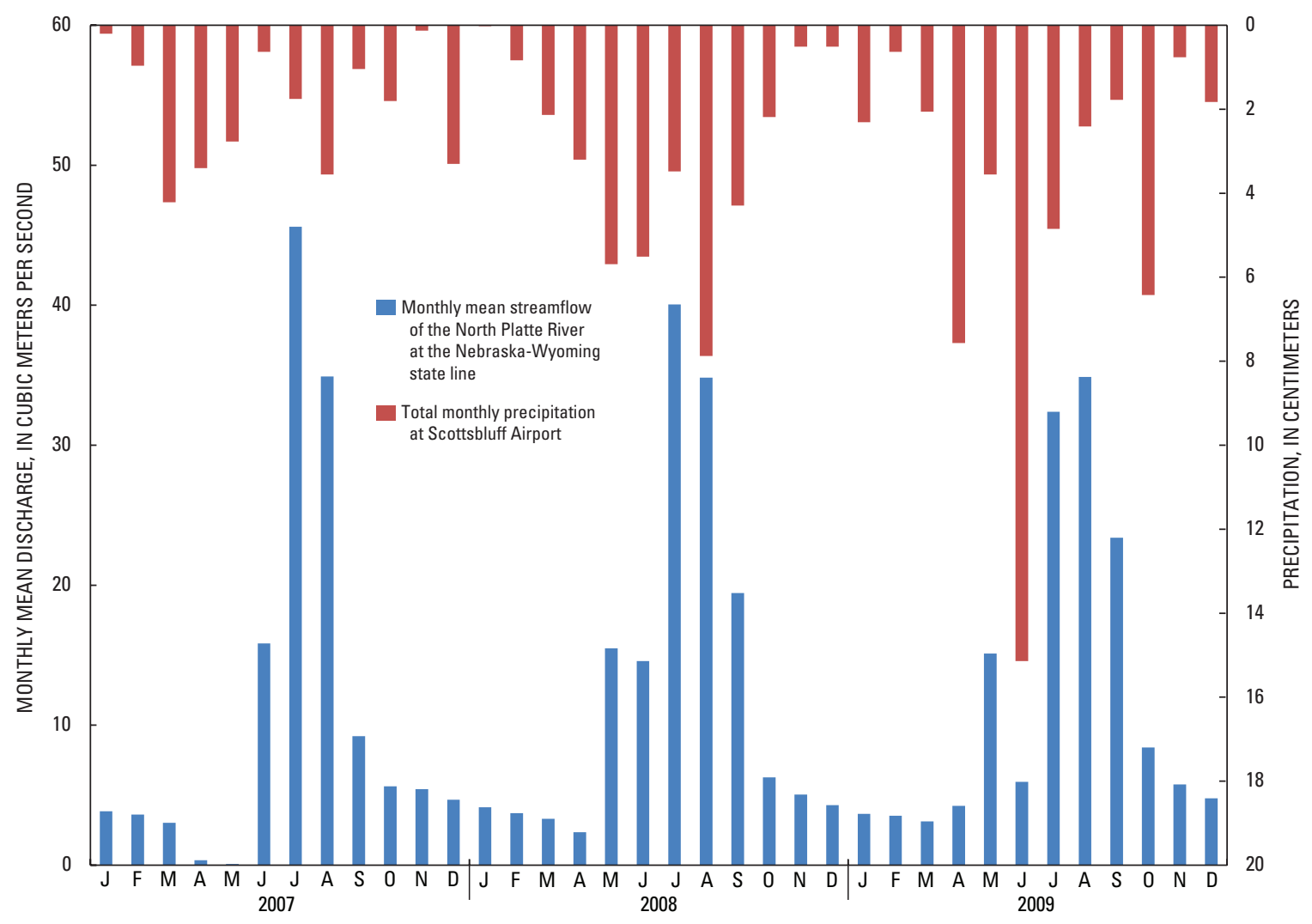

Figure 12. Monthly mean streamflow of North Platte River at the Nebraska-Wyoming state line (streamflow-gaging station 06674500) and total monthly precipitation measured at Scottsbluff Airport, January 2007 through December 2009. 
collect accurate velocity and stage data. Each year, calculated leakage rates were greatest when flow was first diverted into the canal system. Because the first diversions into Tri-State Canal in 2008 and 2009 were hay runs from which discharge was not measured, the calculated leakage rates were smaller than those in 2007. Discharge within part of the study reach of Tri-State Canal was greater in 2009 after the hay run and before the primary irrigation season than in 2007 or 2008 because of captured flow from Akers Draw and Spottedtail Creek, and to deliver water to Northport Canal (not shown on map). This sustained early wetting of the canal was a potential cause of the lower canal-leakage rates recorded during the early part of the irrigation season in 2009 as compared to 2007 and 2008.

\section{Interstate Canal Leakage Rates}

Daily mean computed discharges from ADVM ratings for the ISUS and ISDS streamflow-gaging stations are presented in figures 13 through 15 for a selected period of each year. The minimum computed discharge from Interstate Canal was $9.97 \mathrm{~m}^{3} / \mathrm{s}\left(352 \mathrm{ft}^{3} / \mathrm{s}\right)$ reported at the ISDS streamflow-gaging station on May 16, 2009 (not shown), and the maximum discharge was $26.8 \mathrm{~m}^{3} / \mathrm{s}\left(945 \mathrm{ft}^{3} / \mathrm{s}\right)$ reported at the ISUS streamflow-gaging station on July 27, 2007. In general, higher discharges occurred during the 2007 irrigation season in response to drier conditions and greater demands for irrigation water. Reported daily mean diversions to laterals within the study reach on Interstate Canal ranged from 0.57 to $6.5 \mathrm{~m}^{3} / \mathrm{s}$ (20 to $230 \mathrm{ft}^{3} / \mathrm{s}$ ). The larger diversions to laterals [typically 2.8 to $5.7 \mathrm{~m}^{3} / \mathrm{s}$ (100 to $200 \mathrm{ft}^{3} / \mathrm{s}$ )] were reported during the primary irrigation season from mid-July to early August when water demands were highest.

Computed leakage for the 2007-09 irrigation seasons is plotted in figures 13 through 15. Just as for Tri-State Canal, leakage was calculated only for the period between the first and last ADCP discharge measurement each year. Although the index discharge was within five percent of discharge measurements, the recorded 2007 irrigation-season flows indicated there were gains in discharge within the study reach of as much as $0.27 \mathrm{~m}^{3} / \mathrm{s}\left(9.4 \mathrm{ft}^{3} / \mathrm{s}\right)$. This is unlikely because the only inflow is a drainage culvert that would only flow during wetweather conditions. Apparent gains in flow may be the result of relative proximity to Lake Alice where high water levels may cause backwater conditions and alter the index velocitydischarge relation for part of an irrigation season, and thus, introduce error in the mass-balance calculations. Excluding the leakage calculations from early May 2007, the leakage rates ranged from 0.08 to $0.7 \mathrm{~m} / \mathrm{d}$. Less variability in leakage from

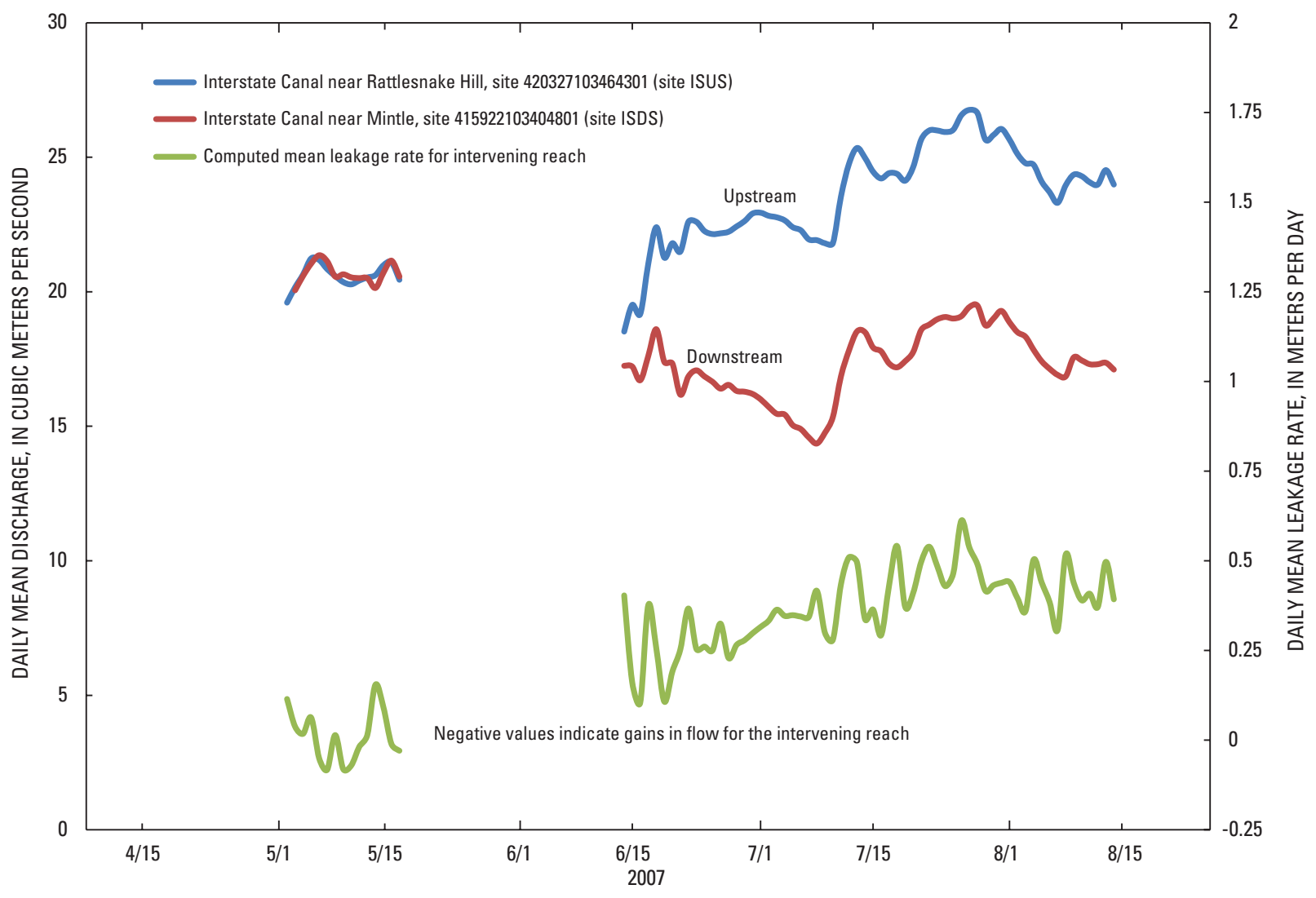

Figure 13. Daily mean upstream discharge, downstream discharge, and bed leakage rate, Interstate Canal, May to mid-August, 2007. 


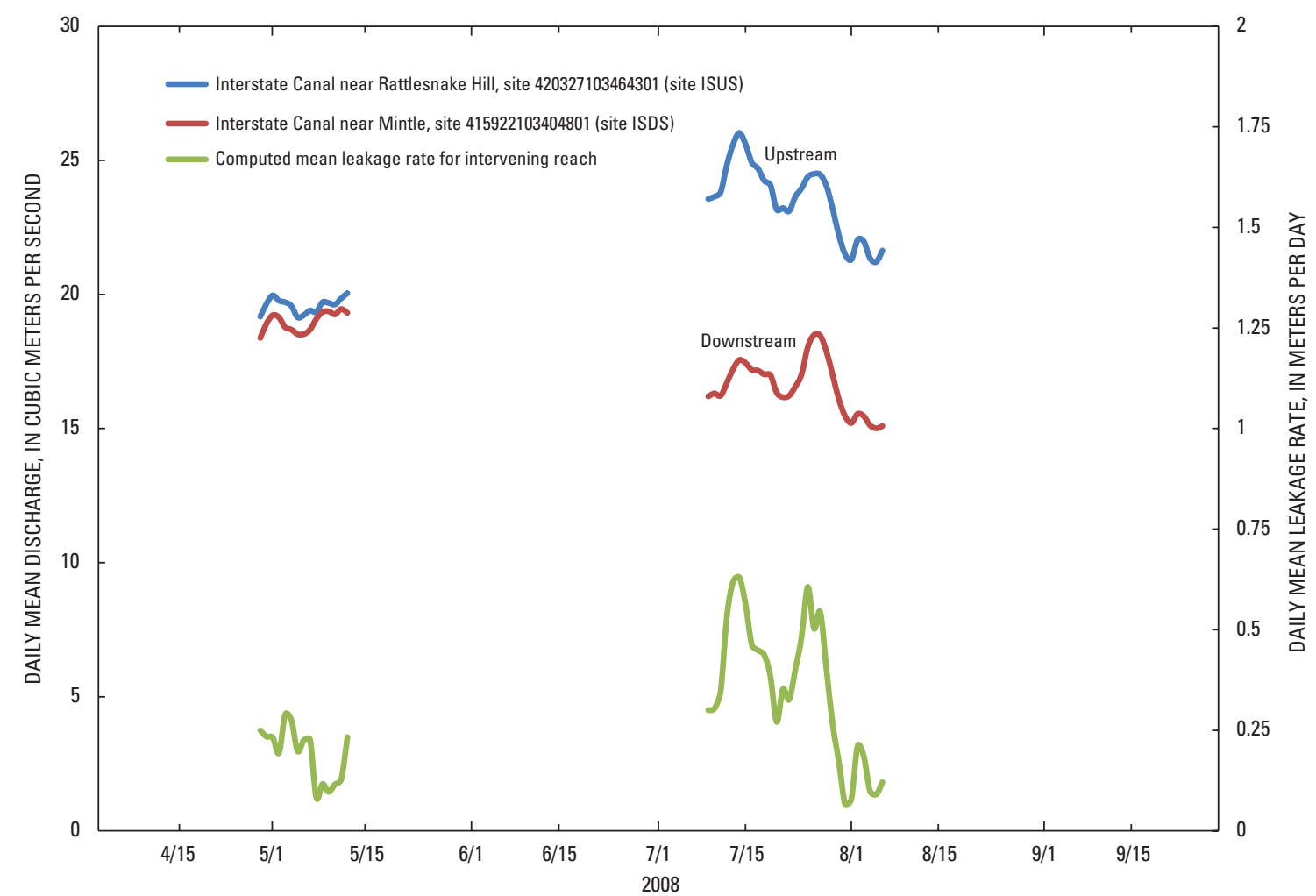

Figure 14. Daily mean upstream discharge, downstream discharge, and bed leakage rate, Interstate Canal, late April to early August, 2008.

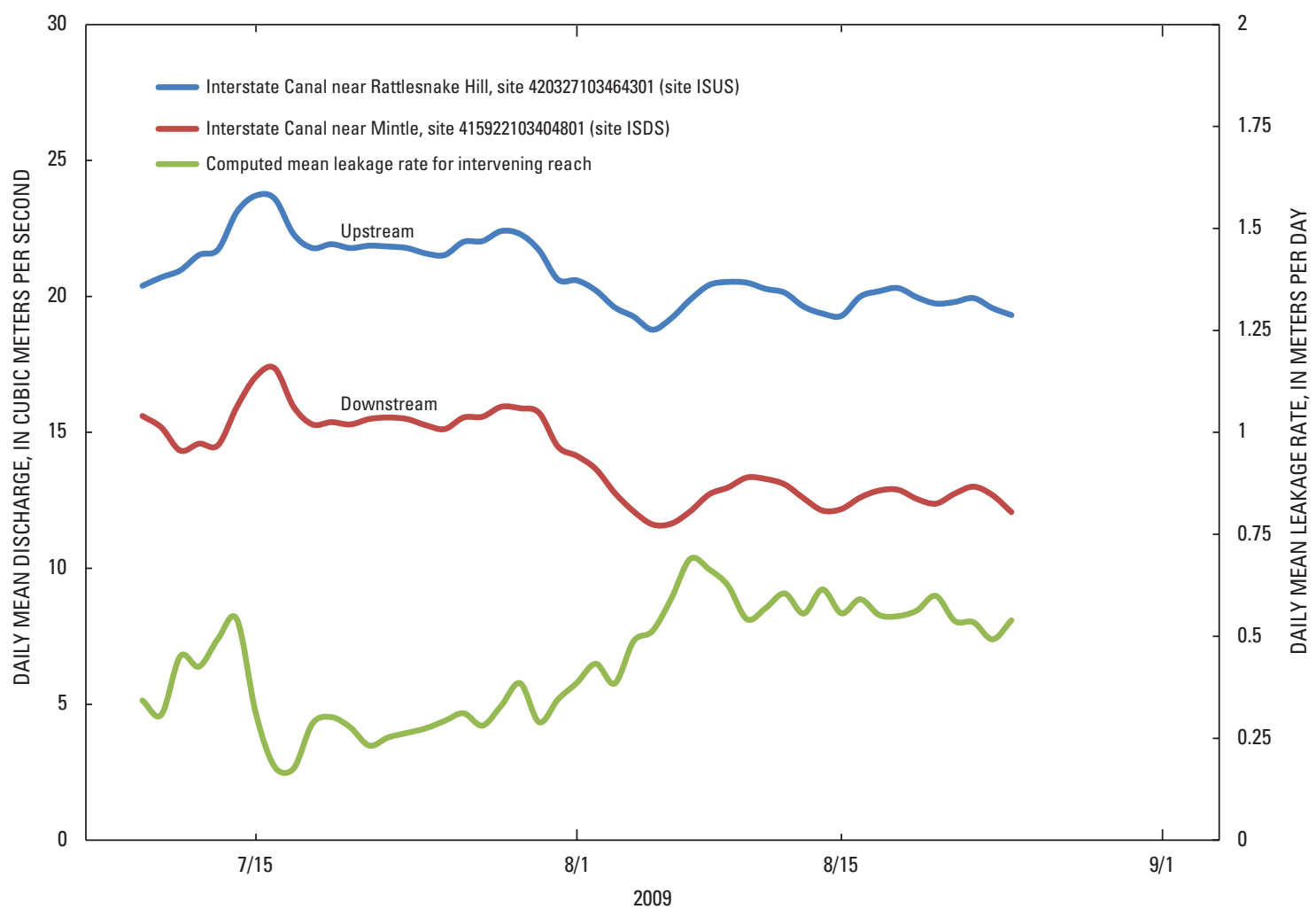

Figure 15. Daily mean upstream discharge, downstream discharge, and bed leakage rate, Interstate Canal, early July to late August, 2009. 
year to year indicates that climatic conditions may have less of an effect for Interstate Canal compared to Tri-State Canal. This may be because Interstate Canal was cut into the northern edge of the North Platte alluvial valley and consequently the canal bed is well above the local groundwater table resulting in a constant $(-1 \mathrm{~m} / \mathrm{m})$ hydraulic gradient. Interstate Canal also does not receive any captured flow that can vary substantially year to year.

\section{Heat-Based Hydraulic Conductivity Estimates}

\section{Tri-State Canal near Mitchell, Nebr.}

Seasonal flow patterns in Tri-State Canal affected the temperature patterns of the shallow sediment beneath the canal. Each year before the initial diversion into Tri-State Canal, diurnal variations in sediment temperature in shallow thermocouples and thermistors occurred because of daytime heating and nighttime cooling. A disruption in the diurnal temperature cycle in the shallow thermocouples or thermistors signaled the arrival of canal water. This disruption in the temperature cycle was recorded in deeper thermocouples at only slightly later times compared to shallow thermocouples because of the infiltration of water to these depths (fig. 16). The amplitude of the diurnal temperature cycle was dampened at depth as heat was transferred from the canal water to the surrounding sediments.

Measured groundwater level rises typically occurred within 24 hours after flow arrived at a temperature monitoring site at the start of an irrigation season (fig. 17). Groundwater levels rose continuously when canal flows approached maximum capacity until diversions were decreased in September. Small diurnal water temperature variations $\left(1.0\right.$ to $\left.1.5^{\circ} \mathrm{C}\right)$ were measured when canal flow was near maximum capacity (fig. 18). The temperature and stage sensors were above the surface of the water when the canal stage was below $0.76 \mathrm{~m}$. This low-stage condition of Tri-State Canal was restricted to periods when the canal was delivering water only to Northport Canal (not shown on map) or a natural flow period following the primary irrigation season when canal flow was sustained by captured flow. Larger diurnal variations in temperatures of the canal water and shallow bed sediment were measured during lower discharge periods.

The vertical hydraulic conductivity of the poorly sorted sand and gravel beneath site TCTEMP1 is estimated using a calibrated VS2DH model. Based on the trial-and-error approach, the best-fit vertical hydraulic conductivity for the entire site TCTEMP1 model domain was $1.1 \mathrm{~m} / \mathrm{d}$. This value

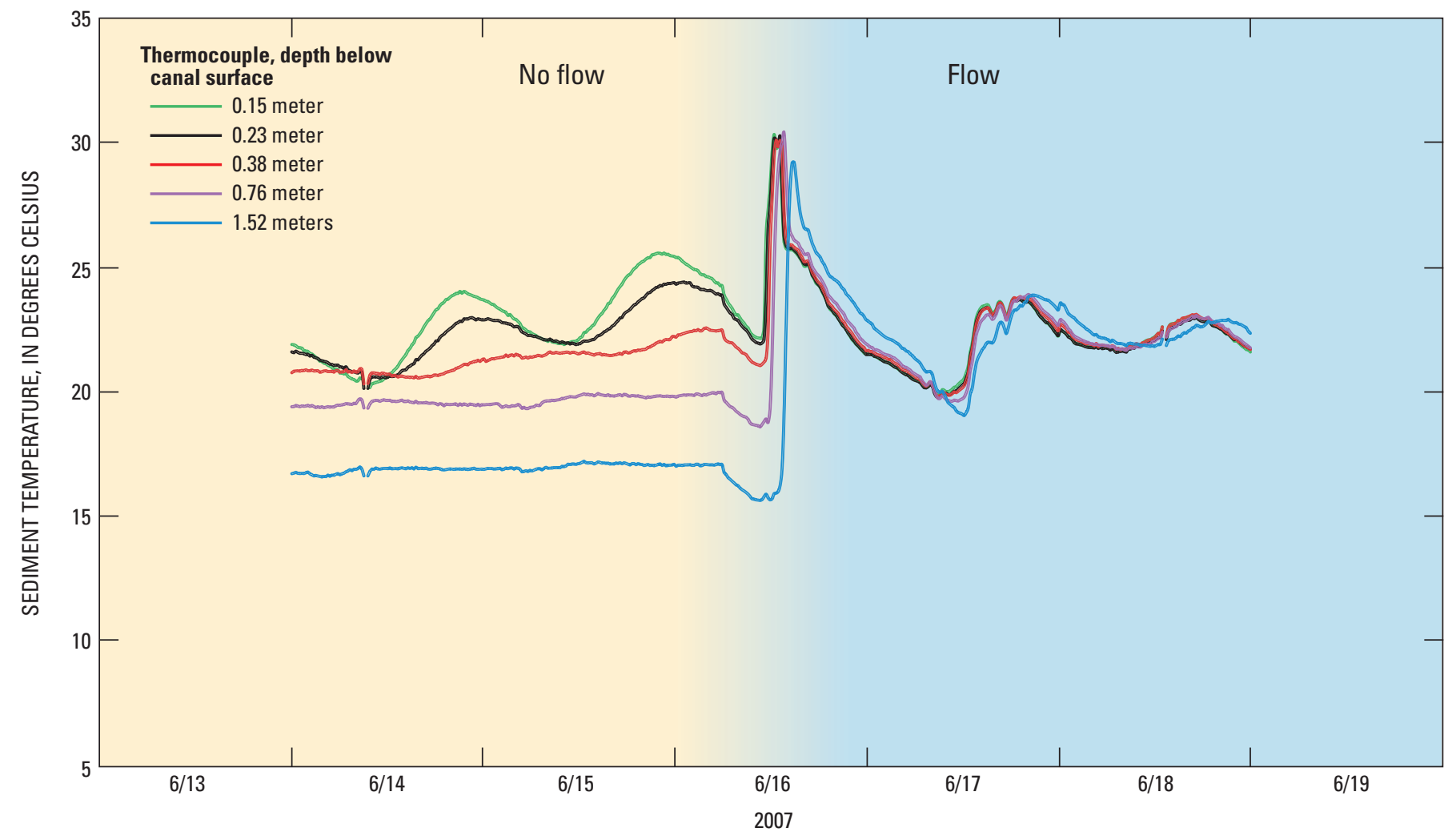

Figure 16. Thermograph of sediment beneath Tri-State Canal from vertical sensor array 4 during initiation of seasonal flow, June 2007. 


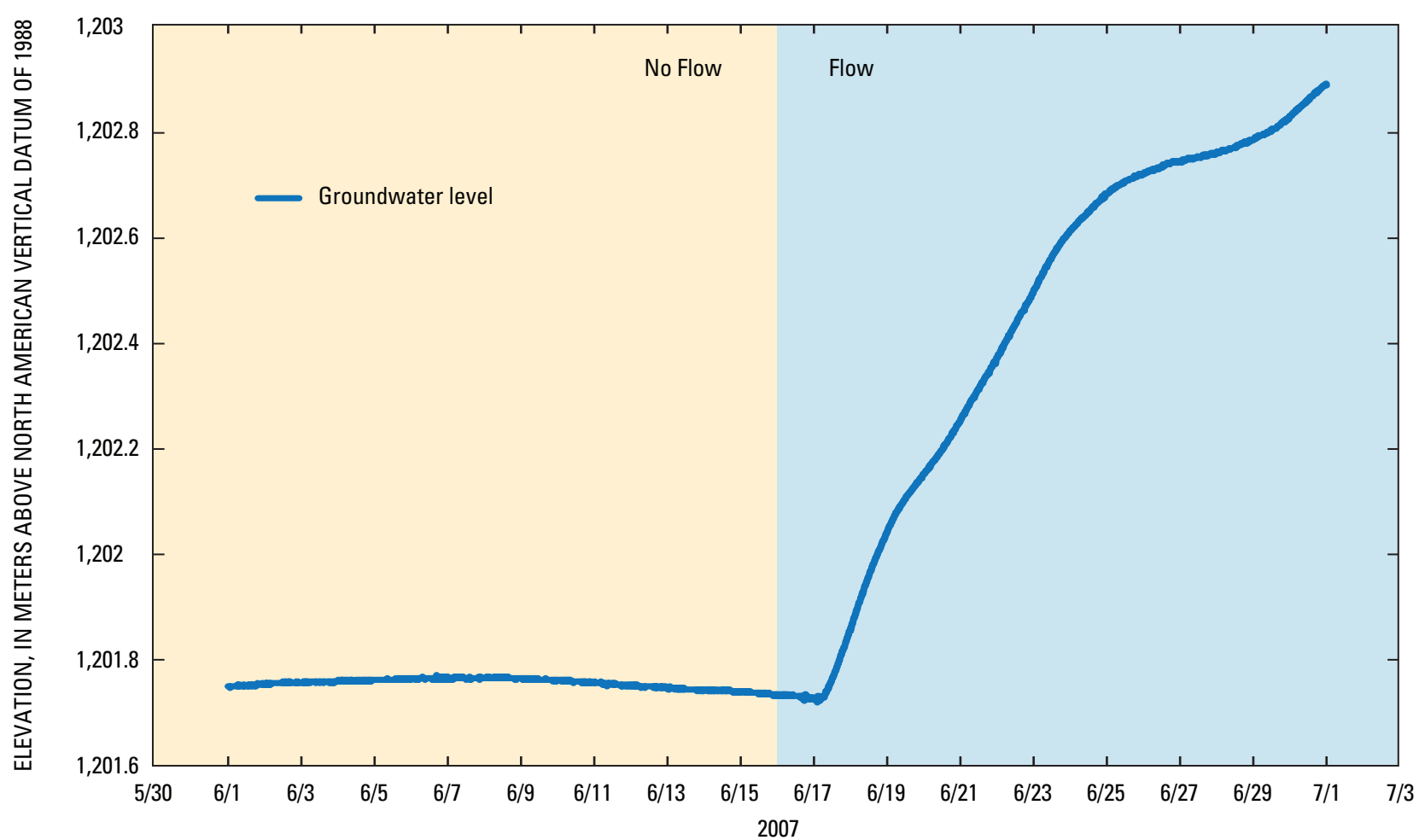

Figure 17. Groundwater level recorded near Tri-State Canal near Mitchell, Nebr., June 2007.

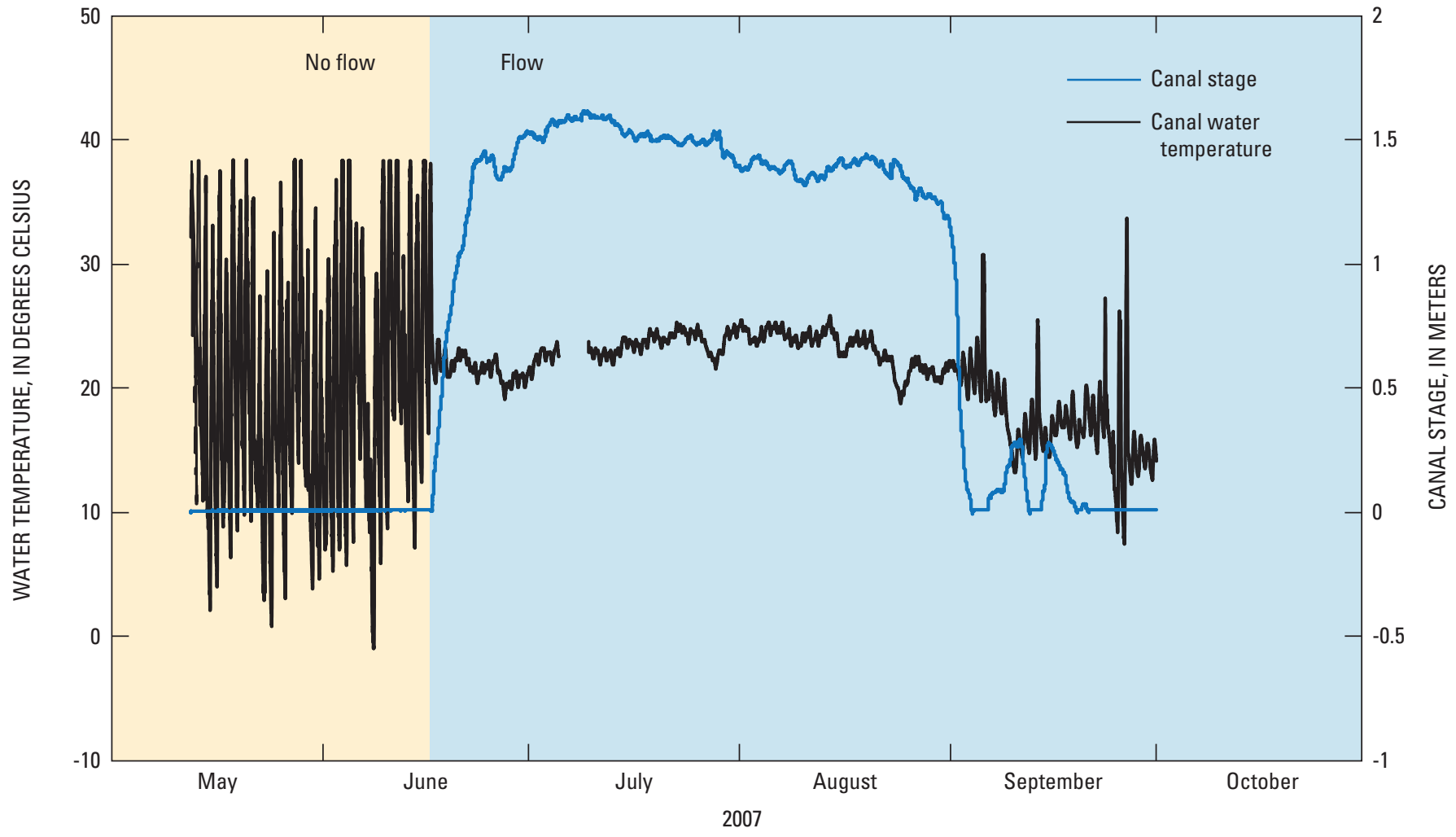

Figure 18. Water temperature and stage in Tri-State Canal near Mitchell, Nebr., May through September, 2007. 
falls within the range of hydraulic conductivities for sand and gravel given by Domenico and Schwartz (1998). Example plots of measured and simulated sediment temperatures are shown in figures 19 through 21. Precise estimation of the vertical hydraulic conductivity was difficult because of the relatively small diurnal variation in canal water temperature. Model fits were best for temperature sensors shallower than $0.76 \mathrm{~m}$ when flow was vertical. Below a depth of $0.76 \mathrm{~m}$, flow in canal-bed sediment most likely became multidimensional as indicated by dampened diurnal cycles in measured data relative to simulated. Hoffman and others (2007) reported a similar interpretation when modeling channel infiltration with a one-dimensional VS2DH model.

The calibrated model was able to fit simulated to measured subsurface temperatures collected in 2007 and 2009 (figs. 19 and 20); however, the simulations for May and June 2008 did not produce satisfactory results (not shown). Model simulations were not attempted for the period after July 7 because the sensor recording canal water temperature was disturbed and ceased collecting data. The sediment diurnal temperature cycles measured for thermistors and thermocouple arrays were much more dampened compared to simulated temperatures. The dampened temperature cycles indicate reduced leakage rates through canal-bed sediments. Because it is unlikely that the vertical hydraulic conductivity of the underlying canal-bed sediments had changed, a reduction in leakage may have been caused by a lower hydraulic-conductivity layer that was deposited over sensor arrays. During site visits occurring between diversion periods, evidence of localized scouring and deposition of sediment on the canal bed was observed. Deposition of sediment over sensor arrays likely would dampen measured diurnal sediment temperature cycles and potentially could reduce canal leakage. Sediment deposition may be localized such that it may not affect the leakage rates of an entire reach.

Additional model simulations included a hypothetical sediment layer having a lower vertical hydraulic conductivity layer and positioned on top of the calibrated model domain,

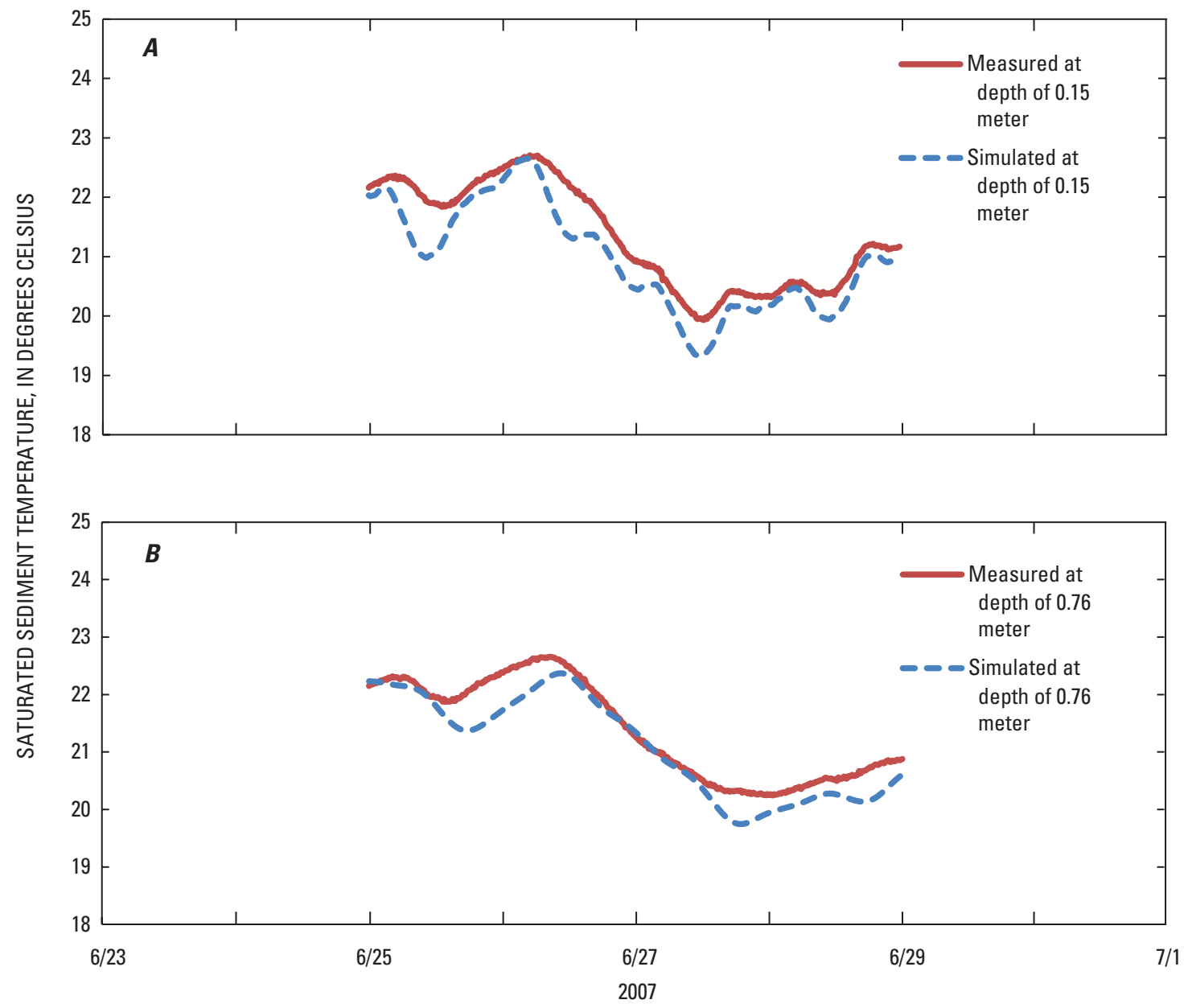

Figure 19. Measured and simulated thermographs for saturated sediment at (A) $0.15 \mathrm{~m}$ and (B) 0.76 meter beneath Tri-State Canal near Mitchell, Nebr., 2007. 


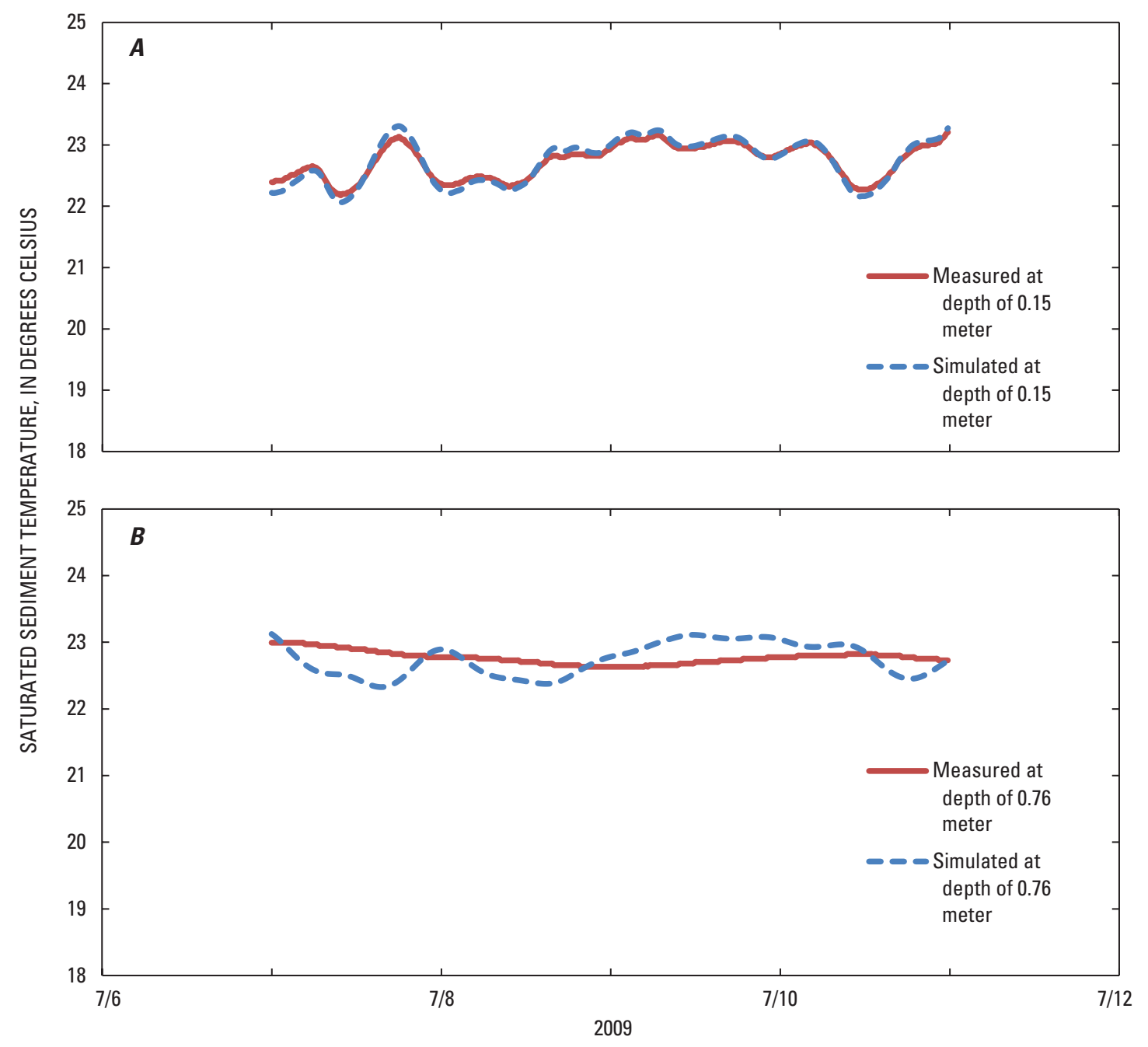

Figure 20. Measured and simulated thermographs for saturated sediment at (A) 0.15 meter and (B) 0.76 meter beneath Tri-State Canal near Mitchell, Nebr., 2009.

though no field data collected support this hypothesis. The hypothetical layer was a $10-\mathrm{cm}$ layer of silt loam with a vertical hydraulic conductivity of $0.17 \mathrm{~m} / \mathrm{d}$ above the sensor arrays. The amplitude and timing of simulated temperature peaks matched measured data for the 0.15 - and 0.23 -m sensors; however, measured diurnal sediment temperature cycles below these depths are dampened compared to simulated temperatures (fig. 21). This may be attributed to the lower conductivity layer reducing leakage rates such that the diurnal temperature cycle is masked in the canal-bed sediments deeper than $0.23 \mathrm{~m}$ resulting in poor model fits.

\section{Tri-State Canal at Spottedtail Creek, Nebr.}

The seasonal flow patterns of Tri-State Canal affected the measured temperature of the canal water and the shallow groundwater at site TCTEMP2. Lower flows at site TCTEMP2 coincided with larger diurnal variability in canal water temperatures (fig. 22). Measured groundwater temperature did not display diurnal variation in water temperature, but rather seasonal warming and cooling in response to changes in canal water temperature. Measured pressure head beneath Tri-State Canal closely resembled measured canal stage (fig. 23).

The hydraulic gradient for the period of data collection ranged from -0.14 to $-0.07 \mathrm{~m} / \mathrm{m}$ indicating continued leakage to the groundwater system (fig. 24A). The hydraulic gradient increased during the hay run and peaked in June before the primary irrigation season. This increase in hydraulic gradient is most likely a result of the groundwater level rising in response to increases in local precipitation and base flow from Spottedtail Creek (fig. 24B). Several peaks in canal stage were the result of sharp increases in discharge in Spottedtail Creek during storm runoff. Throughout the primary irrigation season, canal stage and hydraulic gradient 


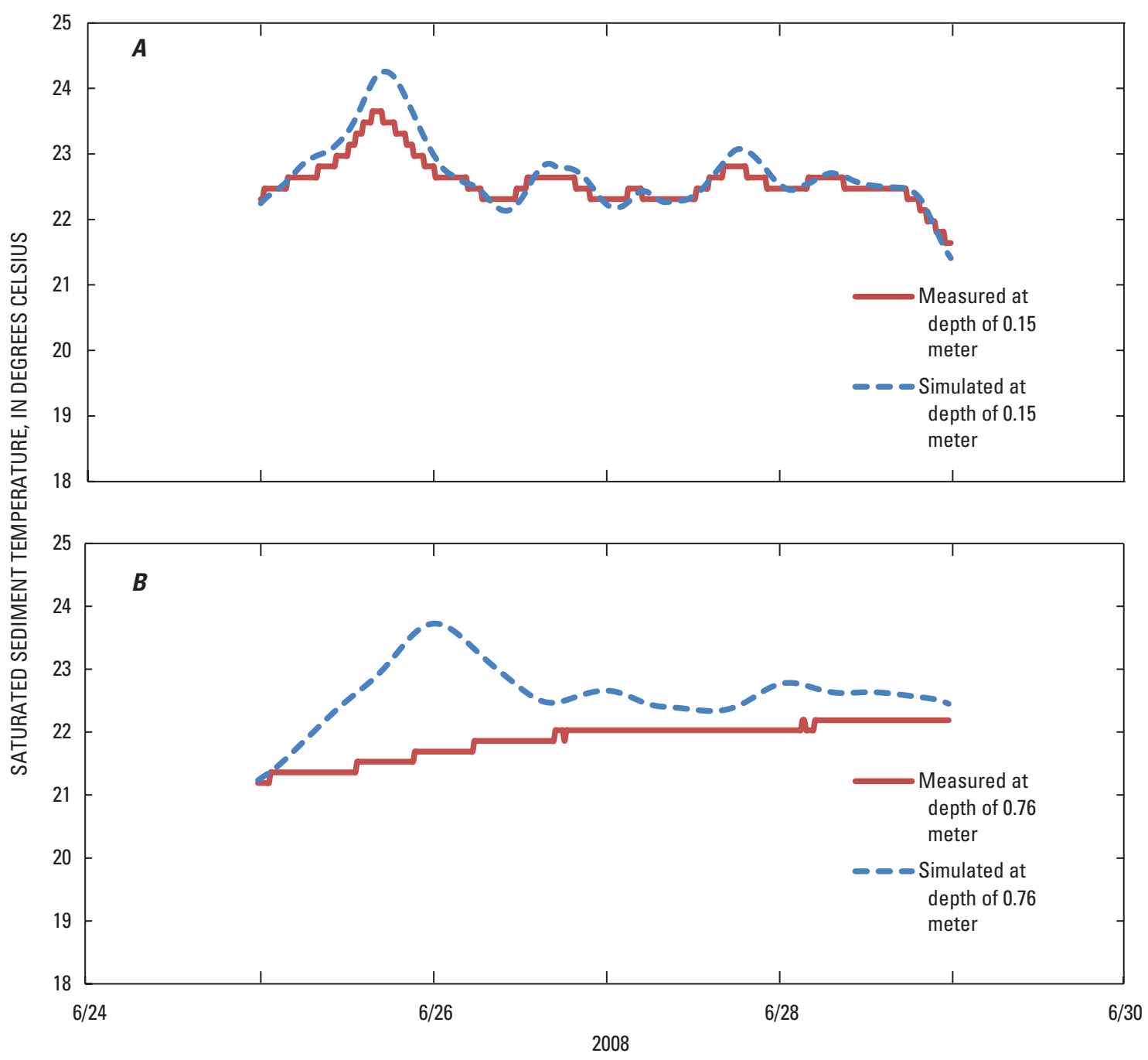

Figure 21. Measured and simulated thermographs for saturated sediment (including a hypothetical top layer of silt) at (A) 0.15 meter and (B) 0.76 meter beneath Tri-State Canal near Mitchell, Nebr., 2008.

were inversely related indicating that higher canal stages induced greater potential for losses to the groundwater system.

The simulation period for VS2DH-based estimation of vertical hydraulic conductivities started when canal stage was steady and near its maximum during the primary irrigation season, which are conditions when leakage primarily would be vertical and the effects of multidimensional flow would be minimized. Description of the sediment core indicated a $0.25-\mathrm{m}$ layer of medium sand overlying a $0.66-\mathrm{m}$ layer of fine sand (appendix 1). Sediment layer thicknesses were adjusted from the thicknesses reported in appendix 1 because of incomplete sample recovery. The best-fit modeled vertical hydraulic conductivity estimated for this flow condition was $17 \mathrm{~m} / \mathrm{d}$ for the medium sand layer and $1.1 \mathrm{~m} / \mathrm{d}$ for the fine sand layer (mean of $1.5 \mathrm{~m} / \mathrm{d}$ ). An example simulated thermograph produced using the previously stated vertical hydraulic conductivities plotted with measured thermographs is shown in figure 25. Both hydraulic conductivities agree well with published ranges for fine and medium sand (Domenico and Schwartz, 1998).

\section{Interstate Canal near University Lake, Nebr.}

Diversion into Interstate Canal at the start of 2008 irrigation also resulted in sharp rises in groundwater levels recorded in the observation well (fig. 26). Changes in canal discharge result in near instantaneous responses in groundwater level. The high degree of synchrony suggests that fractures in the Brule Formation are present. Measured groundwater temperatures ranged from about 17.5 to $18.2^{\circ} \mathrm{C}$. A strong seasonal variation is clear within the irrigation season. Canal water temperature during the irrigation season varied from 4 to $25^{\circ} \mathrm{C}$ and displayed a diurnal variability of $2{ }^{\circ} \mathrm{C}$ in the period of record (fig. 27). 


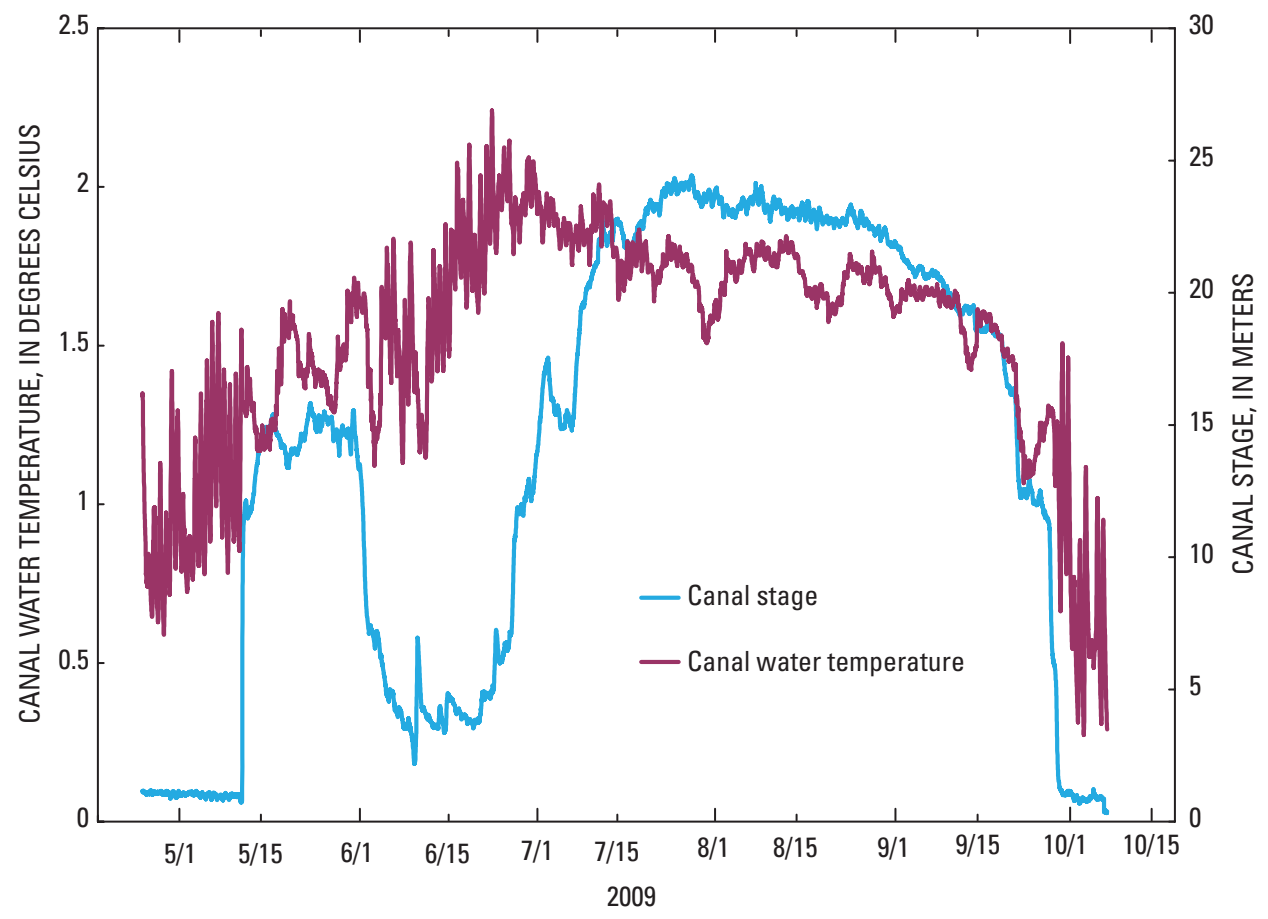

Figure 22. Water temperature and stage in Tri-State Canal at Spottedtail Creek, Nebr., May to October, 2009.

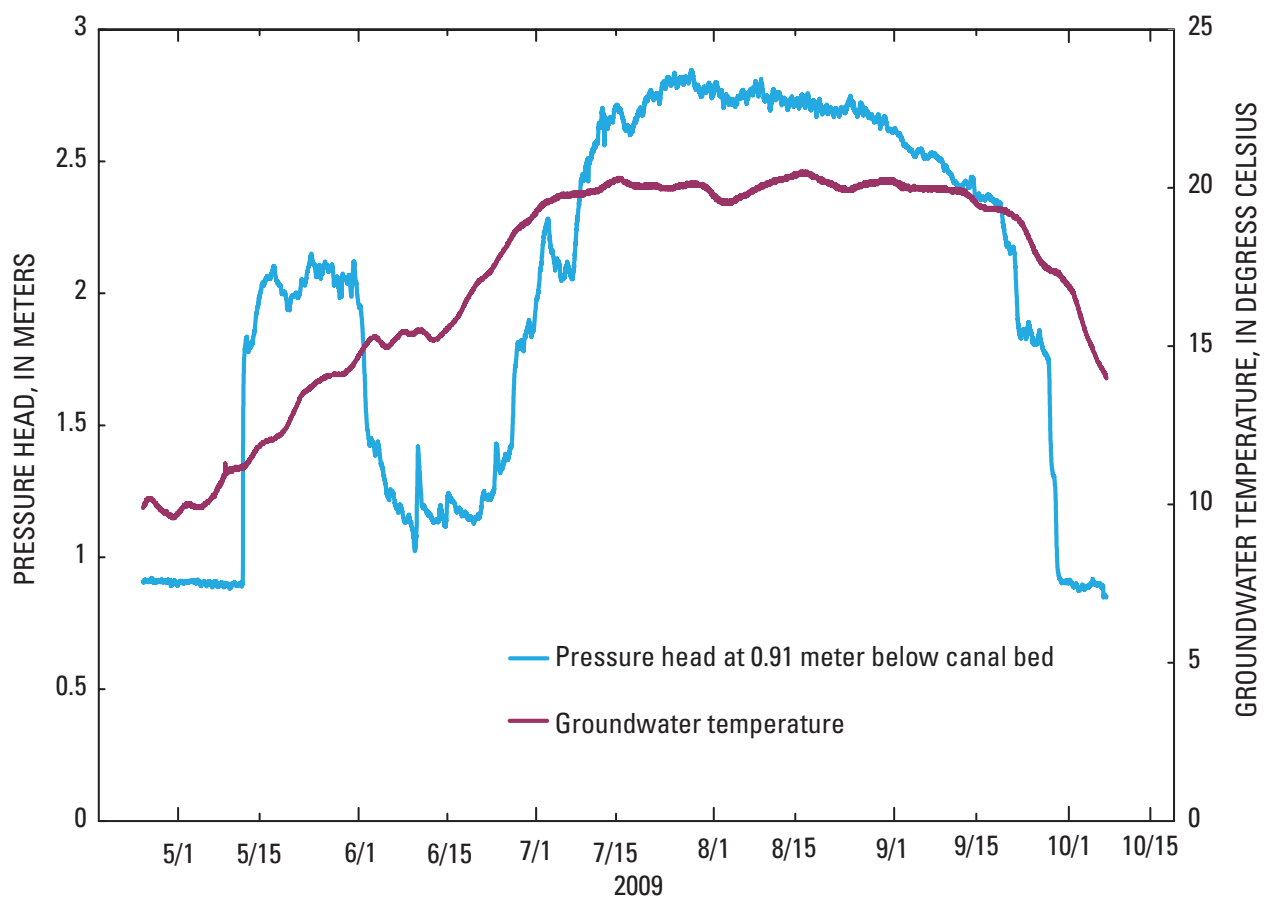

Figure 23. Pressure head and temperature recorded 0.91 meter below Tri-State Canal at Spottedtail Creek, Nebraska, May to October, 2009. 

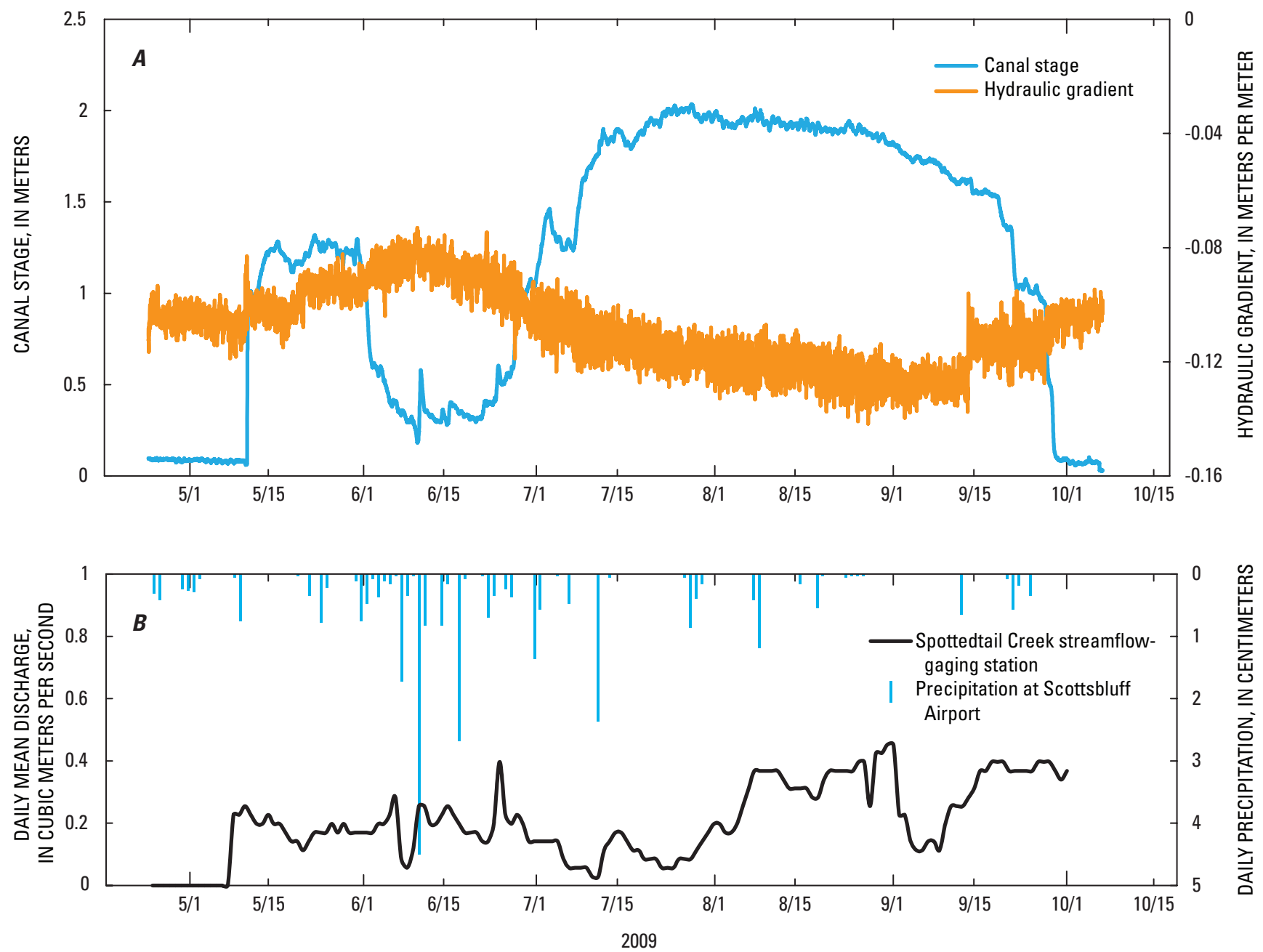

Figure 24. Canal stage and hydraulic gradient measured beneath Tri-State Canal at Spottedtail Creek (A), discharge reported at Spottedtail Creek streamflow-gaging station, and precipitation recorded at Scottsbluff Airport (B), March to October 2009. (Sources of data: stream discharge from Bureau of Reclamation, 2009; precipitation data from National Oceanic and Atmospheric Administration, 2009.)

Recorded sediment temperatures, both from thermocouples and thermistors, displayed diurnal cycles that became dampened with depth. Sediment temperature data from the deeper thermocouples, installed in the weathered Brule Formation, mainly recorded only seasonal variations in sediment temperature (sensor array VA1, $4.5 \mathrm{~m}$ ), near that of the groundwater temperature of $18{ }^{\circ} \mathrm{C}$. The arrival of canal water during the hay run or primary irrigation season produced an abrupt change in the temperature pattern of sensors installed in the sediment beneath the canal (fig. 28). Sediment temperatures from sensor arrays VA3 and VA4 indicate nearly constant temperature in the weathered Brule Formation, varying less than $1^{\circ} \mathrm{C}$. Canal leakage at site ICTEMP may primarily be vertical because of the relatively low variability in recorded sediment temperature data from sensor arrays VA3 and VA4. Based on the relatively flat sediment temperature response and the change in groundwater levels, it is thought that groundwater movement through the shallow Brule Formation beneath
Interstate Canal would bypass the VA3 and VA4 sensor arrays. Temperature changes in sediment from advective heat transport, as seen for sensor array VA1 (4.5 m depth), would have caused an obvious departure from this seasonal heating and cooling temperature pattern (fig. 28).

The vertical hydraulic conductivities of the sediment layers were estimated using calibrated one-dimensional VS2DH models. After using a trial-and-error approach for calibration, the average vertical hydraulic conductivities were estimated at $17 \mathrm{~m} / \mathrm{d}$ for the medium sand unit, $2.1 \mathrm{~m} / \mathrm{d}$ for the fine sand unit, and $0.69 \mathrm{~m} / \mathrm{d}$ for the silt and weathered Brule Formation. The estimated hydraulic conductivities agree well with published ranges for medium and fine sand (Domenico and Schwartz, 1998) and weathered Brule Formation (Barrash and Morin, 1987). The simulated sediment temperatures were in closest agreement with measured temperatures at shallow thermocouples and thermistors where flow primarily was vertical (fig. 29). Below $0.76 \mathrm{~m}$, flow likely became multidimensional, 


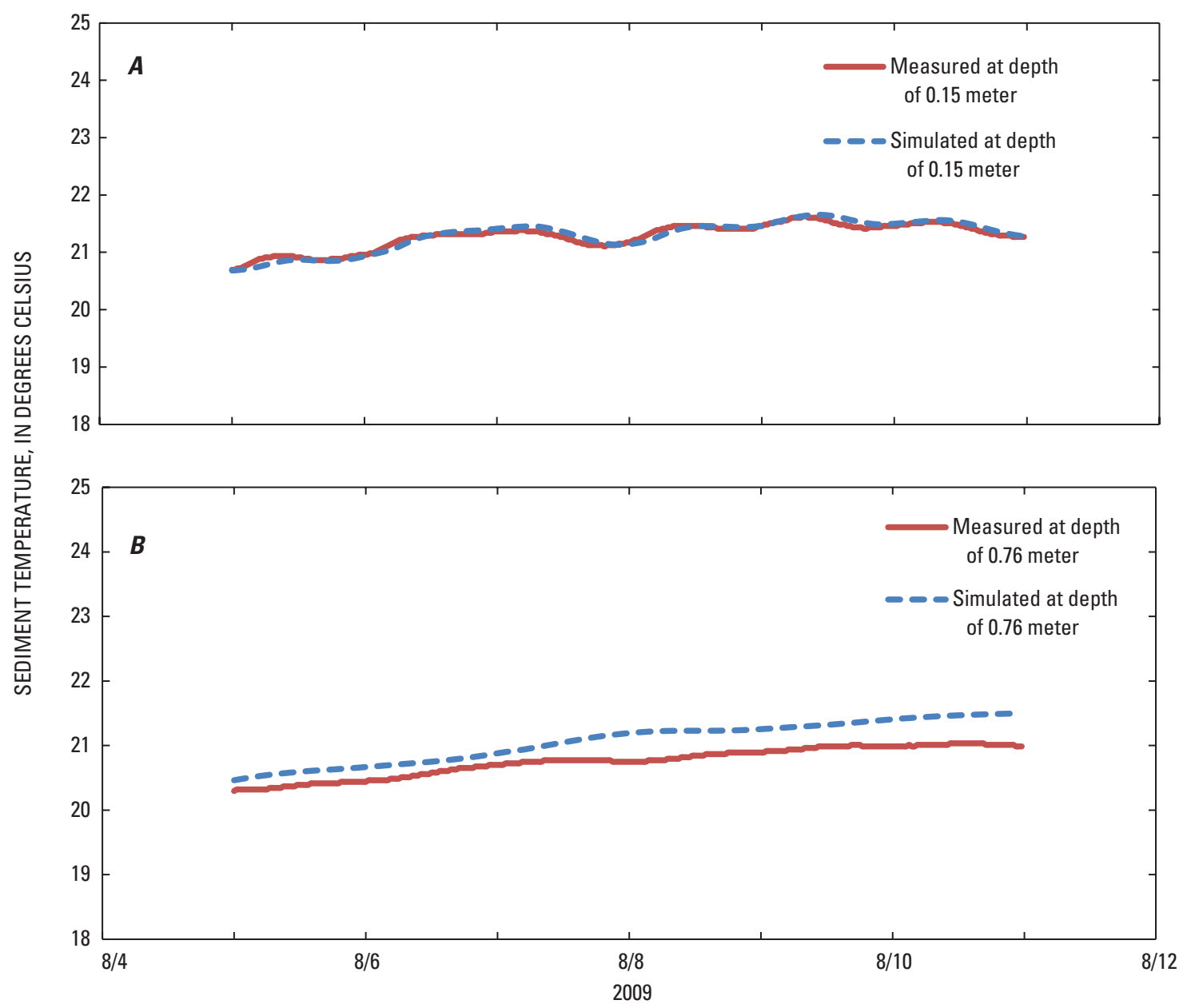

Figure 25. Example measured and simulated thermographs for saturated sediment at (A) $0.15 \mathrm{~m}$ and (B) 0.76 meter beneath Tri-State Canal at Spottedtail Creek, Nebr., 2009.

and recorded data indicated dampened diurnal temperature cycles.

\section{Leakage Rate Comparisons}

Reach-average leakage rates calculated using the massbalance approach along the high-leakage potential reach of Tri-State Canal varied from year to year and were generally dependent on local climatic conditions, and the timing and magnitude of the initial seasonal diversion into Tri-State Canal. Leakage rates ranged from $0.98 \mathrm{~m} / \mathrm{d}$ on June 22, 2007, to about to $0 \mathrm{~m} / \mathrm{d}$ in July 2009. Drier conditions usually resulted in higher leakage rates because of reduced flow from Spottedtail Creek, lower groundwater levels near Spottedtail Creek, and little unmeasured flow entering the reach.

Within the high-leakage potential reach the water table was well below the bed of the canal for most of the reach. Leakage rates calculated using the mass-balance approach can be compared to the heat-based vertical hydraulic conductivity estimates using Darcy's Law if the hydraulic gradient for the entire reach can be estimated. Assuming a hydraulic gradient of $1 \mathrm{~m} / \mathrm{m}$ at site TCTEMP1, the canal-leakage rate is $1.1 \mathrm{~m} / \mathrm{d}$. This assumption does not apply at site TCTEMP2, where the groundwater table was near the canal bed, and the hydraulic gradient was variable. Multiplying the calculated mean vertical hydraulic conductivity of $1.5 \mathrm{~m} / \mathrm{d}$ by the hydraulic gradient yielded leakage rates that ranged from 0.1 to $0.2 \mathrm{~m} / \mathrm{d}$. This indicates that a shallow water table at site TCTEMP2 near the mouth of Spottedtail Creek restricted canal leakage. Because hydraulic gradient was determined for one point, it is not appropriate to spatially extrapolate leakage-rate estimates to the entire study reach. Reach-average leakage rates calculated using the mass-balance approach indicates that climatic conditions can affect canal-leakage rates.

Reach-average leakage rates calculated using the massbalance approach along the moderately low-leakage potential reach of Interstate Canal ranged from 0.1 to $0.7 \mathrm{~m} / \mathrm{d}$. Less variability in leakage from year to year indicates that climatic conditions may have less of an effect for Interstate Canal compared to Tri-State Canal. This may be because Interstate Canal was cut into the northern edge of the North Platte alluvial 


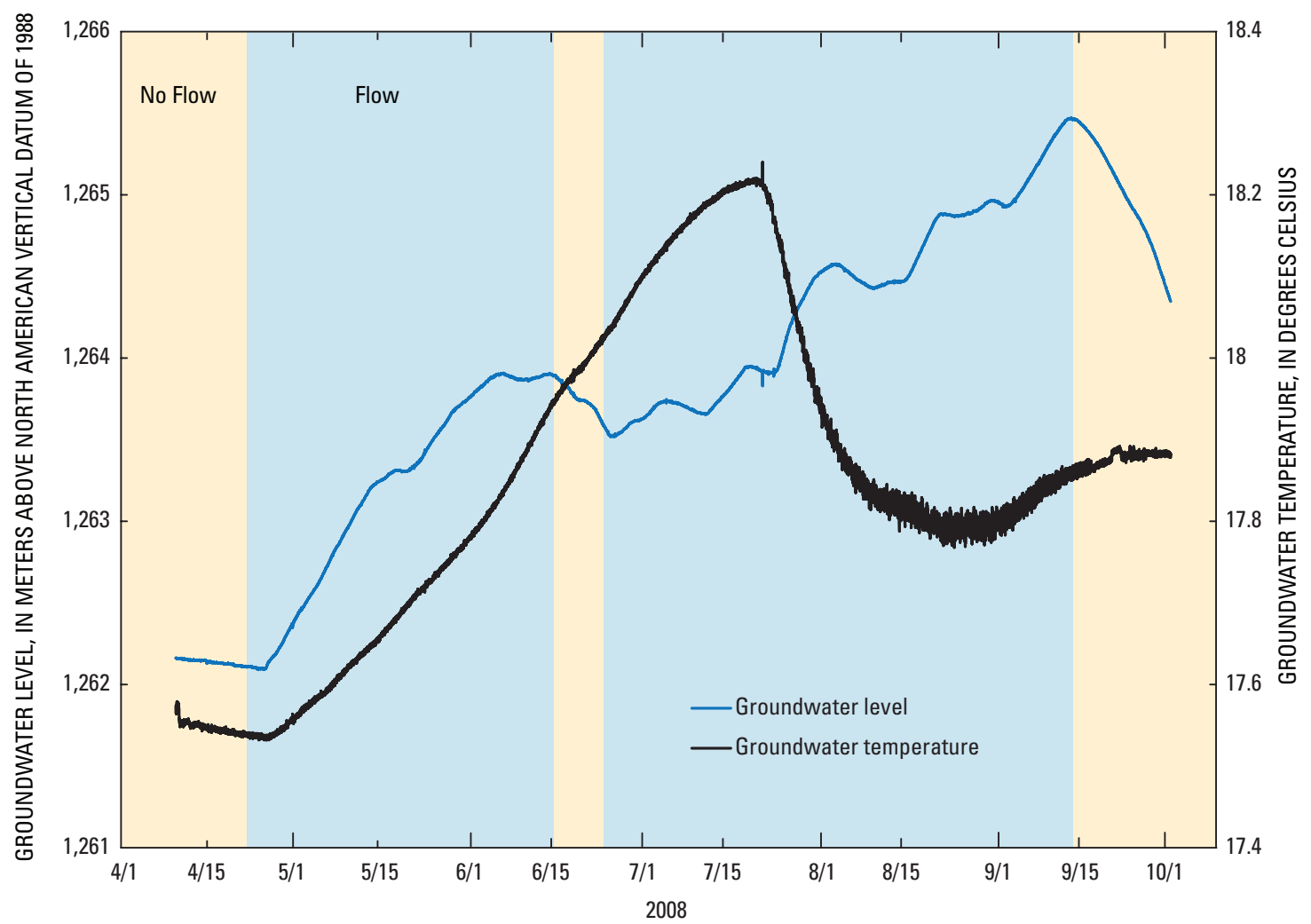

Figure 26. Groundwater level and temperature recorded at monitoring well 420233103441301, Interstate Canal near University Lake, Nebr., April to October, 2008.

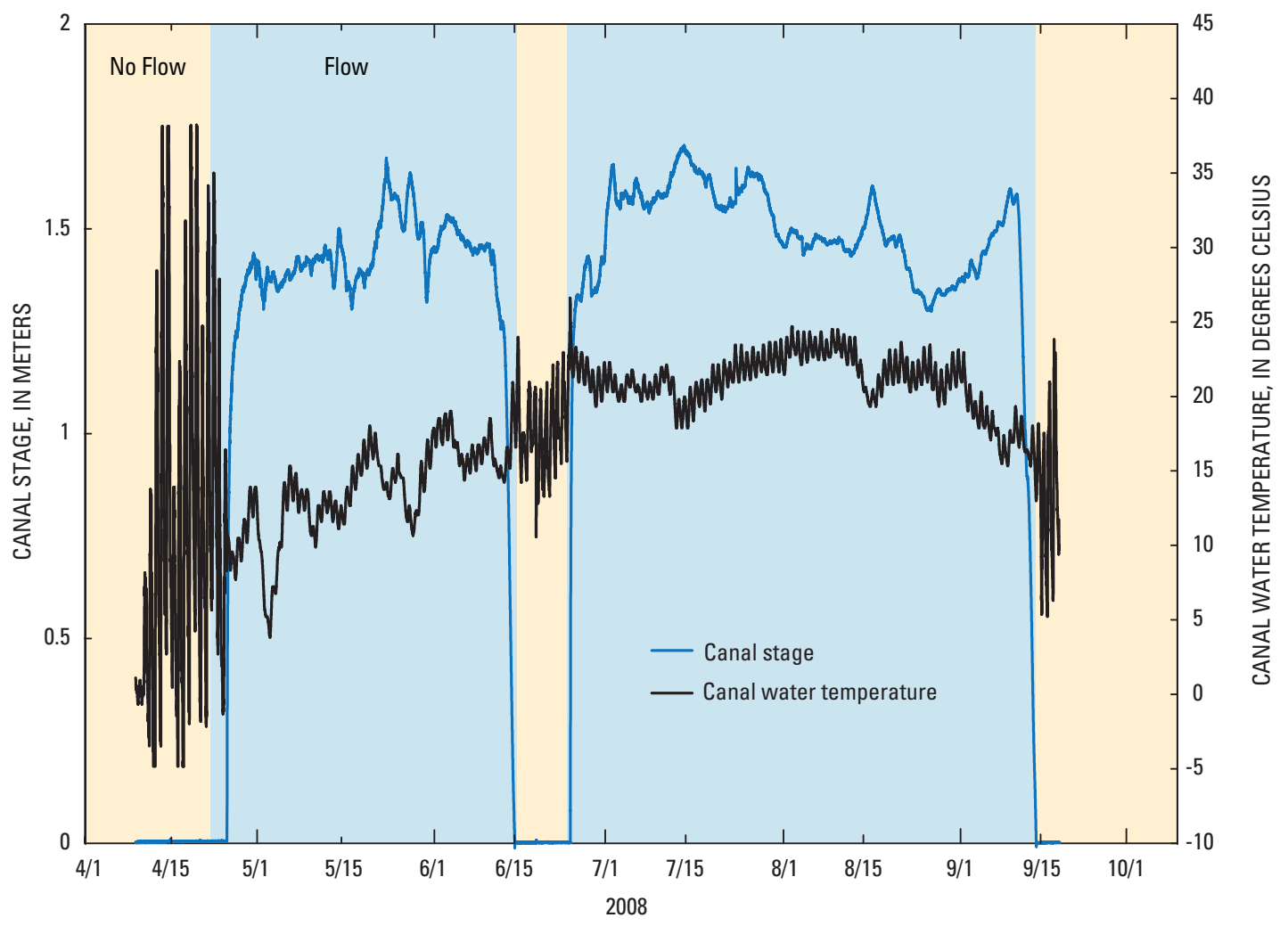

Figure 27. Canal water temperature and stage of Interstate Canal, April to mid-September, 2008. 


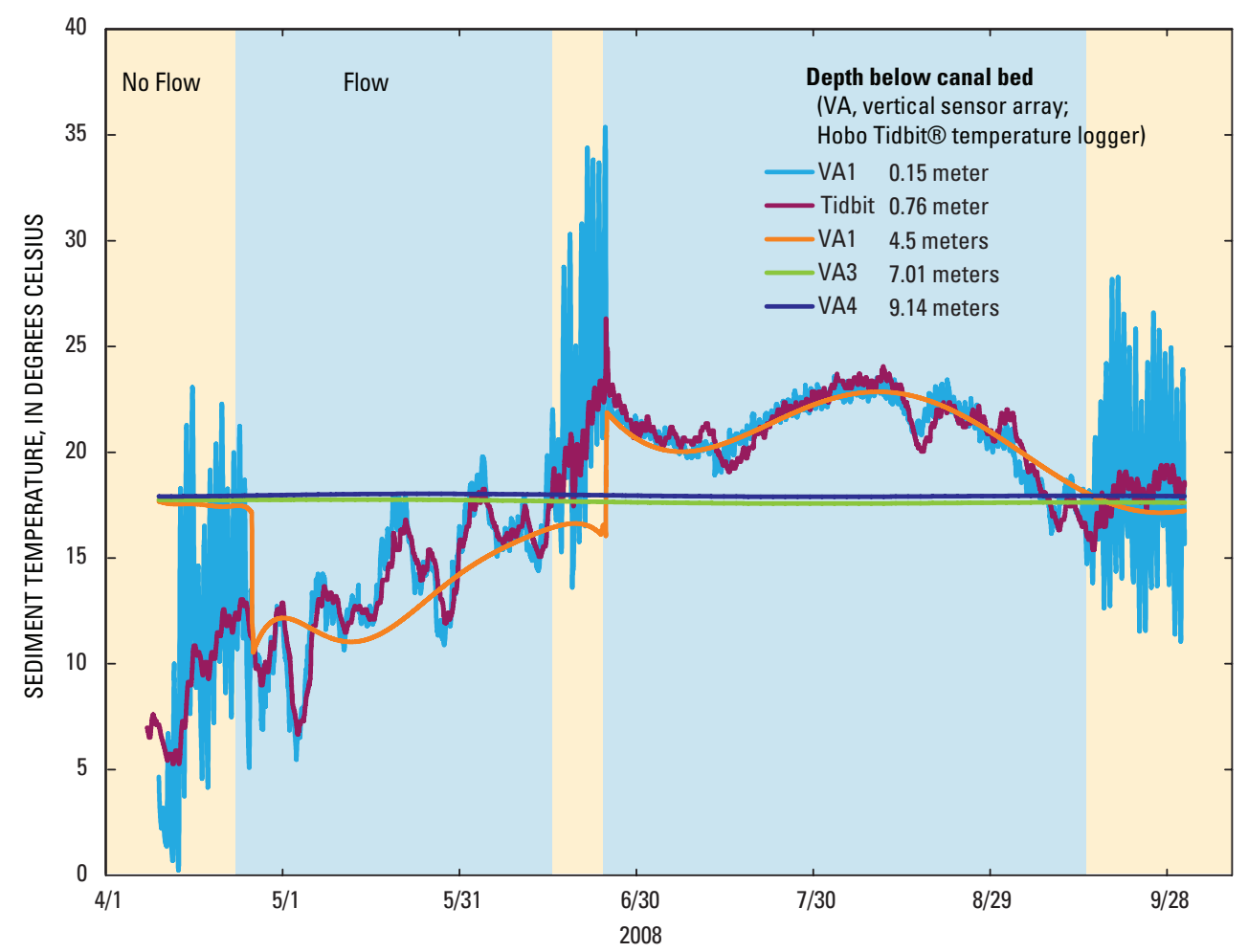

Figure 28. Measured thermographs of sediment beneath Interstate Canal near University Lake, Nebr., from selected depths in vertical sensor arrays, April to October, 2008.

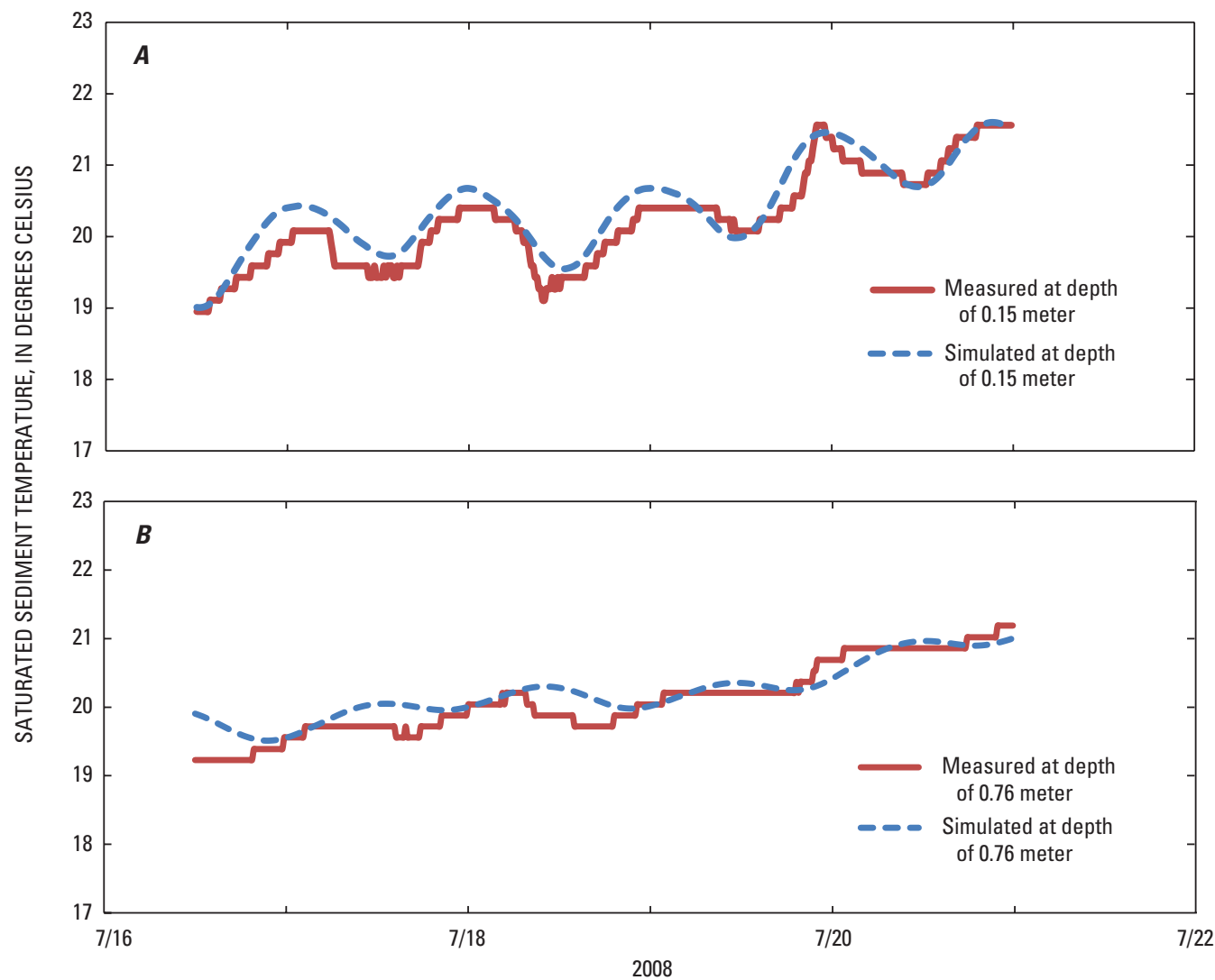

Figure 29. Measured and simulated thermographs for saturated sediment at (A) 0.15 meter and (B) 0.76 meter beneath Interstate Canal near University Lake, Nebraska, July 2008. 
valley and consequently the canal bed is well above the local groundwater table. Interstate Canal also does not receive any captured streamflow that can vary substantially year to year.

Comparing leakage rates calculated from the massbalance approach for the moderately low-leakage potential reach of Interstate Canal to the heat-based estimates requires a mean vertical hydraulic conductivity to be calculated and the hydraulic gradient to be estimated. Based on sediment layer thicknesses and modeled vertical hydraulic conductivities (table 3), a daily leakage rate of $0.74 \mathrm{~m} / \mathrm{d}$ was estimated for site ICTEMP. The vertical hydraulic conductivity of the least permeable layer had the greatest effect on the mean vertical hydraulic conductivity, and therefore, canal leakage. The hydraulic gradient is assumed to be $1 \mathrm{~m} / \mathrm{m}$ because the bed of the canal is well above the water table along the study reach; therefore, the canal-leakage rate at site ICTEMP is estimated to be $0.74 \mathrm{~m} / \mathrm{d}$.

\section{Summary and Conclusions}

The water supply in areas of the North Platte River Basin in the Nebraska Panhandle has been designated as fully appropriated or overappropriated by the Nebraska Department of Natural Resources (NDNR). Enacted legislation (Legislative Bill 962) requires the North Platte Natural Resources District (NPNRD) and the NDNR to develop an Integrated Management Plan (IMP) to balance groundwater and surface-water supply and demand in the NPNRD. A clear understanding of the groundwater and surface-water systems is critical for the development of a successful IMP. The primary source of groundwater recharge in parts of the NPNRD is from irrigation canal leakage. Because canal leakage constitutes a large part of the hydrologic budget, spatially distributing canal leakage to the groundwater system is important to any management strategy. Surface geophysical data collected along selected reaches of irrigation canals has allowed for the spatial distribution of leakage on a relative basis; however, the actual magnitude of leakage remains poorly defined. To address this need, the U.S. Geological Survey, in cooperation with the NPNRD, established streamflow-gaging stations at upstream and downstream ends from two selected canal reaches to allow a mass-balance approach to be used to calculate daily leakage rates. Water-level and sediment temperature data were collected and simulated at three temperature monitoring sites to allow the use of heat as a tracer to estimate the hydraulic conductivity of canal-bed sediment. Canal-leakage rates were estimated by applying Darcy's Law to modeled vertical hydraulic conductivity and either the estimated or measured hydraulic gradient. This approach will improve the understanding of the spatial and temporal variability of canal leakage in varying geologic settings identified in capacitively coupled resistivity surveys.

The high-leakage potential study reach of the Tri-State Canal had two stream gages and two temperature monitoring sites along its length. Streamflow-gaging stations TSUS
(Tri-State Canal near Mitchell, Nebr., site 415812103493701) and TSDS (Tri-State Canal near Mintle, Nebr., site. 415626103434001) were established in 2007 at upstream and downstream locations, respectively, along the study reach of Tri-State Canal. Calculated leakage rates from the massbalance approach varied from year to year and were generally dependent on local climatic conditions, and the timing and magnitude of the initial seasonal diversion into Tri-State Canal. Leakage rates ranged from $0.98 \mathrm{~m} / \mathrm{d}$ on June 22, 2007, to about to $0 \mathrm{~m} / \mathrm{d}$ during July 2009 . Generally speaking, drier local conditions resulted in higher leakage rates. Of the three studied (2007-09), 2007 was the driest with only $23.8 \mathrm{~cm}$ of precipitation recorded the entire year.

The moderately low-leakage potential study reach of Interstate Canal had two stream gages and one temperature monitoring site along its length. Streamflow-gaging stations ISUS (Interstate Canal near Rattlesnake Hill, Nebr., site 420327103464301) and ISDS (Interstate Canal near Mintle, Nebr., site 415922103404801) were established in 2007 at upstream and downstream locations, respectively. Excluding the leakage calculations from early May 2007, the leakage rates ranged from 0.08 to $0.7 \mathrm{~m} / \mathrm{d}$. Less variability in leakage from year to year indicates that climatic conditions may have less of an effect for Interstate Canal compared to Tri-State Canal. This may be because Interstate Canal was cut into the northern edge of the North Platte alluvial valley and consequently the canal bed is well above the local groundwater table resulting in a constant $(1 \mathrm{~m} / \mathrm{m})$ hydraulic gradient. Interstate Canal also does not receive any captured flow that can vary substantially year to year.

Two temperature monitoring sites were installed within the high-leakage potential reach of Tri-State Canal. Site TCTEMP1 was established in 2007 where the water table was well below the canal-bed surface. The vertical hydraulic conductivity of the poorly sorted sand and gravel beneath site TCTEMP1 was estimated using a calibrated one-dimensional VS2DH model. Using a trial-and-error approach, the bestfit vertical hydraulic conductivity for site TCTEMP1 model domain was $1.1 \mathrm{~m} / \mathrm{d}$. Model fits were best for temperature sensors shallower than $0.76 \mathrm{~m}$ when flow was primarily vertical. Below a depth of $0.76 \mathrm{~m}$, flow in canal-bed sediment most likely became multidimensional as measured data display dampened diurnal temperature cycles relative to simulated temperatures. Site TCTEMP2 (Tri-State Canal at Spottedtail Creek, Nebr., site 415834103483701) was established in 2009 at the mouth of Spottedtail Creek where a shallow water table may restrict canal leakage. The mean vertical hydraulic conductivity estimated from the best-fit VS2DH model was 1.5 $\mathrm{m} / \mathrm{d}$; however, measured hydraulic gradients ranged from -0.14 to $-0.07 \mathrm{~m} / \mathrm{m}$, resulting in canal leakage rates that ranged from 0.1 to $0.2 \mathrm{~m} / \mathrm{d}$. Because hydraulic gradient only was collected at one point, it was not appropriate to spatially extrapolate this estimate to other parts of the high-leakage potential reach.

Site ICTEMP (Interstate Canal near University Lake, Nebr., site 420233103441301) is a temperature monitoring site that was established in 2008 to estimate the hydraulic 
conductivity of near-surface sediments, and to understand canal leakage and recharge mechanisms in a fractured Brule setting. Based on the thicknesses and modeled vertical hydraulic conductivities, an average vertical hydraulic conductivity of $0.74 \mathrm{~m} / \mathrm{d}$ was computed. The vertical hydraulic conductivity of the least permeable layer had the greatest effect on the mean vertical hydraulic conductivity, and therefore, canal leakage. The hydraulic gradient is assumed to be $1 \mathrm{~m} / \mathrm{m}$ because the bed of the canal is well above the water table along the study reach; therefore, the canal-leakage rate at site ICTEMP is estimated to be $0.74 \mathrm{~m} / \mathrm{d}$.

\section{References Cited}

Andersen M.P., 2006, Heat as a ground water tracer: Ground Water, v. 43, no. 6, p. 951-968.

Babcock, H.M., and Visher, F.N., 1951, Ground-water conditions in the Dutch Flats area, Scotts Bluff and Sioux Counties, Nebraska, with a section on Chemical quality of the ground water, by W.H. Duram: U.S. Geological Survey Circular 126, $51 \mathrm{p}$.

Ball, L.B., Kress, W.H., Steele, G.V., Cannia, J.C., and Andersen, M.A., 2006, Determination of canal leakage potential using continuous resistivity profiling techniques, Interstate and Tri-State Canals, western Nebraska and eastern Wyoming, 2004: U.S. Geological Survey Scientific Investigations Report 2006-5032, 53 p.

Barrash, Warren, and Morin, R.H., 1987, Hydrostratigraphy and distribution of secondary permeability in the Brule Formation, Cheyenne County, Nebraska: Geological of Society of America Bulletin, v. 99, p. 445-462.

Bishop-Brogden Associates, Inc., 2002, North Platte River return flow study and model: Englewood, Colo., 127 p.

Blasch, K.J., Constantz, James, and Stonestrom, D.A., 2007, Thermal methods for investigating ground-water recharge, in Stonestrom, D.A., Constantz, James, Ferre, T. P.A., and Leake, S.A eds., Ground-water recharge in the arid and semiarid southwestern United States: U.S. Geological Survey Professional Paper 1703, p. 353-376.

Bureau of Reclamation, 1963, Final report-Silting and seepage investigation, North Platte Project, Wyoming-Nebraska: Denver, Colo., Bureau of Reclamation, $180 \mathrm{p}$.

Bureau of Reclamation, 2009a, HYDROMET Data System: Bureau of Reclamation database, accessed February 19, 2010, at http://www.usbr.gov/gp/hydromet/arc050.html.

Bureau of Reclamation, 2009b, North Platte ProjectNebraska and Wyoming: Bureau of Reclamation, Projects and Facilities Database, accessed April 12, 2010, at http://www.usbr.gov/projects/Project. jsp?proj_Name $=$ North + Platte + Project .
Burton, B.L., Johnson, M.R., Vrabel, J., Imig, B.H., Payne, J.D., and Tompkins, R.E., 2009, Capacitively coupled resistivity survey of selected irrigation canals within the North Platte River Valley, western Nebraska, and eastern Wyoming, 2004 and 2007-2009: U.S. Geological Survey Scientific Investigations Report 2009-5194, 70 p.

Center for Advanced Land Management Information Technologies, 2007, 2005 Nebraska land use map: Lincoln, Univ. of Nebraska, CALMIT data, accessed Feb. 14, 2008, at http://www.calmit.unl.edu/2005landuse/statewide.shtml.

Chow, V.T., Maidment, D.R., and Mays, L.W., 1988, Applied hydrology: New York, McGraw-Hill, 572 p.

Cooperative Hydrology Study (COHYST), 2007, COHYST test hole database: Lincoln, Nebr. Dept. of Natural Resources, accessed Feb. 13, 2008, at http://cohyst.dnr. ne.gov/cohyst_preliminarydata.html.

Constantz, James, 2008, Analysis of temperature gradients to determine stream exchanges with ground water, in D.O. Rosenberry, and J.W. LaBaugh, eds., Field techniques for estimating water fluxes between surface water and ground water: U.S. Geological Survey Techniques and Methods 4-D2, p. 115-128.

Constantz, James, Stewart, A.E., Niswonger, Richard, and Sarma, Lisa, 2002, Analysis of temperature profiles for investigating stream losses beneath ephemeral channels: Water Resources Research, v. 38, no. 12, p. 1-13.

Cox, M.H., Su, G.W., and Constantz, James, 2007, Heat, chloride, and specific conductance as ground water tracers near streams: Ground Water, v. 45, no. 2, p. 187-195.

Dages, C., Voltz, M., Lacas, J.G., Huttel, O., Negro, S., and Louchart, X., 2008, An experimental study of water table recharge by seepage losses from a ditch with intermittent flow: Hydrologic Processes, no. 22, p. 3,555-3,563.

Darton, N.H., 1903a, Geologic atlas of the United States, Scotts Bluff folio, Nebraska: U.S. Geological Survey Folio $88,5 \mathrm{p}$.

Darton, N.H., 1903b, Preliminary report on the geology and water resources of Nebraska west of the one hundred and third meridian: U.S. Geological Survey Professional Paper 17, 69 p., 43 pls.

Domenico, P.A., and Schwartz, F.W., 1998, Physical and chemical hydrogeology (2nd ed.): New York, John Wiley and Sons, $506 \mathrm{p}$.

Eddy-Miller, C.A., Wheeler, J.D., and Essaid, H.J., 2009, Characterization of interactions between surface water and near-surface groundwater along Fish Creek, Teton County, Wyoming, by using heat as a tracer: U.S. Geological Survey Scientific Investigations Report 2009-5160, 53 p. 
Essaid, H.I., Zamora, C.M., McCarth, K.A., Vogel, J.R., and Wilson J.T., 2007, Using heat to characterize streambed water flux variability in four stream reaches: Journal of Environmental Quality, v. 36, p. 1-14.

Freeze, R.A., and Cherry, J.A., 1979, Groundwater: Englewood, N.J., Prentice Hall, Inc., 604 p.

Goodwin, C.N., 1979, Effects of the Guernsey silt run upon canal bank stability and seepage: Laramie, Water Resources Research Institute, University of Wyoming, 75 p.

Gutentag, E.D., Heimes, F.J., Krothe, N.C., Luckey, R.R., and Weeks, J.B., 1984, Geohydrology of the High Plains aquifer in parts of Colorado, Nebraska, New Mexico, Oklahoma, South Dakota, Texas, and Wyoming: U.S. Geological Survey Professional Paper 1400-B, 63 p.

Harvey, F.E., and Sibray, S.S., 2001, Delineating ground water recharge from leaking irrigation canals using water chemistry and isotopes: Ground Water, v. 39, no. 3, p. 408-421.

Healy, R.W., 2008, Simulating water, solute, and heat transport in the subsurface with the VS2DI software package: Vadose Zone Journal, v. 7, no. 2, p. 632-639.

Healy, R.W., and Ronan, A.D., 1996, Documentation of computer program VS2DH for simulation of energy transport in variably saturated porous media-Modification of the U.S. Geological Survey's computer program VS2DT: U.S. Geological Survey Water-Resources Investigations Report 96-4230, 40 p.

Hobza, C.M., 2008, Continuous temperature and water-level data collected for a heat tracer study on a selected reach of Tri-State Canal, western Nebraska, 2007: U.S. Geological Survey Data Series 2008-381, 22 p.

Hoffman, J.P., Blasch, K.W., Pool, D.R., Bailey, M.A., and Callegary, J.B., 2007, Estimated infiltration, percolation, and recharge rates at the Rillito Creek focused recharge investigation site, Pima County, Arizona, in Stonestrom, D.A., Constantz, James, Ferre, T. P.A., and Leake, S.A, eds., Ground-water recharge in the arid and semiarid southwestern United States: U.S. Geological Survey Professional Paper 1703, p. 185-220.

Lapalla, E.G., Healy, R.W., and Weeks, E.P., 1987, Documentation of computer program VS2D to solve the equations of fluid flow in variably saturated porous media: U.S. Geological Survey Water-Resources Investigations Report 83-4099, 184 p.

Luckey, R.R., and Cannia, J.C., 2006, Ground water flow model of the western model unit of the Nebraska Cooperative Hydrology Study (COHYST) area: Lincoln, Nebr. Dept. of Natural Resources, 63 p., accessed February 2008, at http://cohyst.dnr.ne.gov/adobe/dc012WMU_ GFMR_060519.pdf.
Mihevc, Todd, Pohll, Greg, Niswonger, Rich, and Stevick, Elizabeth, 2002, Truckee Canal seepage analysis in the Fernley/Wadsworth area: Las Vegas, Nev., Desert Research Institute, Publication No. 41176, 44 p.

Morlock, S.E., Nguyen, H.T., and Ross, J.H., 2002, Feasibility of acoustic Doppler velocity meters for the production of discharge records from U.S. Geological Survey streamflowgaging stations: U.S. Geological Survey Water-Resources Investigations Report 01-4157, 56 p.

Mueller, D.S., and Wagner, C.R., 2009, Measuring discharge with acoustic Doppler current profilers from a moving boat: U.S. Geological Survey Techniques and Methods 3A-22, $72 \mathrm{p}$.

National Oceanic and Atmospheric Administration, 2007, Climatological data annual summary, Nebraska, 2006: National Climatic Data Center, Climatological Data, v. 111, no. 13,34 p.

National Oceanic and Atmospheric Administration, 2010, Climatological data annual summary, 2009: National Climatic Data Center, accessed March 1, 2010, at http://gis. ncdc.noaa.gov/website/ims-cdo/sod/viewer.htm.

Nebraska Department of Natural Resources, 2009, Fifty-fifth biennial report of the Department of Natural Resources: Lincoln, Nebr., 675 p., accessed February 11, 2010, at http://www.dnr.state.ne.us/SurfaceWater/BiennialReport/ BiennialReport_2009_Ver1.pdf.

Niswonger, R.G., and Prudic, D.E., 2003, Modeling heat as a tracer to estimate stream seepage and hydraulic conductivity, in eds. Constantz, Jim, and Stonestrom, D.A., Heat as a tool for studying the movement of ground water near streams: U.S. Geological Survey Circular 1260, p. 81-89.

Omega Engineering, 2010, Revised thermocouple reference tables - Type T: Stamford, Conn., Omega Engineering, accessed April 13, 2008, at http://www.omega.com/ temperature/Z/pdf/z207.pdf.

Omega Engineering, 2008, Revised thermocouple reference tables - Type E: Stamford, Conn., Omega Engineering, accessed April 25, 2008, at http://www.omega.com/ temperature/Z/pdf/z206.pdf.

Ostdiek, Amy, 2009, The integrated management planning process: Lincoln, Nebr., Nebraska Dept. of Natural Resources, Water Matters, no. 1., 4 p., accessed September 20, 2010, at http://www.dnr.state.ne.us/IWM/WaterMatters/ WaterMatters_No1.pdf.

Rantz, S.E., 1982, Measurement and computation of streamflow: v. 2, Computation and discharge: U.S. Geological Survey Water-Supply Paper 2175, p. 285-631.

Rehmel, M.S., 2002, AreaComp.exe, version 1.1, U.S. Geological Survey software http://hydroacoustics.usgs.gov/ indexvelocity/software.shtml. 
Robinson, A.R., and Rohwer, Carl, 1957, Measurement of canal seepage: Transactions of the American Society of Civil Engineers, v. 122, p. 347-373.

Robinson, A.R., and Rohwer, Carl, 1959, Measuring seepage from irrigation channels: US Department of Agriculture Technical Bulletin 1203, 82 p.

Ronan, A.D., Prudic, D.E., Thodal, C.E., and Constantz, J., 1998, Field study and simulation of diurnal temperature effects on infiltration and variably saturated flow beneath an ephemeral stream: Water Resources Research, v. 34, no. 9, p. 2,137-2,153.

Ruhl, C.A., and Simpson, M.R., 2005, Computation of discharge using the index-velocity method in tidally affected areas: U.S. Geological Survey Scientific Investigations Report 2005-5004, 31 p.

Sibray, S.S., and Zhang, Y.K., 1994, Three-dimensional modeling of hydraulic behavior of a highly conductive secondary permeability zone in the Brule Formation, in Proceedings of the 1994 Groundwater Modeling Conference, eds. J.W. Wagner and P. van der Heijde, Fort Collins, Colo., Colorado State University, p. 445-452.

Sophocleous, Marlos, Koussis, Antonis, Martin, J.L, and Perkins, S.P., 1995, Evaluation of simplified stream-aquifer depletion models for water rights administration: Ground Water, v. 33, no. 4, p. 579-588.

Steele, G.V., Verstraeten, I.M., and Cannia, J.C., 2001, Surface-water/ground-water interaction and implications for ground-water sustainability in the Dutch Flats area, western Nebraska: U.S. Geological Survey Fact Sheet 074-01, 4 p.

Stephens, D.B., Cox, Warren, and Halvena, Jeffery, 1988, Field study of ephemeral stream infiltration and recharge: New Mexico Water Resources Research Institute, Tech. Completion Report No. 228, New Mexico State University, Las Cruces, N.M., 187 p.

Stephens, D.B., 1996, Vadose zone hydrology: Boca Raton, Florida, CRC Press Inc., 347 p.

Stonestrom, D.A., and Blasch, K.W., 2003, Determining temperature and thermal properties for heat-based studies of surface-water ground-water interactions, in Stonestrom, D.A., and Constantz, James, eds., Heat as a tool for studying the movement of ground water near streams: U.S. Geological Survey Circular 1260, p. 73-80.
Stonestrom, D.A., Constantz, James, Ferre, T.P.A., Leake, S.A., eds., 2007, Ground-water recharge in the arid southwestern United States: U.S. Geological Survey Professional Paper 1703, 414 p.

Stonestrom, D.A., and Constantz, James, 2003, Heat as a tool for studying the movement of ground water near streams: U.S. Geological Survey Circular 1260, 96 p.

Swinehart, J.B., and Diffendahl, R.F., Jr., 1997, Geologic map of the Scottsbluff $1^{\circ}$ x $2^{\circ}$ quadrangle, Nebraska and Colorado: U.S. Geological Survey Miscellaneous Investigations Map I-12545, scale 1:250,000, 21 p.

Verstraeten, I.M., Bohlke, J.K., Kraemer, T.F., and Cannia, J.C., 2002, Use of environmental tracers and isotopes to evaluate sources of water, nitrate, and uranium in an irrigated alluvial valley, Nebraska: U.S. Geological Fact Sheet 100-01, 4 p.

Verstraeten, I.M., Sibray, S.S., Cannia, J.C., and Tanner, D.Q., 1995, Reconnaissance of ground-water quality in the North Platte Natural Resources District, western Nebraska, June-July 1991: U.S. Geological Survey Water-Resources Investigations Report 94-4057, 114 p.

Verstraeten, I.M., Steele, G.V., Cannia, J.C., Hitch, D.E., Scripter, K.G., Bohlke, J.K., Kraemer, T.F., and Stanton, J.S., 2001, Interactions of Surface Water and Ground Water in the Dutch Flats Area, Western Nebraska, 1995-99: U.S. Geological Survey Water-Resources Investigations Report 01-4070, 56 p.

Wenzel, L.K., Cady, R.C., and Waite, H.A., 1946, Geology and ground-water resources of Scotts Bluff County, Nebraska: U.S. Geological Survey Water-Supply Paper 943, $150 \mathrm{p}$.

Winters, T.C., Harvey, J.W., Franke, O.L., and Alley, W.M., 1998, Ground water and surface water: a single resource: U.S. Geological Survey Circular 1139, 80 p.

X-rite Inc., 2000, Munsell soil color charts: Grand Rapids, Mich, $10 \mathrm{p}$.

Zamora, Celia, 2008, Estimating water fluxes across the sediment-water interface in the Lower Merced River, California: U.S. Geological Survey Scientific Investigations Report 2007-5216, 47 p. 


\section{Appendix 1-Sediment Core Locations and Lithologic Descriptions}


Blank Page 
Appendix 1. Sediment core locations and lithologic descriptions of vertical sensor arrays at temperature monitoring sites.

[site names: TCTEMP1, Tri-State Canal near Mitchell, site number 415542103455301; TCTEMP2, Tri-State Canal at Spottedtail Creek, site number 41583410348370; ICTEMP, Interstate Canal near University Lake, site number 420233103441301; Legal descriptions: T., township; R., range; S., section; $\mathrm{ABCD}$, for example, are codes for the quarter section, quarter-quarter section, quarter-quarter-quarter section, and quarter-quarter-quarter-quarter section; $\mathrm{A}, \mathrm{B}, \mathrm{C}$, and D, respectively, where A is northeast, B is northwest, $\mathrm{C}$ is southwest, and D is southeast quarter of the next larger unit; Munsell color codes from $\mathrm{X}$-rite, 2000; \%, percent; cm, centimeter; $\mathrm{m}$, meter]

\begin{tabular}{|c|c|c|}
\hline $\begin{array}{l}\text { Depth interval, } \\
\text { in meters below } \\
\text { canal-bed surface }\end{array}$ & Lithology of indicated core interval at indicated site & $\begin{array}{c}\text { Munsell color } \\
\text { (color description) }\end{array}$ \\
\hline
\end{tabular}

TCTEMP1 - Vertical sensor array 1 (location T.23N R.56W S.36BAAA or latitude $41.92826^{\circ} \mathrm{N}$, longitude $103.76466^{\circ} \mathrm{W}$ )

0-0.55 No sample

0.55-1.16 Sand, medium, moderately sorted, well rounded to rounded, interbedded coarse sand to fine gravel, rounded to sub-angular, range $(0.48-1.90 \mathrm{~cm})$, lenses of clayey silt, dark brown, medium plasticity, $85 \%$ quartz, $10 \%$ feldspar, $5 \%$ mafic

1.16-1.38 No sample

1.38-1.97 Sand, medium to coarse, poorly sorted, well rounded to rounded, interbedded fine to coarse gravel, rounded to sub-angular, range $(0.48-3.81 \mathrm{~cm}), 85 \%$ quartz, $10 \%$ feldspar, $5 \%$ mafic

1.97-2.0 Clayey silt, medium plasticity

$2.5 Y 5 / 3$

2.0-2.4 Sand, medium to coarse, poorly sorted, well rounded to rounded, interbedded fine gravels, rounded, range $(0.48-1.90 \mathrm{~cm}), 75 \%$ quartz, $20 \%$ feldspar, $5 \%$ mafic

2.4-3.6 Sand, medium to coarse, poorly sorted, well rounded to rounded, interbedded fine to coarse gravel, rounded, range $(0.48-2.54 \mathrm{~cm}), 85 \%$ quartz, $10 \%$ feldspar, $5 \%$ mafic

3.6-3.8 No sample

3.8-4.1 Sand, fine to medium, well rounded to rounded, poorly sorted, traces of organic silt, dark brown, interbedded fine to coarse gravel, rounded to sub-angular, range $(0.48-2.54 \mathrm{~cm}), 90 \%$ quartz, $5 \%$ feldspar, $5 \%$ mafic

4.1-4.4 Sand, fine, well sorted, well rounded, interbedded medium to coarse sand, rounded, 95\% quartz, $2 \%$ feldspar, $3 \%$ mafic

4.4-4.8 Sand, medium to coarse, well rounded to rounded, poorly sorted, interbedded fine to coarse gravel, rounded to sub-angular, range $(0.48-2.03 \mathrm{~cm}), 90 \%$ quartz, $5 \%$ feldspar, $5 \%$ mafic

4.8-6.0 Sand, medium to coarse, well rounded to rounded, poorly sorted, interbedded fine to coarse gravel, rounded to sub-angular, range $(0.48-1.90 \mathrm{~cm}), 85 \%$ quartz, $10 \%$ feldspar, $5 \%$ mafic

TCTEMP1 - Vertical sensor array 2 (location T.23N R.56W S.36BAAA or latitude $41.92828^{\circ} \mathrm{N}$, longitude $103.76472^{\circ} \mathrm{W}$ )

0-0.44 No sample

0.44-0.61 Sand, fine to medium, moderately sorted, well rounded to rounded, traces of intermixed clayey silt, brown, medium plasticity, interbedded coarse sand to fine gravel, rounded, range $(0.20-1.27 \mathrm{~cm})$, $90 \%$ quartz, $5 \%$ feldspar, $5 \%$ mafic

0.61-1.16 Sand, medium to coarse, poorly sorted, well rounded to rounded, interbedded fine gravel, rounded, range $(0.48-1.27 \mathrm{~cm}), 80 \%$ quartz, $15 \%$ feldspar, $5 \%$ mafic

1.16-1.33 No sample

1.33-1.72 Sand, medium to coarse, poorly sorted, well rounded to rounded, interbedded fine to coarse gravel, rounded to sub-angular, range $(0.48-2.54 \mathrm{~cm}), 80 \%$ quartz, $15 \%$ feldspar, $5 \%$ mafic 
Appendix 1. Sediment core locations and lithologic descriptions of vertical sensor arrays at temperature monitoring sites.-Continued

[site names: TCTEMP1, Tri-State Canal near Mitchell, site number 415542103455301; TCTEMP2, Tri-State Canal at Spottedtail Creek, site number 41583410348370; ICTEMP, Interstate Canal near University Lake, site number 420233103441301; Legal descriptions: T., township; R., range; S., section; $\mathrm{ABCD}$, for example, are codes for the quarter section, quarter-quarter section, quarter-quarter-quarter section, and quarter-quarter-quarter-quarter section; A, B, C, and D, respectively, where A is northeast, B is northwest, C is southwest, and D is southeast quarter of the next larger unit; Munsell color codes from $\mathrm{X}$-rite, 2000; \%, percent; cm, centimeter; m, meter]

\begin{tabular}{|c|c|c|}
\hline $\begin{array}{l}\text { Depth interval, } \\
\text { in meters below } \\
\text { canal-bed surface }\end{array}$ & Lithology of indicated core interval at indicated site & $\begin{array}{c}\text { Munsell color } \\
\text { (color description) }\end{array}$ \\
\hline
\end{tabular}

TCTEMP1 - Vertical sensor array 2 (location T.23N R.56W S.36BAAA or latitude $41.92828^{\circ} \mathrm{N}$, longitude $103.76472^{\circ} \mathrm{W}$ )—Continued

1.72-2.4 Sand, fine to medium, moderately sorted, well rounded, interbedded coarse sand to fine gravel,

$2.5 \mathrm{Y} 7 / 3$ rounded to sub-angular, range $(0.20-1.27 \mathrm{~cm})$, trace of intermixed clay, light brown, medium plasticity, occasional coarse gravel, angular, range $(2.54-3.81 \mathrm{~cm}), 90 \%$ quartz, $5 \%$ feldspar, $5 \%$ mafic

2.4-2.75 Sand, fine, well sorted, well rounded, occasional interbedded coarse sand to fine gravel, rounded to sub-angular, range $(0.20-1.27 \mathrm{~cm}), 90 \%$ quartz, $5 \%$ feldspar, $5 \%$ mafic

2.75-3.3 Sand, fine to medium, poorly sorted, well rounded to rounded, interbedded coarse sand to fine to coarse gravel, rounded to sub-angular, range $(0.20-1.27 \mathrm{~cm})$, lenses of clayey silt, light brown, medium plasticity, $2.54 \mathrm{~cm}$ in length, $85 \%$ quartz, $10 \%$ feldspar, $5 \%$ mafic

3.3-3.6 Sand, fine to medium, well sorted, well rounded to rounded, occasional interbedded fine gravel, rounded, $90 \%$ quartz, $5 \%$ feldspar, $5 \%$ mafic

3.6-4.0 Sand, fine to medium, well rounded to rounded, poorly sorted, interbedded coarse sand to fine gravel, rounded to sub-angular, range $(0.20-1.27 \mathrm{~cm}), 85 \%$ quartz, $10 \%$ feldspar, $5 \%$ mafic

4.0-4.3 Sand, fine, well sorted, well rounded to rounded, occasional interbedded fine gravel, rounded to sub-angular, $95 \%$ quartz, $2 \%$ feldspar, $3 \%$ mafic

4.3-4.8 Sand, medium to coarse, rounded to sub-angular, poorly sorted, interbedded fine to coarse gravel,

$2.5 Y 7 / 3$ rounded to sub-angular, range $(0.20-3.81 \mathrm{~cm}), 80 \%$ quartz, $15 \%$ feldspar, $5 \%$ mafic

4.8-5.0 No sample

5.0-5.9 Sand, fine to medium, well rounded to rounded, poorly sorted, interbedded coarse sand to fine gravel, rounded to sub-angular, range $(0.20-1.27 \mathrm{~cm}), 80 \%$ quartz, $15 \%$ feldspar, $5 \%$ mafic

5.9-6.0 Sand, fine, well sorted, well rounded, 95\% quartz, $2 \%$ feldspar, $3 \%$ mafic

TCTEMP1 - Vertical sensor array 3 (location T.23N R.56W S.36BAAA or latitude $41.92825^{\circ} \mathrm{N}$, longitude $103.76469^{\circ} \mathrm{W}$ )

0-0.21 No sample

0.21-1.16 Sand, medium to coarse, poorly sorted, well rounded, interbedded fine to coarse gravel, range $(0.48-3.81 \mathrm{~cm})$, contains a lense of silty clay, fine, medium plasticity, $85 \%$ quartz, $10 \%$ feldspar, $5 \%$ mafic

1.16-2.4 Sand, fine to medium, poorly sorted, well rounded to rounded, interbedded coarse sand to fine to coarse gravel, rounded to sub-angular, range $(0.48-5.08 \mathrm{~cm}), 85 \%$ quartz, $10 \%$ feldspar, $5 \%$ mafic

2.4-2.6 No sample

2.6-3.3 Sand, fine to medium, poorly sorted, well rounded to rounded, interbedded coarse sand to fine to coarse gravel, rounded to sub-angular, range $(0.48-2.03 \mathrm{~cm}), 85 \%$ quartz, $10 \%$ feldspar, $5 \%$ mafic

3.3-3.6 Sand, fine to medium, well sorted, well rounded, $95 \%$ quartz, $2 \%$ feldspar, $3 \%$ mafic

TCTEMP1 - Vertical sensor array 4 (location T.23N R.56W S.36BAAA or latitude $41.92831^{\circ} \mathrm{N}$, longitude $103.76467^{\circ} \mathrm{W}$ )

0-0.35 No sample

0.35-0.67 Sand, fine, moderately sorted, well rounded to rounded, interbedded medium sand, rounded to subangular, traces of clayey silt, organic, medium plasticity, $95 \%$ quartz, $3 \%$ feldspar, $2 \%$ mafic

0.67-1.16 Sand, medium, poorly sorted, well rounded to rounded, interbedded coarse sand to fine gravel, rounded to sub-angular, $90 \%$ quartz, $5 \%$ feldspar, $5 \%$ mafic 
Appendix 1. Sediment core locations and lithologic descriptions of vertical sensor arrays at temperature monitoring sites.-Continued

[site names: TCTEMP1, Tri-State Canal near Mitchell, site number 415542103455301; TCTEMP2, Tri-State Canal at Spottedtail Creek, site number 41583410348370; ICTEMP, Interstate Canal near University Lake, site number 420233103441301; Legal descriptions: T., township; R., range; S., section; $\mathrm{ABCD}$, for example, are codes for the quarter section, quarter-quarter section, quarter-quarter-quarter section, and quarter-quarter-quarter-quarter section; $\mathrm{A}, \mathrm{B}, \mathrm{C}$, and D, respectively, where A is northeast, B is northwest, $\mathrm{C}$ is southwest, and D is southeast quarter of the next larger unit; Munsell color codes from $\mathrm{X}$-rite, 2000; \%, percent; cm, centimeter; m, meter]

\begin{tabular}{|c|c|c|}
\hline $\begin{array}{l}\text { Depth interval, } \\
\text { in meters below } \\
\text { canal-bed surface }\end{array}$ & Lithology of indicated core interval at indicated site & $\begin{array}{c}\text { Munsell color } \\
\text { (color description) }\end{array}$ \\
\hline
\end{tabular}

TCTEMP1 - Vertical sensor array 4 (location T.23N R.56W S.36BAAA or latitude $41.92831^{\circ} \mathrm{N}$, longitude $103.76467^{\circ} \mathrm{W}$ )—Continued

1.16-1.4 No sample

1.4-2.2 Sand, medium, poorly sorted, well rounded to rounded, interbedded coarse sand, fine to coarse gravel, rounded to sub-angular, range $(0.48-3.81 \mathrm{~cm})$, lenses of medium sand, well sorted, well rounded, $90 \%$ quartz, $5 \%$ feldspar, $5 \%$ mafic

2.2-2.4 Sand, fine to medium, well sorted, well rounded, occasional interbedded coarse sand, rounded, $90 \%$ quartz, $5 \%$ feldspar, $5 \%$ mafic

2.4-3.3 Sand, fine to medium, poorly sorted, well rounded to rounded, interbedded, coarse sand, rounded, fine to coarse gravel, rounded to sub-angular, range $(0.48-3.81 \mathrm{~cm}), 90 \%$ quartz, $5 \%$ feldspar, $5 \%$ mafic

3.3-3.6 Sand, medium to coarse, poorly sorted, rounded to sub-angular, interbedded fine gravel, rounded to sub-angular, range $(0.48-1.90 \mathrm{~cm}), 80 \%$ quartz, $15 \%$ feldspar, $5 \%$ mafic TCTEMP2 - (location T.23N R.56W S.10CBDC or latitude $41.97611^{\circ} \mathrm{N}$, longitude $-103.81028^{\circ} \mathrm{W}$ )

0-0.41 No sample

0.41-0.58 Sand, medium, moderately sorted, well rounded, saturated, 95\% quartz, $2 \%$ feldspar, $3 \%$ mafic saturated, $95 \%$ quartz, $2 \%$ feldspar, $3 \%$ mafic

0.74-0.91 Sand, fine, well sorted, well rounded, saturated, $90 \%$ quartz, $10 \%$ mafic

$2.5 Y 5 / 1$

ICTEMP - Vertical sensor array 1 (location T.24N R.55W S.20BBCB or latitude $42.0429^{\circ} \mathrm{N}$, longitude $103.73714^{\circ} \mathrm{W}$ )

0-0.80 No sample

0.80-1.16 Sand, medium, rounded, moderately sorted, interbedded coarse sand, rounded to sub-rounded, $90 \%$ quartz, $5 \%$ feldspar, $5 \%$ mafic

1.16-1.99 No sample

1.99-2.32 Silt, fine, sandy silt towards the top, sand content decreases with depth (5\% sand), silt is more compacted than previous interval, hard, soft when broken apart

2.32-3.48 Silt, soft, slight sand content (5\%), 90\% quartz, 5\% feldspar, 5\% mafic

10YR 6/4

3.48-3.98 Sandy silt, medium, (40\% sand), rounded, 90\% quartz, 5\% feldspar, 5\% mafic

10YR 5/4

$3.98-4.64$

Silt, soft, slight sand content (5\%), 90\% quartz, 5\% feldspar, 5\% mafic, mafic content increases to

10YR 5/4 $10-15 \%$ toward the bottom

\begin{tabular}{l}
\hline ICTEMP - Vertical sensor array 2 (location T.24N R.55W S.20BBCB or latitude $42.04285^{\circ}$ N, longitude $103.73714^{\circ}$ W) \\
\hline $0-0.51$ No sample
\end{tabular}

0.51-0.88 Sand, medium, poorly sorted, rounded to sub-rounded, interbedded coarse sand to fine gravel, sub-rounded, occasional coarse gravel, sub-rounded, range $(1.9-3.5 \mathrm{~cm})$, clayey silt lense at $0.84 \mathrm{~m}(2.5 \mathrm{Y} 4 / 2)$, sand becomes finer from $0.84-0.88 \mathrm{~m}, 80 \%$ quartz, $15 \%$ feldspar, $5 \%$ mafic

0.88-0.94 Clayey silt, dark brown (20-25\% clay) 
Appendix 1. Sediment core locations and lithologic descriptions of vertical sensor arrays at temperature monitoring sites. - Continued

[site names: TCTEMP1, Tri-State Canal near Mitchell, site number 415542103455301; TCTEMP2, Tri-State Canal at Spottedtail Creek, site number 41583410348370; ICTEMP, Interstate Canal near University Lake, site number 420233103441301; Legal descriptions: T., township; R., range; S., section; $\mathrm{ABCD}$, for example, are codes for the quarter section, quarter-quarter section, quarter-quarter-quarter section, and quarter-quarter-quarter-quarter section; $\mathrm{A}, \mathrm{B}, \mathrm{C}$, and D, respectively, where A is northeast, B is northwest, $\mathrm{C}$ is southwest, and D is southeast quarter of the next larger unit; Munsell color codes from $\mathrm{X}$-rite, 2000; \%, percent; cm, centimeter; m, meter]

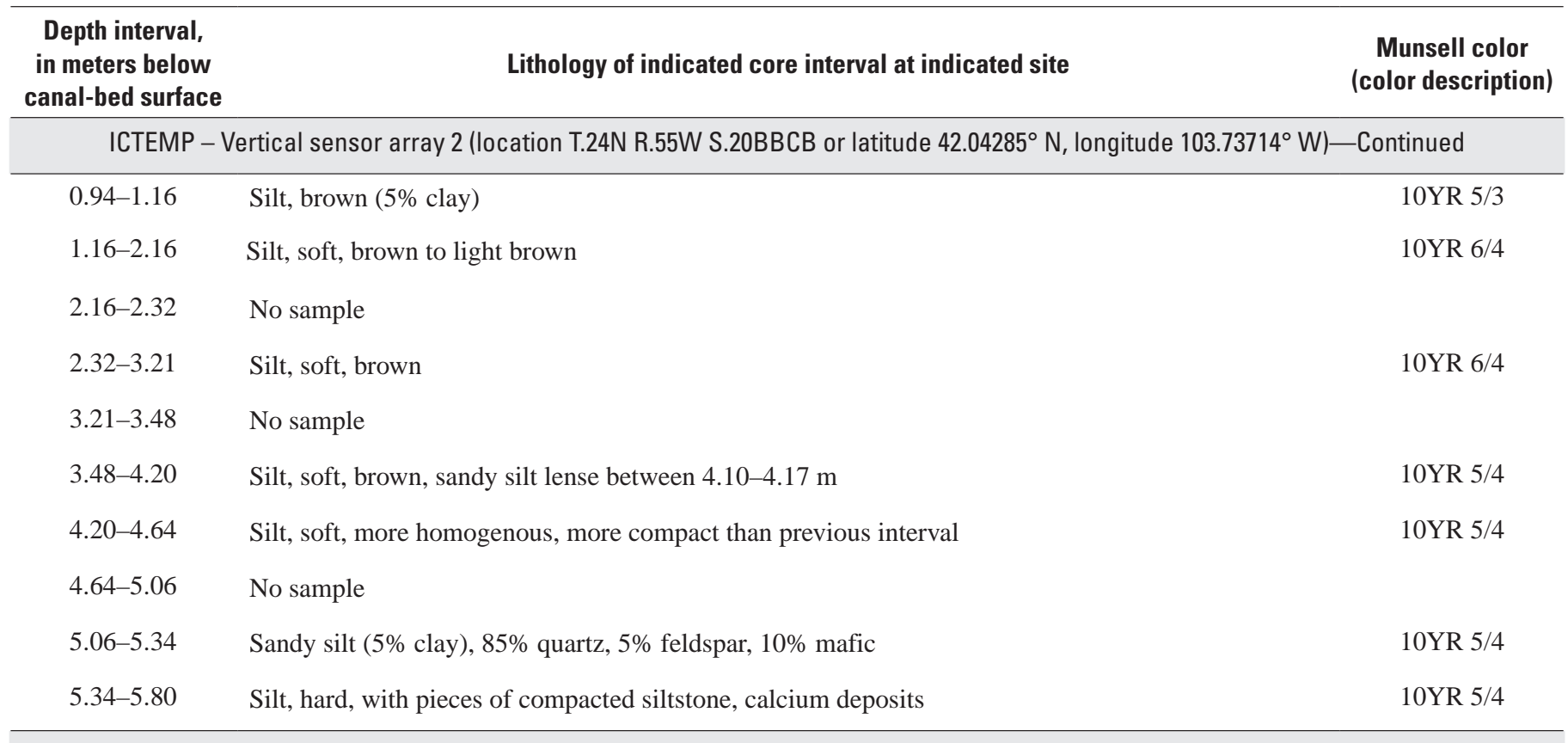

ICTEMP - Vertical sensor array 3 (location T.24N R.55W S.20BBCB or latitude $42.04269^{\circ} \mathrm{N}$, longitude $103.73722^{\circ} \mathrm{W}$ )

0-1.16 Sandy silt, fine, 10-15\% sand, soft, occasional interbedded siltstone chips, white, interbedded roots, 10YR 6/4 sand content decreases below $0.60 \mathrm{~m}$ to $5 \%$ sand, $90 \%$ quartz, $5 \%$ feldspar, $5 \%$ mafic

1.16-1.74 No sample

1.74-2.32 Silt, fine, soft, slight sand content (5\% fine sand), some interbedded roots, 90\% quartz, 5\% feldspar, 10 YR 6/4 $5 \%$ mafic

2.32-3.48 No sample

3.48-4.64 Silt, soft, slight sand content (5\% fine sand), $90 \%$ quartz, $5 \%$ feldspar, $5 \%$ mafic

10YR 6/4

4.64-5.14 No sample

5.14-5.8 Silt, soft, slight sand content (5\% fine sand), 90\% quartz, 5\% feldspar, 5\% mafic

10YR 6/4

5.8-6.96 Silt, soft, slightly more sand content (5-10\% fine sand), 85\% quartz, 5\% feldspar, 10\% mafic

10YR 6/4

6.96-8.12 Silt, darker color than previous interval, more weathered

10YR 5/4

8.12-8.92 Silt, harder, chunky, occasional appearance of interbedded siltstone chips, hard

10YR 5/4

8.92-9.2 Silt, hard, chunky, greater appearance of siltstone chips, hard

10YR 5/4

ICTEMP - Vertical sensor array 4 (location T.24N R.55W S.20BBCB or latitude $42.04264^{\circ} \mathrm{N}$, longitude $-103.73726^{\circ} \mathrm{W}$ )

0-0.26 No sample

0.26-0.57 Sandy silt, fine, interbedded roots, $85 \%$ quartz, $5 \%$ feldspar, $10 \%$ mafic

$2.5 Y 6 / 4$

0.57-1.16 Sandy silt, fine, $10 \%$ fine sand, interbedded roots, $90 \%$ quartz, $5 \%$ feldspar, $5 \%$ mafic

$2.5 Y 7 / 4$

1.16-1.57 No sample

1.57-2.32 Silt, soft, fine, sand content (5-10\%), silt becomes more compacted below $2 \mathrm{~m}, 90 \%$ quartz, 

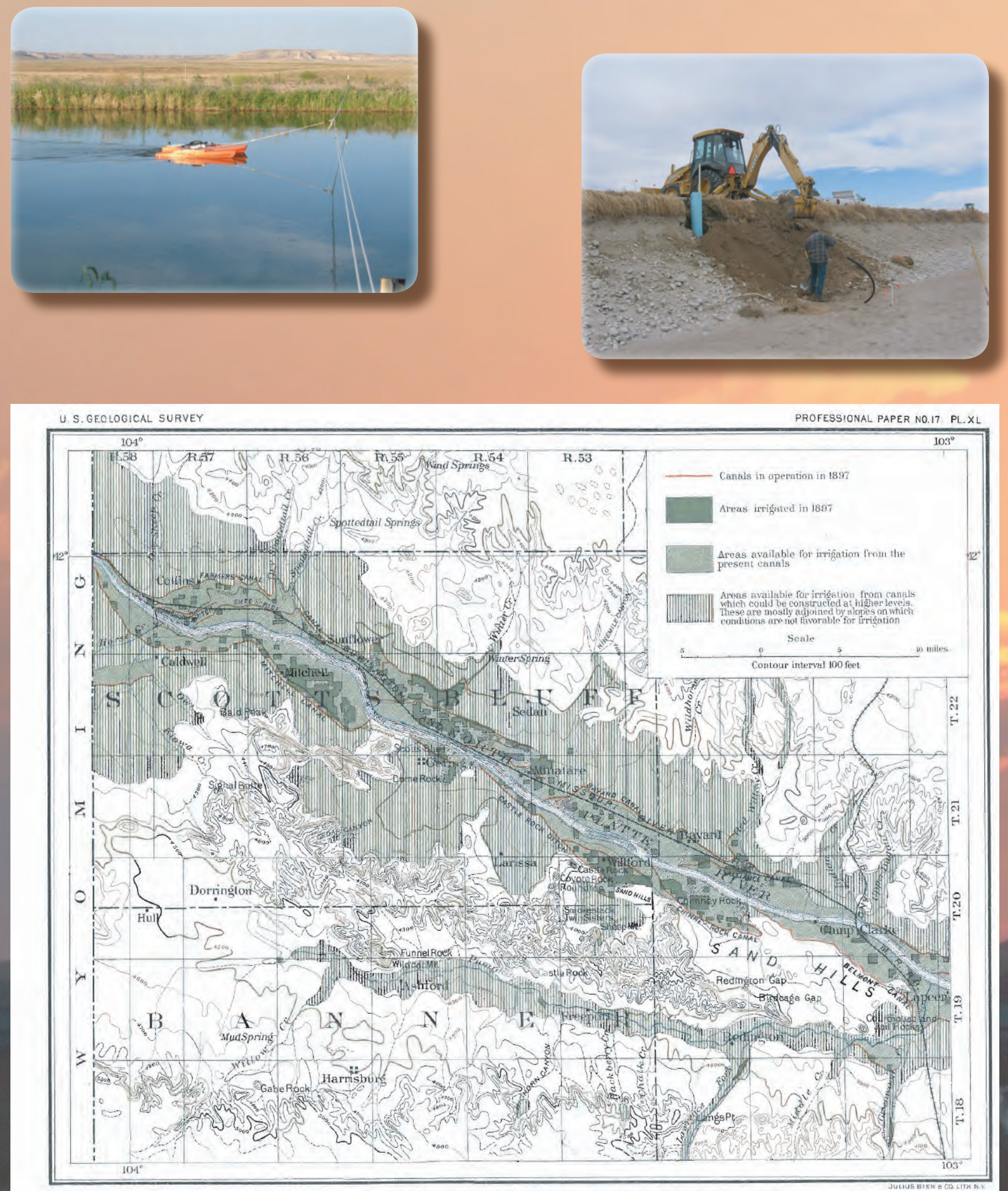

IRRIGATION MAP OF NEBRASKA WEST OF THE 103D MERIDLAN 